\title{
A Brief Overview of Potential Treatments for Viral Diseases Using Natural Plant Compounds: The Case of SARS-Cov
}

\author{
Rambod Abiri ${ }^{1}\left(\mathbb{D}\right.$, Hazandy Abdul-Hamid 1,2,*(D), Oksana Sytar 3,4 ${ }^{\mathbb{D}}$, Ramin Abiri ${ }^{5,6}$, \\ Eduardo Bezerra de Almeida, Jr. ${ }^{7}$, Surender K. Sharma ${ }^{8} \mathbb{D}$, Victor P. Bulgakov ${ }^{9, *} \mathbb{D}$, Randolph R. J. Arroo ${ }^{10}$ \\ and Sonia Malik 11,12,*(D)
}

check for updates

Citation: Abiri, R.; Abdul-Hamid, H.; Sytar, O.; Abiri, R.; Bezerra de Almeida, E., Jr.; Sharma, S.K.; Bulgakov, V.P.; Arroo, R.R.J.; Malik, S. A Brief Overview of Potential Treatments for Viral Diseases Using Natural Plant Compounds: The Case of SARS-Cov. Molecules 2021, 26, 3868. https://doi.org/10.3390/ molecules 26133868

\section{Academic Editors:}

Eduardo Sobarzo-Sánchez and Esra Küpeli Akkol

Received: 5 March 2021

Accepted: 3 June 2021

Published: 24 June 2021

Publisher's Note: MDPI stays neutral with regard to jurisdictional claims in published maps and institutional affiliations.

Copyright: (c) 2021 by the authors. Licensee MDPI, Basel, Switzerland. This article is an open access article distributed under the terms and conditions of the Creative Commons Attribution (CC BY) license (https:/ / creativecommons.org/licenses/by/ $4.0 /)$.
1 Department of Forestry Science and Biodiversity, Faculty of Forestry and Environment, Universiti Putra Malaysia, Serdang 43400, Malaysia; rambod.abiri@gmail.com or rambod.abiri@upm.edu.my

2 Laboratory of Bioresource Management, Institute of Tropical Forestry and Forest Products (INTROP), Universiti Putra Malaysia, Serdang 43400, Malaysia

3 Educational and Scientific Center "Institute of Biology and Medicine", Department of Plant Biology, Taras Shevchenko National University of Kyiv, Volodymyrska 60, 01033 Kyiv, Ukraine; oksana.sytar@uniag.sk

4 Department of Plant Physiology, Slovak University of Agriculture Nitra, A. Hlinku 2, 94976 Nitra, Slovakia

5 Department of Microbiology, School of Medicine, Kermanshah University of Medical Sciences, Kermanshah 6718773654, Iran; rabiri@kums.ac.ir

6 Fertility and Infertility Research Center, Health Technology Institute, Kermanshah University of Medical Sciences, Kermanshah 6718773654, Iran

7 Biological and Health Sciences Centre, Laboratory of Botanical Studies, Department of Biology, Federal University of Maranhão, São Luís 65080-805, MA, Brazil; eduardo.almeida@ufma.br

8 Department of Physics, Central University of Punjab, Bathinda 151401, India; surender.sharma@cup.edu.in

9 Department of Biotechnology, Federal Scientific Center of the East Asia Terrestrial Biodiversity (Institute of Biology and Soil Science), Far Eastern Branch of the Russian Academy of Sciences, 159 Stoletija Str., 690022 Vladivostok, Russia

10 Leicester School of Pharmacy, De Montfort University, The Gateway, Leicester LE1 9BH, UK; rrjarroo@dmu.ac.uk

11 Health Sciences Graduate Program, Biological \& Health Sciences Centre, Federal University of Maranhão, São Luís 65080-805, MA, Brazil

12 Laboratoire de Biologie des Ligneux et des Grandes Cultures (LBLGC), University of Orléans, 1 Rue de Chartres-BP 6759, 45067 Orleans, France

* Correspondence: hazandy@upm.edu.my (H.A.-H.); bulgakov@ibss.dvo.ru (V.P.B.); 777soniamlik@gmail.com or sonia.malik@univ-orleans.fr (S.M.)

Abstract: The COVID-19 pandemic, as well as the more general global increase in viral diseases, has led researchers to look to the plant kingdom as a potential source for antiviral compounds. Since ancient times, herbal medicines have been extensively applied in the treatment and prevention of various infectious diseases in different traditional systems. The purpose of this review is to highlight the potential antiviral activity of plant compounds as effective and reliable agents against viral infections, especially by viruses from the coronavirus group. Various antiviral mechanisms shown by crude plant extracts and plant-derived bioactive compounds are discussed. The understanding of the action mechanisms of complex plant extract and isolated plant-derived compounds will help pave the way towards the combat of this life-threatening disease. Further, molecular docking studies, in silico analyses of extracted compounds, and future prospects are included. The in vitro production of antiviral chemical compounds from plants using molecular pharming is also considered. Notably, hairy root cultures represent a promising and sustainable way to obtain a range of biologically active compounds that may be applied in the development of novel antiviral agents.

Keywords: bioactive compounds; coronavirus; hairy roots; herbal medicines; molecular farming; plant extracts; respiratory diseases 


\section{Introduction}

Bronchitis is a respiratory disease caused by bacterial infections, viral infections, or irritant particles [1]. In response to infection, the bronchial tubes become inflamed and swollen, which may eventually result in acute respiratory arrest. Coronavirus disease-19 (Covid-19), which recently emerged as a pandemic, is an infectious respiratory disease caused by a newly discovered coronavirus. The first report of this novel coronavirus was traced back to the Huanan wholesale seafood market in Wuhan city, China, in December 2019, where a group of patients exhibited a mysterious kind of viral pneumonia [2]. Nowadays, viral pneumonia is diagnosed through analyzing a sample of bronchoalveolar lavage fluid using PCR, cell cultures, and whole-genome sequencing [3]. The virus was isolated from infected individuals and recognized as genus beta-coronavirus, placing it alongside other viruses causing Severe Acute Respiratory Syndrome (SARS) and Middle East Respiratory Syndrome (MERS) [4]. Previously, SARS had been reported in Southern China during 2002-2003, and its outbreak has been reported in 29 countries, with almost 8000 infected cases and around 700 mortalities (http:/ /www.who.int/csr/sars/en/, the accessed date: 7 February 2021). A decade after the appearance of SARS, MERS was reported during 2012-2014 as a second coronavirus generation that caused a global pandemic. MERS affected people in more than 27 countries with over 2000 (32.97\%) case-fatality. Coronavirus is an enveloped, positive-sense, and single-stranded RNA or (+) ssRNA virus with a large genome of approximately $30 \mathrm{~kb}$.

Covid-19 is a life-threatening illness with a tremendous rate of spreading in humans due to its high level of infectiousness [5]. The treatment of this disease is a great challenge due to several reasons, including the rapid emergence of mutant strains, the consequent high rate of virus adaptation, and the development of resistance to antiviral medicines. Another factor is that of unwanted side effects and the high cost of synthetic antiviral drugs. There has been a significant global interest in developing safe and effective Covid-19 vaccines since 2020. Forman and his colleagues provided an overview of current phase II/III, III, and IV COVID-19 vaccine candidates (20 different vaccines) [6]. The standard approach for viral infections comprises antiviral medicines that do not cause damage to the human host but can help shorten viral infection, inhibit virus expansion, and help in reducing/blocking complications [1]. In parallel with the generation of vaccines in 2020, studies on the antiviral properties of natural compounds have also been performed via the molecular docking methodology [7-10]. The potency of marine natural products has been confirmed to target SARS-CoV-2 main protease (Mpro) [11].

Medicinal plants have been identified as reliable resource against several diseases for millennia. More than $70 \%$ of the global population still depends on herbal medicines due to their relatively low cost and better compatibility with the human body compared to synthetic drugs [12]. During the pandemic period, studies were performed using databases of scientific literature to screen and identify the potential of herbal plants to act as anticoronavirus medication [13]. It has been reported that water and ethanol plant extracts contain biologically active substances with antiviral activity [14].

A wide range of compounds identified in several plant species have demonstrated antiviral activities, including alkaloids, flavonoids, triterpenes, anthraquinones, and lignans. Interestingly, plant selection based on ethnomedical concerns provides a higher hit rate than screening plants or general synthetic products [15]. For instance, lycorine extracted from Lycoris radiata L. and glycyrrhizin from Glycyrrhiza uralensis Fisch showed anti-SARS-CoV activities [16]. Some known pharmacophore structures of bioactive substances may be useful in the creation of new anti-Covid-19 drugs. Natural compounds such as betulinic acid, indigo, aloe emodin, luteolin, quinomethyl triterpenoids, quercetin, and gallates have been reported to inhibit viral proteases with the potential to develop antiviral drugs [14]. In addition, plants have also been introduced as a safe and reliable bioreactor for the production of recombinant virus proteins that can be used in vaccine development [17], e.g., nuclear transformed tomatoes and tobacco-expressing antigens have been reported to induce immunogenic responses against SARS-CoV [18]. 
The main objective of the current review is to provide the complete overview of the ethnomedicinal uses of herbs employed to treat respiratory diseases. We address questions regarding the potential of plant-derived compounds in inhibiting virus propagation, thus providing relief for viral-induced pathogenesis. We also discuss how biotechnology may help solve the challenge of rapidly obtaining pure antiviral compounds. Furthermore, this review discusses the current state of the art regarding the possible antiviral activities of herbal medicine and makes an effort to tackle the gaps in scientific knowledge that may lead to the advancement of innovative treatments for the welfare of people and against the spread of viral diseases, especially SAR-CoV.

\section{A Brief Model of Viral Entering/Replication in Host Cells}

The life and replication cycle of a virus is dependent on the cell processes of its host (Figure 1). The reproduction cycle of viruses causes significant structural (cytopathic) and biochemical damage that, in severe conditions, may ultimately result in the death of the host organism [19]. Viruses can enter host cells via different biological mechanisms including phagocytosis, pinocytosis, and endocytosis. To enter and spread to the cells of a living organism, the virus fuses at the plasma membrane in the first phase, and then it infects the other cells of the host organism via cell-to-cell syncytia or fusion in the second phase. The respiratory system is the main site of entrance for viruses into host organisms, and severe infection of the respiratory tract may cause life-threatening damage to the lungs [20]. Generally, viral replication is completed within several hours [21] and involves various phases including attachment, penetration, un-coating, replication, assembly, and release [22].

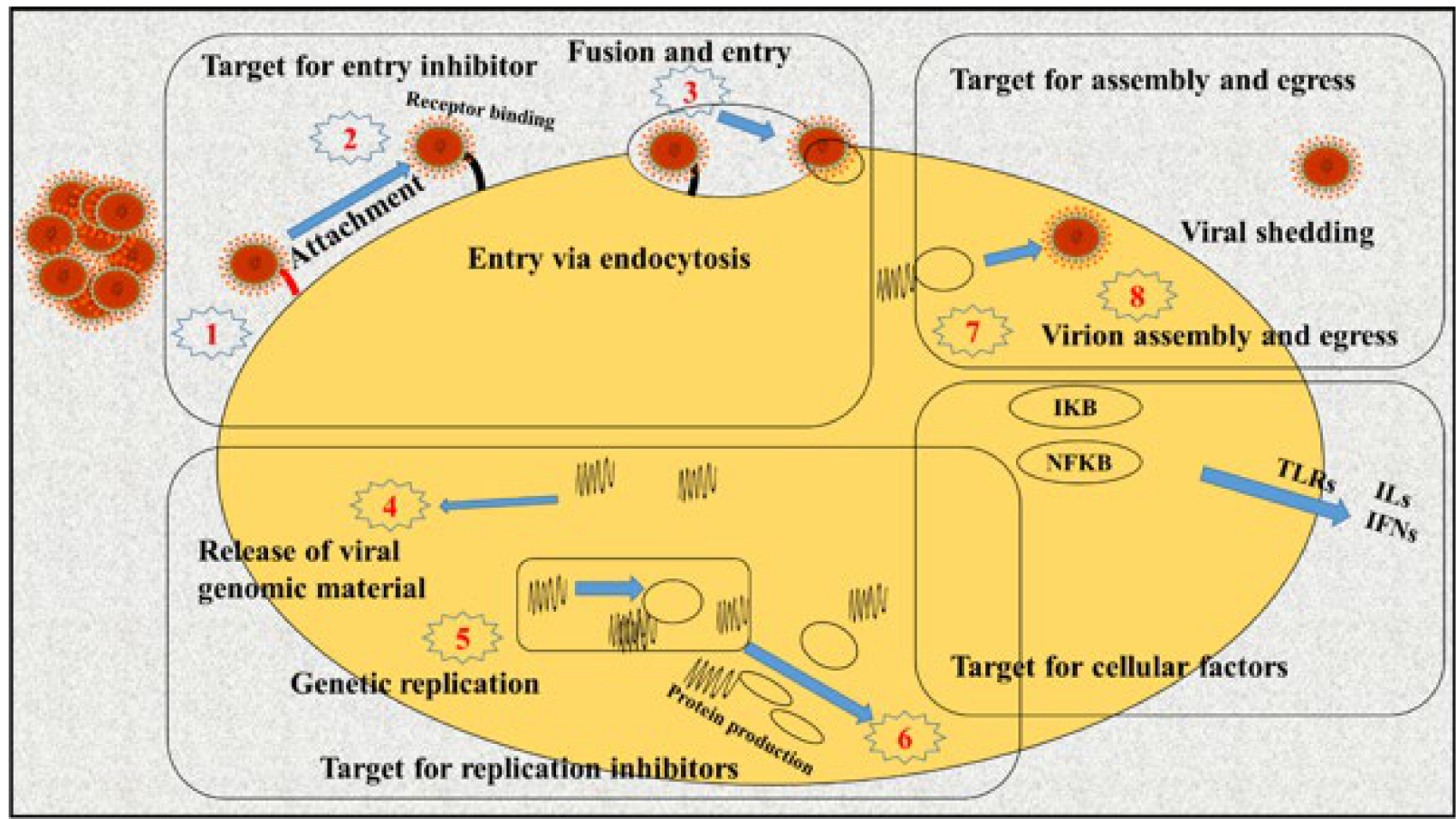

Figure 1. The most important viral replication chain includes virus attack to the host cell (Steps 1-3); entry using receptor bindings (Steps 1 and 4-6); and mRNA transcription/replication, and protein translation, and assembly and budding of progeny virus particles (Steps 1, 7, and 8). These steps are the most important goals for viral polymerase inhibition, replication (e.g., protease inhibitors, inhibitors of entry, and integrate inhibitors, among others), budding, and assembly [23].

\section{General Model of SARS-CoV Pathogenicity}

Coronaviruses (CoVs) are considered as a subfamily of Orthocoronavirinae and belongs to a cluster of vertebrate animal and human viruses that affect the respiratory tract, liver, central nervous systems, and digestive systems [24]. Currently, no specific anti-viral 
treatment has been recommended for COVID-19, and investigations have focused on vaccine development [25]. This human pathogen is a positive-strand RNA virus (positivesense ( $5^{\prime}$-to- $\left.3^{\prime}\right)$ viral RNA) enveloped by spike glycoproteins (S). These proteins bind to their receptor on the surface of the host cells. The spike proteins possess two compartments, namely envelop proteins (E) and membrane proteins (M), which play important roles in pathogenesis. Some spike glycoproteins have envelope-associated hemagglutinin-esterases (HEs) [26]. CoVs can bind to angiotensin-converting enzyme (ACE2) receptors through the receptor-binding domain (RBD) and then enter cells. The virus has two different shapes, $\mathrm{L}$ and S. The "L" from is assumed to be more virulent and adaptable than the "S" form to interact with the [27]. Specifically, the S1 domain of Covid-19's spike glycoprotein interacts with an immunoregulatory factor for virulence and hijacking, the human CD26 [28]. CD26 is linked to inflammation; it plays a vital function in T-cell activation and is expressed in plasma and on the cell surface of several non-immune and immune cell types. It has been reported that high-fiber diets and citrus flavonoids that ameliorate the effects of type 2 diabetes mellitus (T2DM) are also inhibitors of CD26 [20].

Furthermore, the epigenetic dysregulation of ACE2 and interferon-regulated genes may suggest increased Covid-19 susceptibility and severity in lupus patients [29]. The $S$ protein has two functional domains: (a) the receptor-binding domain and (b) sequences that mediate the fusion of viral and cell membranes. S-glycoprotein must be cleaved by cellular proteases to provide access to fusion sequences and is required for cell entry. The nature of the cell protease that cleaves the $S$ glycoprotein varies according to the coronavirus type. For instance, the MERS-CoV S glycoprotein contains a furin protease cleavage site and is processed by these intracellular proteases during exit from the cell. This protein processing by the host's furin protease is necessary for the development of the virus and allows it to enter the next cell. In contrast, SARS-CoV S glycoprotein is uncleaved upon release of virus from cells. It is probably cleaved during virus entry into a cell. Furin proteases may therefore be targeted for therapeutic uses [20] (Figure 2).

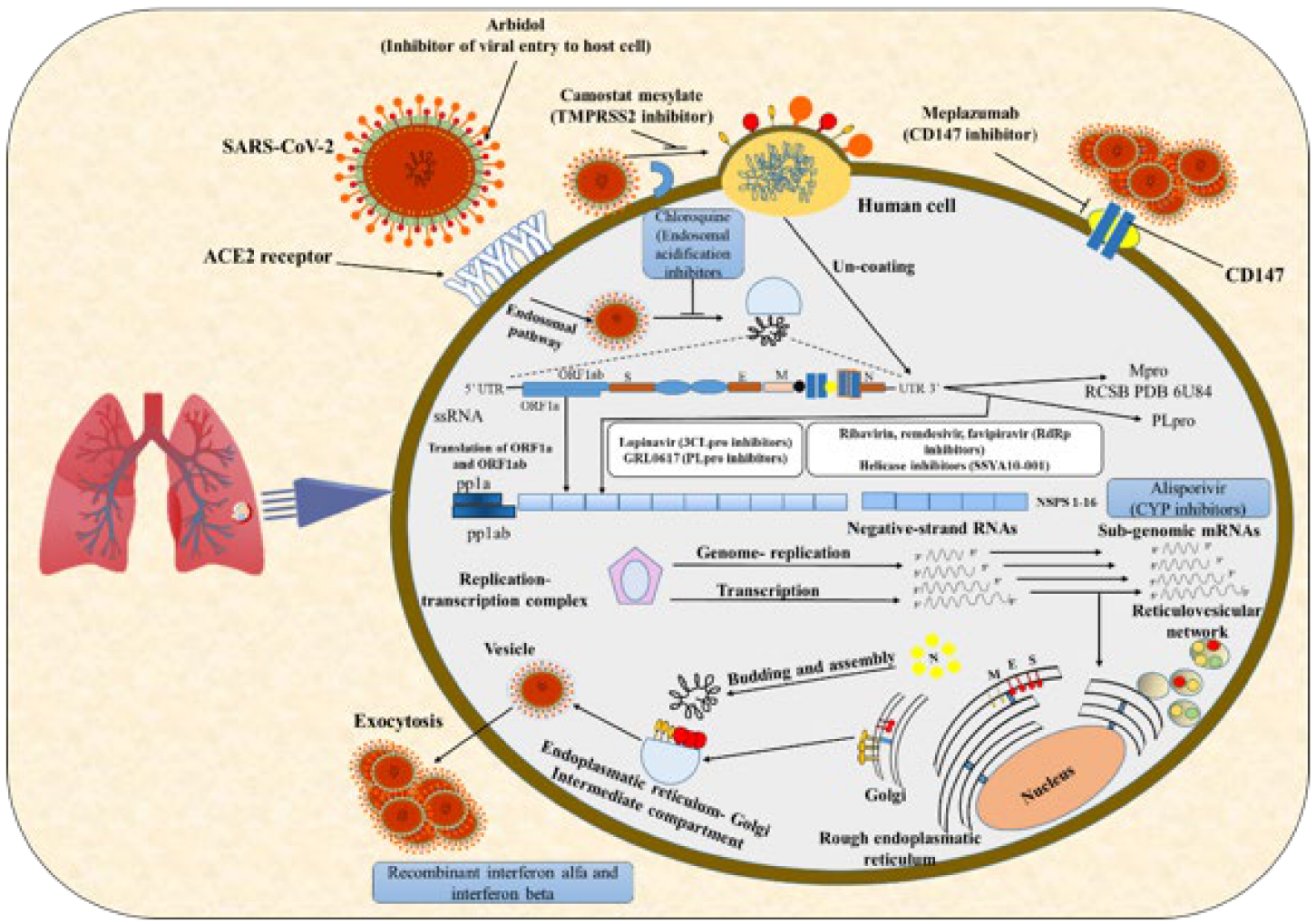

Figure 2. The replication cycle of SARS-CoV-2 and its inhibitors. The binding of the spike (S) protein to the host cell receptor initiates SARS-CoV-2 infection. SARS-CoV-2 has so far been linked to two cellular receptors: angiotensin-converting enzyme 2 (ACE2) and CD147. The cleavage of the S protein by the cell surface-associated enzyme occurs after receptor engagement. 
The viral genomic RNA is translated through ribosomal frameshifting to produce the polyproteins pp1a and pp1ab, which are co-translationally proteolytically processed into the 15 non-structural proteins (nsp1-nsp10 and nsp12-nsp16) that make up the replication-transcription complex (RTC). The RTC is involved in the replication of genomic RNA and the transcription of a series of nested subgenomic mRNAs that are essential for the expression of structural and accessory protein genes. New virions are formed by budding into the intracellular membranes of the ER-Golgi intermediate compartment membranes and then being released via exocytosis. In addition, blue denotes the extensive host-based therapy choices, and pink denotes specific viral-based treatment possibilities [30].

\section{Replication Inhibitors of SARS-CoV}

Previous investigations have demonstrated that the development of proteases is an ideal goal to be tackled for the inhibition of $\mathrm{CoV}$ replication. In silico analysis demonstrated a $96 \%$ similarity between $2019-\mathrm{CoV}$ main protease and the SARS-CoV Mpro, and no mutation was reported in the active sites in both proteins [31]. Though the protease activity disruption causes various diseases, host proteases are considered reliable therapeutic targets. For several different viruses, protease activity represents a vital factor in replication; thus, proteases are frequently targeted as protein candidates during antiviral therapeutics studies [32]. Lopinavir and nelfinavir are in the category of medications named protease inhibitors with a high level of cytotoxicity recommended for the treatment of cells infected with MERS, SARS, and HIV [33]. Some preliminary investigations have examined the potential of protease inhibitor ritonavir/lopinavir, which is regularly implemented to cure human immunodeficiency virus (HIV)/acquired immunodeficiency syndrome cases for the therapy of Covid-19-infected patients. In addition, other studies on the antiviral treatment of pathogenic forms of human CoV have reported on lamivudine (3TC), tenofovir disoproxil (TDF), umifenovir (arbidol), remdesivir, neuraminidase inhibitors, and nucleoside analogues, among others [34]. Moreover, another effort demonstrated that nelfinavir was the best potential inhibitor candidate over praziquantel, perampanel, and pitavastatin against COVID-19 Mpro. The efficiency of nelfinavir has been reported due to the binding free energy calculations using the molecular mechanics with generalized Born and surface area solvation (MM/GBSA) model and solvated interaction energy (SIE) methods. In this regard, the crystal structures of protease/chymotrypsin-like protease $\left(3 \mathrm{CL}^{\mathrm{pro}}\right)$ [27] from Covid-19 patients have shown that this protease could have the capability to inhibit CoV replication [35]. On the other hand, molecular docking investigations revealed that epicatechin-gallate, catechin, curcumin, oleuropein, apigenin-7-glucoside, demethoxycurcumin, and luteolin-7-glucoside may have the potential to inhibit Covid-19 Mpro. Additionally, an in silico analysis showed that the mentioned phenolic compounds share a pharmacophore with nelfinavir [36]. Thus far, different flavonoid compounds derived from medicinal plants have shown antiviral bioactivities for inhibiting protease.

\section{Inhibitors of Assembly and Packaging of SARS-CoV}

During the virus' life cycle, the assembly and release of infectious particles is the final phase [37]. In this phase, viral structural proteins (often mentioned as pre-structural proteins such as P1 of enterovirus 71) mature until they are assembled into viral capsids. In this phase, the SARS-CoV genomes are actively tightly packaged into pre-formed viral protein capsids for enveloped intracellular cargo transport and then released [38]. Notwithstanding the absolute necessity for virus infection, so far, no antiviral drugs/agents have tackled this phase [39]. However, the results of studies have shown that some medicinal plants can interfere with the viral packaging and assembly mechanisms [23].

\section{Evidence Supporting the Antiviral Efficacy of Medicinal Plants}

The use of therapeutic plants against viral infection can be traced back to the dawn of civilization; however, BOOTS Pure Drug Co., Ltd., Nottingham (England) made the first systematic effort to screen plants against influenza [40]. Later on, the inhibitory effect of medicinal plants on the replication of viruses was studied on severe acute respiratory syndrome (SARS) virus, emerging viral infections linked with poxvirus, hepatitis B virus 
(HBV), HIV, and herpes simplex virus type 2 (HSV-2) [41-46] (Table 1). Many studies have applied either alcoholic or aqueous extracts of medicinal plants. However, only a few investigations have been conducted to study active natural compounds presenting antiviral effects. It has been demonstrated that molecular mechanisms linked to the antiviral effects of medicinal plant extracts vary among various types of viruses. Nonetheless, medicinal plant extracts potentially improve the inherent antiviral defense mechanisms of the human body, which involve a complicated system and might use several concurrent pathways. Thus far, some investigations have discovered immunostimulatory properties of medicinal plant extracts possessing antiviral activity [47]. Many plants including Vitex negundo, Solanum nigrum, Scharicum guerke, Ocimum kilim, Sambucus ebulus, Ocimum sanctum, Euphorbia granulate, Eugenia jambolana, and Acacia nilotica have been revealed to target reverse transcriptase activity and have shown inhibitory actions towards HIV proteases [48-53]. The root extracts of Heracleum maximum Bartr. (Apiaceae) enhanced interleukin 6 (IL-6) in a macrophage activation test, thus proving antiviral effects linked with the immunostimulatory characteristics [47]. Likewise, Plantago asiatica Linn. (Plantaginaceae) and Plantago major Linn. are frequently used as folk medicinal plants in Taiwan for the treatment of different infectious diseases, and both were found to induce the secretion of interferon-gamma (IFN- $\gamma$ ) and lymphocyte proliferation at low concentrations. Both the secretion of interferon-gamma (IFN- $\gamma$ ) and the induction of lymphocyte proliferation activity are reliable indicators of cell-mediated immune response modulation [47,54].

Table 1. Example of biological active agents extracted from medicinal plants against SARS-CoV and other virus infections.

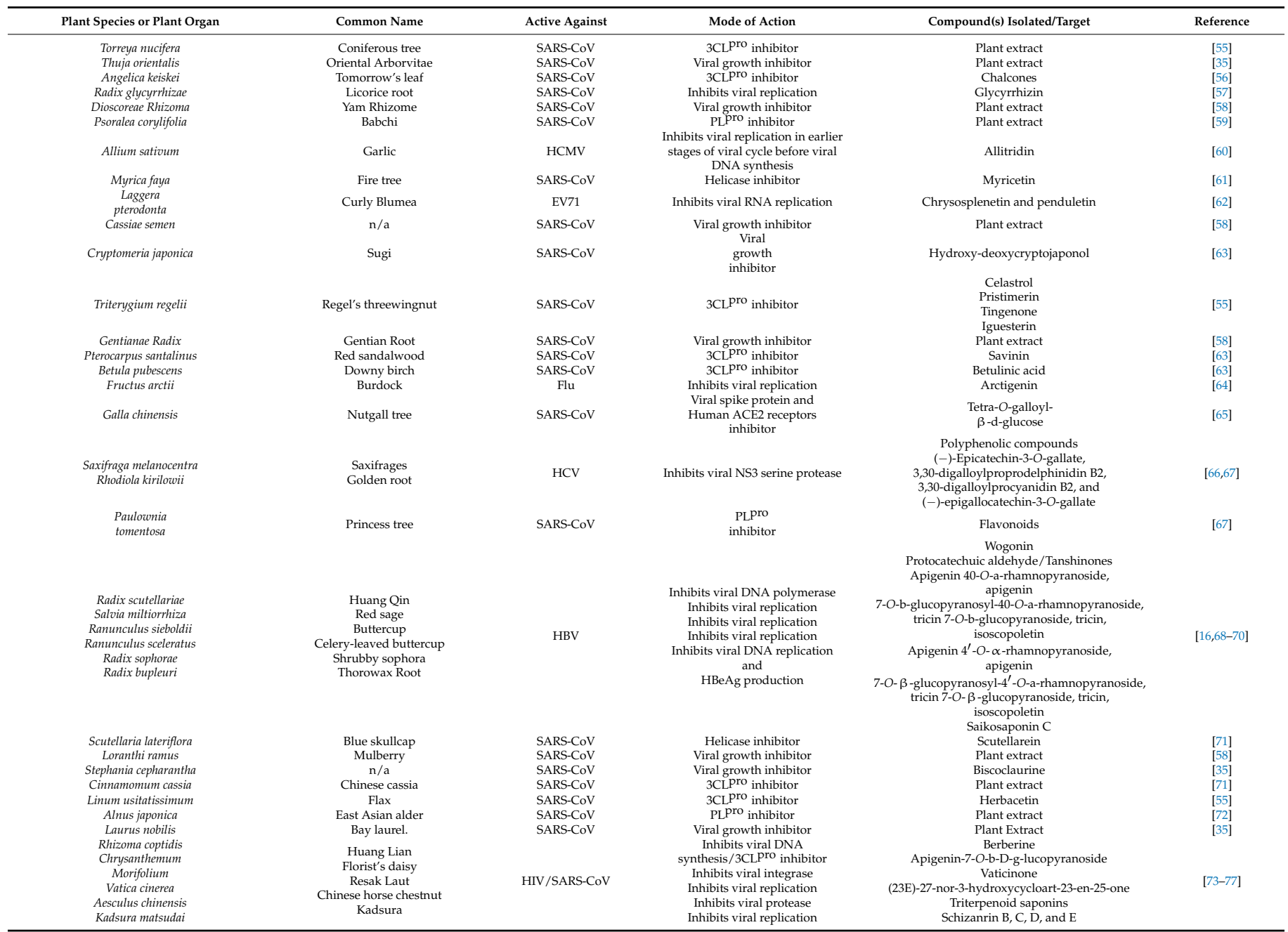


Table 1. Cont.

\begin{tabular}{|c|c|c|c|c|c|}
\hline Plant Species or Plant Organ & Common Name & Active Against & Mode of Action & Compound(s) Isolated/Target & Reference \\
\hline & & & & $\begin{array}{l}\text { Yatein } \\
\text { Putranjivain A }\end{array}$ & \\
\hline & & & Inhibits HSV-1 ICP0, ICP4 & Samarangenin B & \\
\hline Chamaecyparis obtuse & $\begin{array}{l}\text { Hinoki cypress } \\
\text { Spurge }\end{array}$ & & expression, & Protocatechuyl aldehyde & \\
\hline & $\begin{array}{l}\text { Spurge } \\
\text { Girard }\end{array}$ & & $\begin{array}{l}\text { and as viral DNA synthesis } \\
\text { Affects the late stage of HSy-2 }\end{array}$ & Isodihydrosyringetin, (-)-epigallocatechin & \\
\hline $\begin{array}{l}\text { Limonum simense } \\
\text { Ranunculus sieboldii }\end{array}$ & $\begin{array}{l}\text { Girard } \\
\text { Buttercup }\end{array}$ & HSV & & $\begin{array}{c}\text { 3-O-gallate, } \\
\text { samarangenin B, myricetin, myricetin }\end{array}$ & {$[16,78-81]$} \\
\hline $\begin{array}{l}\text { Ranunculus sceleratus } \\
\text { Limonium sinense }\end{array}$ & $\begin{array}{c}\text { Celery-leaved buttercup } \\
\text { Girard }\end{array}$ & & $\begin{array}{l}\text { Inhibits viral replication } \\
\text { Inhibits viral replication } \\
\text { Inhibits viral replication }\end{array}$ & $\begin{array}{c}\text { 3- } \alpha \text {-arhamnopyranoside, } \\
\text { quercetin 3-O- } \alpha \text {-rhamnopyranoside, } \\
(-) \text {-epigallocatechin, } \\
\text { gallic acid, N-trans-caffeoyltyramine, } \\
\text { N-transferuloyltyramine }\end{array}$ & \\
\hline Azadirachta indica & Neem tree & Dengue virus & $\mathrm{n} / \mathrm{a}$ & $\begin{array}{l}\text { Leaf extract (Aqueous) } \\
\text { inhibits DEN-2 in vivo } \\
\text { Leaves used to inhibit }\end{array}$ & [82] \\
\hline Moringa oleifera & Horseradish tree & $\begin{array}{l}\text { HIV/Epstein-Barr virus } \\
\text { (EBV) }\end{array}$ & $\mathrm{n} / \mathrm{a}$ & $\begin{array}{c}\text { viral replication/leaves and seeds inhibits } \\
\text { activity against EBV } \\
\text { activation }\end{array}$ & {$[83,84]$} \\
\hline Terminalia bellerica & Myrobalan & $\begin{array}{c}\text { HIV-1 } \\
\text { Pseudo viruses }\end{array}$ & $\mathrm{n} / \mathrm{a}$ & $\begin{array}{c}\text { Plant extract against } \\
\text { HIV-1 }\end{array}$ & [85] \\
\hline Rheum palmatum & Chinese rhubarb & SARS-CoV & Viral spike protein and & Emodin & [86] \\
\hline $\begin{array}{l}\text { Avicennia marina } \\
\text { Litchi chinensis }\end{array}$ & $\begin{array}{l}\text { Grey mangrove } \\
\text { litchi }\end{array}$ & $\begin{array}{l}\text { Hepatitis B virus } \\
\text { SARS-CoV }\end{array}$ & $\begin{array}{l}\text { Inhibits HBV antigen } \\
3 \mathrm{CL}^{\text {pro }} \text { inhibitor }\end{array}$ & $\begin{array}{c}n / \mathrm{a} \\
\text { Flavonoids extract }\end{array}$ & $\begin{array}{l}{[87]} \\
{[52]}\end{array}$ \\
\hline Multiflora Tuber & Tuber fleeceflower & SARS-CoV & $\begin{array}{l}\text { Viral spike protein and } \\
\text { Human ACE receptors inhibitor }\end{array}$ & Emodin & [86] \\
\hline Canthium coromandelicum & Alston & HIV & 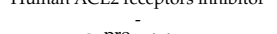 & Leaf extract controls HIV infection & [82] \\
\hline Houttuynia cordata & Fish mint & SARS-CoV & $\begin{array}{l}\text { 3CL Pro inhibitor } \\
\text { and RNA-dependent } \\
\text { RNA polymerase (RdRp) } \\
\text { inhibitor }\end{array}$ & Plant extract & [88] \\
\hline Veronica linariifolia & Speedwell & SARS-CoV & $\begin{array}{l}\text { Viral growth inhibitor } \\
\text { Exhibits anti-HSV-1 and -2 }\end{array}$ & Luteolin & [62] \\
\hline Carissa edulis & Conkerberry & Herpes simplex virus & $\begin{array}{l}\text { properties in vitro and in vivo } \\
\text { strongly }\end{array}$ & $\mathrm{n} / \mathrm{a}$ & [89] \\
\hline Nicotiana benthamiana & $\begin{array}{l}\text { Benth } \\
\text { Common nettle }\end{array}$ & SARS-CoV & $\begin{array}{l}\text { Viral growth inhibitor } \\
\text { Virot }\end{array}$ & NICTABA Lectin & {$[90]$} \\
\hline Phyllanthus amarus & Indian gooseberry & $\begin{array}{c}\text { SARS-CoV } \\
\text { Human } \\
\text { immunodeficiency } \\
\text { virus/hepatitis B virus }\end{array}$ & Viral spike protein inhibitor & $\begin{array}{l}\text { Urtica dioica agglutinin } \\
\text { Plant extract had lost } \\
\text { HBV antigen surface }\end{array}$ & [92] \\
\hline Guazuma ulmifolia Lam & West Indian elm & Polio virus & $\begin{array}{l}\text { Extracts inhibits polio } \\
\text { replications }\end{array}$ & $\mathrm{n} / \mathrm{a}$ & [93] \\
\hline Achyranthus aspera & Chaff-flower & $\begin{array}{c}\text { Herpes } \\
\text { simplex virus }\end{array}$ & $\begin{array}{l}\text { Inhibits earlier stages of } \\
\text { HSV multiplications }\end{array}$ & $\mathrm{n} / \mathrm{a}$ & [94] \\
\hline Camelliasinensis & Tea tree & SARS-CoV & $3 \mathrm{CL}^{\text {pro }}$ inhibitor & Tannic acid/3-isotheaflavin-3-gallate & [95] \\
\hline Sesbania grandiflora & Vegetable hummingbird & Herpes simplex virus & $\mathrm{n} / \mathrm{a}$ & $\begin{array}{l}\text { Extract possesses strong } \\
\text { antiviral activity against HSV }\end{array}$ & [96] \\
\hline Ficus religiosa & Bo tree & $\begin{array}{l}\text { Human rhino virus } \\
\text { (HRV) and Respiratory } \\
\text { syncytial virus (RSV) }\end{array}$ & S: ifin & $\begin{array}{l}\text { Bark extract endowed } \\
\text { with antivirus activity } \\
\text { against HRV and RSV }\end{array}$ & [97] \\
\hline Hippophae rhamnoides & & Dengue virus & $\begin{array}{l}\text { Significant anti-dengue } \\
\text { activity }\end{array}$ & Leaf extract & [98] \\
\hline Glycine max(black) & Soybean & $\begin{array}{c}\text { Human adenovirus } \\
\text { (type } 1)\end{array}$ & $\begin{array}{l}\text { Inhibits human ADV-1 in } \\
\text { dose-dependent manner }\end{array}$ & $\mathrm{n} / \mathrm{a}$ & [99] \\
\hline Acacia nilotica & Gum arabic tree & HIV-PR & $\begin{array}{l}\text { Inhibition } \\
\text { Col }\end{array}$ & $\mathrm{n} / \mathrm{a}$ & [100] \\
\hline Allium sativum & Garlic & SARS & $\begin{array}{l}\text { Proteolytic and hemagglutinating } \\
\text { activity and } \\
\text { viral replication }\end{array}$ & $\mathrm{n} / \mathrm{a}$ & [101] \\
\hline $\begin{array}{l}\text { Andrographis paniculata } \\
\text { Boerhaavia diffusa }\end{array}$ & $\begin{array}{l}\text { Green chireta } \\
\text { Punarnava }\end{array}$ & $\begin{array}{l}\text { SARS-COV and likely } \\
\text { SARS-CoV-2 }\end{array}$ & $\begin{array}{l}\text { Suppression } \\
\text { Inhibition }\end{array}$ & $\begin{array}{l}\text { NLRP3, capase- } 1 \text {, and IL-1 } \beta \\
\text { ACE }\end{array}$ & {$[31,102,103]$} \\
\hline Clerodendrum inerme & The glory bower & SARS-CoV-2 & Inactivation & Ribosome & [104] \\
\hline Clitoria ternatea & Butterfly pea & $\mathrm{n} / \mathrm{a}$ & Metalloproteinase inhibitor & ADAM17 & [105] \\
\hline Coriandrum sativum & Coriander & $\mathrm{n} / \mathrm{a}$ & Inhibition & $\mathrm{ACE}$ & [106] \\
\hline $\begin{array}{l}\text { Cynara scolymus } \\
\text { Cassia occidentalis }\end{array}$ & Scolymus & $\mathrm{n} / \mathrm{a}$ & Inhibition & $\mathrm{ACE}$ & {$[102,103]$} \\
\hline Embelia ribes & White-flowered Embelia & $\mathrm{n} / \mathrm{a}$ & Inhibition & ACE & {$[102,103]$} \\
\hline $\begin{array}{l}\text { Eugenia jambolana } \\
\text { Euphorbia granulata }\end{array}$ & $\begin{array}{l}\text { Black Plum } \\
\text { Asthma-plant }\end{array}$ & $\begin{array}{l}\text { n/a } \\
\text { HIV-1 PR }\end{array}$ & $\begin{array}{l}\text { Inhibition } \\
\text { Inhibition }\end{array}$ & Protease & $\begin{array}{c}{[49]} \\
{[100]}\end{array}$ \\
\hline $\begin{array}{l}\text { Glycyrrhiza glabra } \\
\text { Gymnema sylvestre }\end{array}$ & $\begin{array}{l}\text { Licorice } \\
\text { Gurmar }\end{array}$ & SARS; HIV-1 & $\begin{array}{l}\text { Inhibition of viral replication; } \\
\text { modulation of membrane fluidity } \\
\text { Inhibition of viral DNA synthesis }\end{array}$ & Glycyrrhizin & {$[57,107]$} \\
\hline Hyoscyamus niger & black henbane & $\mathrm{n} / \mathrm{a}$ & Inhibition and Bronchodilator & $\mathrm{Ca}^{2+}$ & [108] \\
\hline $\begin{array}{l}\text { Ocimum } \\
\text { kilimandscharicum }\end{array}$ & Camphor basil & HIV-1 & Inhibition & $\mathrm{n} / \mathrm{a}$ & [51] \\
\hline $\begin{array}{l}\text { kilimandscharicum } \\
\text { Ocimum sanctum }\end{array}$ & Holy basil & HIV-1 & Inhibition & $\mathrm{n} / \mathrm{a}$ & [50] \\
\hline Punica granatum & Pomegranate & Human herpes virus-3 & Inhibition & $\begin{array}{l}\text { ACE/Phytochemical extract } \\
\text { exhibits potential antiviral activity }\end{array}$ & {$[102,103]$} \\
\hline $\begin{array}{l}\text { Salacia oblonga } \\
\text { Sambucus ebulus } \\
\text { Solanum nigrum }\end{array}$ & $\begin{array}{c}\text { Oblong leaf salacia } \\
\text { Danewort } \\
\text { European black nightshade }\end{array}$ & $\begin{array}{c}\mathrm{n} / \mathrm{a} \\
\text { Enveloped virus } \\
\text { HIV-1 }\end{array}$ & $\begin{array}{l}\text { Suppression } \\
\text { Inhibition } \\
\mathrm{n} / \mathrm{a}\end{array}$ & $\begin{array}{c}\text { Angiotensin II and AT1 } \\
\mathrm{n} / \mathrm{a} \\
\mathrm{n} / \mathrm{a}\end{array}$ & $\begin{array}{c}{[109]} \\
{[110]} \\
{[52]}\end{array}$ \\
\hline Sphaeranthus indicus & East Indian globe & Mouse corona virus and & Inhibition & $\mathrm{n} / \mathrm{a}$ & {$[111,112]$} \\
\hline Strobilanthes callosa & Plietesials & HCoV-NL63 & Blocking & $\mathrm{n} / \mathrm{a}$ & {$[107,113]$} \\
\hline Strobilanthes cusia & Kuntze & HCoV-NL63 & Blocking & $\mathrm{n} / \mathrm{a}$ & [113] \\
\hline Vitex negundo & Five-leaved chaste tree & HIV-1 & Inhibition & $\mathrm{n} / \mathrm{a}$ & {$[52,53,113,114]$} \\
\hline Emblica officinalis & Emblic & Influenza A virus & $\begin{array}{l}\text { Prevention of virus adsorption } \\
\text { and suppression f virus release }\end{array}$ & Pentagalloyl glucose & [114] \\
\hline Vitex trifolia & Simpleleaf Chastetree & SARS-COV & Reduction & $\mathrm{n} / \mathrm{a}$ & [115] \\
\hline
\end{tabular}

\section{Plant-Derived Immunomodulators}

The phagocyte-microbe interactions in the immune system comprise a defense reaction that, under more harmful circumstances, may take part in the advancement of various immune and non-immune chronic inflammatory diseases. The immune system of a healthy organism manages the homeostasis of the body. Agents that express a capacity to modulate and normalize pathophysiological processes are named immunomodulators [116]. Most of the well-known immunostimulants and immunosuppressants used in clinical practice are cytotoxic drugs, which can have severe side effects. Therefore, plant-derived compounds and extracts have been studied regarding their immunomodulatory potential in 
humans due to their lower cytotoxicity and high bioavailability $[117,118]$. Plant-derived immunomodulators can also be used for a long period [119] (Table 2).

Some plant-derived compounds, e.g., curcumin, genistein, fisetin, quercetin, resveratrol, epigallocatechin-3-gallate, andrographolide, and colchicine, have immunomodulatory effects [120-126]. These compounds can downregulate the production of proinflammatory cytokines induced by some viroidal agents [122]. Andrographolide and other natural immunomodulators can enhance the activity of cytotoxic T cells, phagocytosis, natural killer (NK) cells, and antibody-dependent cell-mediated cytotoxicity [125]. The use of quercetin in combination with highly active compounds such as psoralen, baccatin III, embelin, and menisdaurin increased its anti-hepatitis B activity up to $10 \%$ [127].

At the same time, analyses of other medicinal plant extracts with antiviral properties have shown that Gymnema sylvestre [121], Stephania tetrandra S Moore roots [128-130], and Vitex trifolia extracts [107] possess immunomodulating activity. Naser et al. [131] found immunomodulation potential and antiviral activities against acute common cold in leaf extracts of Thuja occidentalis. The anti-SARS and immunomodulatory activity of water extracts of Houttuynia cordata have been reported via the stimulation of lymphocyte proliferation together with enhancing the proportion of $\mathrm{CD}^{4+}$ and $\mathrm{CD} 8^{+\mathrm{T}}$ cells [81] (Table 3).

Table 2. Plant sources of polyphenolic compounds with anti-protease activity.

\begin{tabular}{|c|c|c|c|c|c|c|}
\hline \multirow{2}{*}{ Plant Species } & \multirow{2}{*}{ Sources } & \multirow{2}{*}{ Compounds } & \multirow{2}{*}{ Molecular Formula } & \multicolumn{2}{|c|}{ Lipinski's Rule of Five } & \multirow{2}{*}{ Reference } \\
\hline & & & & Properties & Value & \\
\hline \multirow{5}{*}{$\begin{array}{l}\text { Spinacia oleracea, } \\
\text { Brassica oleracea, Anethum } \\
\text { graveolens, Brassica rapa, } \\
\text { Sauropus androgynus }\end{array}$} & & \multirow{5}{*}{ Kaempferol } & \multirow{5}{*}{ C15H10O6 } & Molecular weight $(<500 \mathrm{Da})$ & 286.24 & \multirow{5}{*}[132,133]{} \\
\hline & $\begin{array}{l}\text { Spinach } \\
\text { Canbage }\end{array}$ & & & $\log P(<5)$ & 1.58 & \\
\hline & $\begin{array}{l}\text { Cabbage } \\
\text { Dill }\end{array}$ & & & H-bond donor (5) & 4 & \\
\hline & Chinese cabbage Katuk & & & H-bond acceptor $(<10)$ & 6 & \\
\hline & Dill & & & Violations & 0 & \\
\hline \multirow{5}{*}{$\begin{array}{c}\text { Foeniculum vulgare, Allium } \\
\text { cepa, } \\
\text { Oregano vulgare, Capsicum } \\
\text { annum }\end{array}$} & $\begin{array}{l}\text { Dill } \\
\text { Fennel leaves }\end{array}$ & \multirow{5}{*}{ Quercetin } & & Molecular weight (<500 Da) & 302.24 & \\
\hline & & & & $\log \mathrm{P}(<5)$ & 1.23 & \\
\hline & Onion & & $\mathrm{C} 15 \mathrm{H} 10 \mathrm{O} 7$ & H-bond donor (5) & 5 & [132] \\
\hline & Oregano & & & H-bond acceptor $(<10)$ & 7 & \\
\hline & Chili pepper & & & Violations & 0 & \\
\hline & Olive & & & Molecular weight $(<500 \mathrm{Da})$ & 448.38 & \\
\hline Olea europaea, Averrhoa & Star fruit & & & $\log \mathrm{P}(<5)$ & 0.16 & \\
\hline belimbi, Capsicum annum, & Chili pepper & Luteolin-7-glucoside & $\mathrm{C} 21 \mathrm{H} 20 \mathrm{O} 11$ & H-bond donor (5) & 7 & [134] \\
\hline Allium fistulosum & Welsh onion/Leek & & & H-bond acceptor $(<10)$ & 11 & \\
\hline & & & & Violations & 2 & \\
\hline & & & & Molecular weight $(<500 \mathrm{Da})$ & 338.35 & \\
\hline & & & & $\log \mathrm{P}(<5)$ & 3 & \\
\hline Curcuma longa, & Turmeric & Demethoxycurcumine & $\mathrm{C} 20 \mathrm{H} 18 \mathrm{O} 5$ & H-bond donor (5) & 2 & {$[135,136]$} \\
\hline Curcuma xanthorriza & Curcuma & & & H-bond acceptor $(<10)$ & 5 & \\
\hline & & & & Violations & 0 & \\
\hline & & & & Molecular weight $(<500 \mathrm{Da})$ & 567.78 & \\
\hline & & & & $\log P(<5)$ & 4.33 & \\
\hline Citrus sinensis & Citrus fruit & Naringenin & $\mathrm{C} 15 \mathrm{H} 12 \mathrm{O} 5$ & H-bond donor (5) & 4 & [137] \\
\hline & & & & H-bond acceptor $(<10)$ & 5 & \\
\hline & & & & Violations & 1 & \\
\hline & & & & Molecular weight $(<500 \mathrm{Da})$ & 432.34 & \\
\hline Averrhoa belimbi, Lycium & & & & $\log \mathrm{P}(<5)$ & 0.55 & \\
\hline chinese, Apium graveolens, & Goji berries & Apigenine-7-glucoside & $\mathrm{C} 21 \mathrm{H} 20 \mathrm{O} 10$ & H-bond donor (5) & 6 & [138-140] \\
\hline Olea Europaea & Celery & 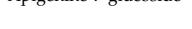 & - & H-bond acceptor $(<10)$ & 10 & \\
\hline & & & & $\begin{array}{l}\text { Violations } \\
\text { 1-div) }\end{array}$ & 1 & \\
\hline & & & & Molecular weight $(<500 \mathrm{Da})$ & 378.37 & \\
\hline & & & & $\log \mathrm{P}(<5)$ & 1.57 & \\
\hline Olea Europaea & Olive & Oleuropein & $\mathrm{C} 19 \mathrm{H} 22 \mathrm{O} 8$ & H-bond donor (5) & 3 & [138] \\
\hline & Give & & & H-bond acceptor $(<10)$ & 8 & \\
\hline & & & & Violations & 0 & \\
\hline & & & & Molecular weight $(<500 \mathrm{Da})$ & 290.27 & \\
\hline & & & & $\log \mathrm{P}(<5)$ & 0.85 & \\
\hline Camellia sinesis & Green tea & Catechin & $\mathrm{C} 15 \mathrm{H} 14 \mathrm{O} 6$ & H-bond donor (5) & 5 & {$[141,142]$} \\
\hline & & & & H-bond acceptor $(<10)$ & 6 & \\
\hline & & & & Violations & 0 & \\
\hline & & & & Molecular weight $(<500 \mathrm{Da})$ & 368.38 & \\
\hline & & & & $\log \mathrm{P}(<5)$ & 3.03 & \\
\hline Curcuma longa. & 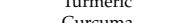 & Curcumin & $\mathrm{C} 21 \mathrm{H} 20 \mathrm{O} 6$ & H-bond donor (5) & 2 & {$[135,136]$} \\
\hline & & & & H-bond acceptor $(<10)$ & 6 & \\
\hline & & & & Violations & 0 & \\
\hline & & & & Molecular weight $(<500 \mathrm{Da})$ & 196.24 & \\
\hline & & & & $\log \mathrm{P}(<5)$ & 1.86 & \\
\hline Zingiber officiale & Ginger & Zingerol & $\mathrm{C} 11 \mathrm{H} 16 \mathrm{O} 3$ & H-bond donor (5) & 2 & {$[36,143,144]$} \\
\hline & & & & H-bond acceptor $(<10)$ & 3 & \\
\hline & & & & Violations & 0 & \\
\hline & & & & Molecular weight $(<500 \mathrm{Da})$ & 294.39 & \\
\hline & & & & $\log \mathrm{P}(<5)$ & 3.13 & \\
\hline Zingiber officiale & Ginger & Gingerol & $\mathrm{C} 17 \mathrm{H} 26 \mathrm{O} 4$ & H-bond donor (5) & 2 & {$[36,144,145]$} \\
\hline & & & & H-bond acceptor $(<10)$ & 4 & \\
\hline & & & & Violations & 0 & \\
\hline & & & & Molecular weight $(<500 \mathrm{Da})$ & 162.27 & \\
\hline & & & & $\log \mathrm{P}(<5)$ & 1.61 & \\
\hline Allium satioum & Garlic & Allicin & C6H10OS2 & H-bond donor (5) & 0 & [36] \\
\hline & & & & H-bond acceptor $(<10)$ & 1 & \\
\hline & & & & Violations & 0 & \\
\hline & & & & Molecular weight $(<500 \mathrm{Da})$ & 442.37 & \\
\hline & & & & $\operatorname{LogP}(<5)$ & 1.23 & \\
\hline Camellia sinesis & Green tea & Epicatechin gallate & C22H18O10 & H-bond donor (5) & 7 & [139] \\
\hline & & & & H-bond acceptor $(<10)$ & 10 & \\
\hline & & & & Violations & 1 & \\
\hline
\end{tabular}


Table 3. The mode of action against viruses and methods of active compound extraction from medicinal plants.

\begin{tabular}{|c|c|c|c|c|c|c|c|c|c|}
\hline \multirow[b]{2}{*}{$\begin{array}{l}\text { Plant Species and } \\
\text { Plant Part }\end{array}$} & \multicolumn{4}{|c|}{ Active Compounds } & \multirow[b]{2}{*}{ Coumarins } & \multirow[b]{2}{*}{ Extract } & \multirow[b]{2}{*}{ Model Organism } & \multirow[b]{2}{*}{$\begin{array}{c}\text { Mode of } \\
\text { Action/Activity }\end{array}$} & \multirow[b]{2}{*}{ Ref } \\
\hline & $\begin{array}{l}\text { Terpenes } \\
\text { Terpenoids }\end{array}$ & $\begin{array}{l}\text { Flavonoids } \\
\text { Flavones }\end{array}$ & Alkaloids & Stilbenes & & & & & \\
\hline $\begin{array}{l}\text { Méntha piperíta } \\
\text { (whole plant) } \\
\text { Lamiaceae }\end{array}$ & $\begin{array}{c}\alpha \text {-pinene } \\
\beta \text {-pinene } \\
\beta \text {-caryophyllene } \\
\text { L-Limonene } \\
\text { Menthol }\end{array}$ & $\begin{array}{c}\text { Eriocitrin } \\
\text { Hesperidin } \\
\text { Kaempferol } \\
\text { 7-O-rutinoside } \\
\text { Luteolin and its } \\
\text { derivatives }\end{array}$ & $\mathrm{n} / \mathrm{a}$ & Trans-resveratrol & $\mathrm{n} / \mathrm{a}$ & Ethanol & Vero cell cultures & $\begin{array}{l}\text { High antiviral } \\
\text { activity }\end{array}$ & [145-147] \\
\hline $\begin{array}{l}\text { Thymus vulgaris } \\
\text { (whole plant) } \\
\text { Lamiaceae }\end{array}$ & $\begin{array}{c}\text { Thymol } \\
\text { p-cymene } \\
\text { g-erpinene } \\
\gamma \text {-Terpinene } \\
\text { Linalool }\end{array}$ & $\begin{array}{c}\text { Rutin } \\
\text { Quercetin }\end{array}$ & $\mathrm{n} / \mathrm{a}$ & $\mathrm{n} / \mathrm{a}$ & $\mathrm{n} / \mathrm{a}$ & Ethanol & Vero cell cultures & $\begin{array}{l}\text { High antiviral } \\
\text { activity and } \\
\text { antioxidant effects }\end{array}$ & {$[145,148,149]$} \\
\hline $\begin{array}{c}\text { Desmodium } \\
\text { canadense } \\
\text { (whole plant) } \\
\text { Fabaceae }\end{array}$ & $\begin{array}{c}\text { Sandosaponin B } \\
\text { and its deriva- } \\
\text { tivesSoyasaponin } \\
\text { I Soyasaponin VI }\end{array}$ & $\begin{array}{l}\text { Homoorientin } \\
\text { Orientin } \\
\text { 2-vicenin } \\
\text { Vitexin } \\
\text { Isovitexin } \\
\text { Rutin } \\
\text { Desmodin } \\
\text { Homoadonivernite }\end{array}$ & $\begin{array}{l}\text { Indole-3- } \\
\text { alkylamine } \\
\text { phenylethylamine } \\
\text { alkaloids, } \\
\text { pyrrolidine } \\
\text { alkaloids }\end{array}$ & $\mathrm{n} / \mathrm{a}$ & $\mathrm{n} / \mathrm{a}$ & Ethanol & Vero cell cultures & $\begin{array}{l}\text { High antiviral } \\
\text { activity }\end{array}$ & {$[145,150-153]$} \\
\hline $\begin{array}{c}\text { Camellia japonica } \\
\text { (whole plant, } \\
\text { flowers) } \\
\text { Theaceae }\end{array}$ & $\begin{array}{c}\text { Oleanane } \\
\text { triterpenes } \\
3 \beta, 18 \beta- \\
\text { dihydroxy-28- } \\
\text { norolean-12-en- } \\
16-\text {-one } \\
\text { 18 } \beta \text {-hydroxy-28- } \\
\text { norolean-12-ene- } \\
\text { 3,16-dione }\end{array}$ & $\begin{array}{l}\text { Quercetin } \\
\text { Kaempferol } \\
\text { Apigenin }\end{array}$ & $\begin{array}{l}\text { Do not produce } \\
\text { purine alkaloids }\end{array}$ & $\mathrm{n} / \mathrm{a}$ & 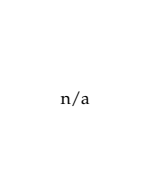 & Ethanol & $\begin{array}{l}\text { Vero cells (African } \\
\text { green monkey } \\
\text { kidney cell line; } \\
\text { ATCC CCR-81) }\end{array}$ & $\begin{array}{l}\text { High antiviral } \\
\text { activity on PEDV } \\
\text { corona virus } \\
\text { Inhibitory effects on } \\
\text { key gene and protein } \\
\text { synthesis during } \\
\text { PEDV replication }\end{array}$ & [154-159] \\
\hline $\begin{array}{c}\text { Saposhnikovia } \\
\text { divaricate } \\
\text { (whole plant) } \\
\text { Apiaceae }\end{array}$ & Sriv nivic & $\mathrm{n} / \mathrm{a}$ & $\mathrm{n} / \mathrm{a}$ & $\mathrm{n} / \mathrm{a}$ & $\begin{array}{c}\text { cis- }{ }^{\prime} \text { - } \\
\text { Isovaleryl4 } \\
\text { acetylkhellactone } \\
\text { Praeruptorin F } \\
\text { Praeruptorin B } \\
\text { (-)-cis- } \\
\text { khellactone }\end{array}$ & Ethanol & $\begin{array}{l}\text { Vero cells (African } \\
\text { green monkey } \\
\text { kidney cell line; } \\
\text { ATCC CCR-81) }\end{array}$ & $\begin{array}{l}\text { High antiviral } \\
\text { activity on PEDV } \\
\text { corona virus }\end{array}$ & [155] \\
\hline $\begin{array}{l}\text { Quercus ilex L. } \\
\text { (Leaves) } \\
\text { Fagaceae }\end{array}$ & & $\begin{array}{c}\text { kaempferol } \\
\text { glycosides } \\
\text { (juglanin, } \\
\text { kaempferol-3-O- } \alpha \text { - } \\
\text { L- } \\
\text { arabinofuranoside, } \\
\text { and afzelin, } \\
\text { kaempferol-3-O- } \alpha \text { - } \\
\text { L-rhamnoside }\end{array}$ & $\mathrm{n} / \mathrm{a}$ & $\mathrm{n} / \mathrm{a}$ & $n / a$ & DMSO & Xenopus oocytes & $\begin{array}{l}\text { Inhibits 3a channel } \\
\text { protein of } \\
\text { coronavirus }\end{array}$ & {$[156,157]$} \\
\hline $\begin{array}{l}\text { Bupleurum sp. } \\
\text { (whole plant) } \\
\text { Apiaceae }\end{array}$ & $\begin{array}{c}\text { Triterpenoid } \\
\text { saponins } \\
\text { Saikosaponins } \\
2^{\prime \prime}-O- \\
\text { Acetylsaikosaponins } \\
\text { Prosaikogenins } \\
\text { Bupleurosides } \\
\text { Etc. }\end{array}$ & $\begin{array}{l}\text { Quercetin } \\
\text { Isorhamnetin } \\
\text { Narcissin } \\
\text { Rutin } \\
\text { Eugenin } \\
\text { Saikochrome A }\end{array}$ & $\mathrm{n} / \mathrm{a}$ & $\mathrm{n} / \mathrm{a}$ & $\mathrm{n} / \mathrm{a}$ & DMSO & $\begin{array}{l}\text { Human fetal lung } \\
\text { fibroblasts } \\
\text { (MRC-5; ATCC } \\
\text { CCL-171) }\end{array}$ & $\begin{array}{l}\text { Saikosaponins } \\
\text { attenuate viral } \\
\text { attachment and } \\
\text { penetration }\end{array}$ & {$[160,161]$} \\
\hline $\begin{array}{l}\text { Houttuynia cordata } \\
\text { (whole plant) } \\
\text { (Saururaceae) }\end{array}$ & $\begin{array}{l}\text { Cycloart-25-ene- } \\
\text { 3b,24-diol }\end{array}$ & $\begin{array}{l}\text { Quercetin } \\
\text { 7-rhamnoside } \\
\text { Hyperin } \\
\text { Quercetin } \\
\text { Afzelin } \\
\text { Rutin }\end{array}$ & $\begin{array}{l}\text { Arisolactams } \\
\text { Piperolactam A } \\
\text { Caldensin }\end{array}$ & 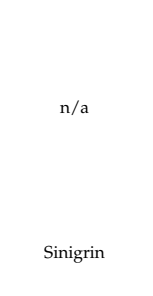 & $\mathrm{n} / \mathrm{a}$ & Water & $\mathrm{BALB} / \mathrm{c}$ mice & $\begin{array}{l}\text { Decreases the viral } \\
\text { SARS-3CLPro } \\
\text { activity } \\
\text { Stops viral t RNA } \\
\text { polymerase activity } \\
\text { (RdRp) } \\
\text { Increases the } \\
\text { secretion of } \\
\text { interleukin (IL)-2 and } \\
\text { (II)-10 } \\
\text { Cleavage of the } \\
\text { activity of } \\
\text { SARS-3CLPro } \\
\text { enzyme decreased }\end{array}$ & {$[163,164]$} \\
\hline $\begin{array}{l}\text { Lycoris radiata } \\
\text { (Bulbs) } \\
\text { Amaryllidaceae }\end{array}$ & $\begin{array}{l}\beta \text {-Myrcene } \\
\text { A-terpineol } \\
\text { Eucalyptol } \\
\beta \text {-cyclocitral }\end{array}$ & $\mathrm{n} / \mathrm{a}$ & $\begin{array}{l}\text { Lycorine } \\
\text { Amaryllidaceae } \\
\text { alkaloids } \\
\text { Lycoranines }\end{array}$ & $\mathrm{n} / \mathrm{a}$ & & Ethanol & Vero E6 cells & $\begin{array}{l}\text { Exhibits } \\
\text { anti-SARS-CoV } \\
\text { activity }\end{array}$ & {$[16,165-167]$} \\
\hline $\begin{array}{l}\text { Litchi chinensis } \\
\text { (seeds) } \\
\text { Sapindaceae }\end{array}$ & $\begin{array}{l}\text { 3-Oxotrirucalla- } \\
\text { 7,24-dien-21-oic } \\
\text { acid }\end{array}$ & $\begin{array}{c}\text { Herbacetin } \\
\text { Rhoifolin } \\
\text { Pectolinarin } \\
\text { Quercetin } \\
\text { Epigallocatechin } \\
\text { gallate } \\
\text { Gallocatechin } \\
\text { gallate } \\
\text { Litchitannins } \\
\text { Kaemferol } \\
\text { derivatives } \\
\text { Epicatechin } \\
\text { Cinnamtannin }\end{array}$ & $\mathrm{n} / \mathrm{a}$ & $\mathrm{n} / \mathrm{a}$ & $\mathrm{n} / \mathrm{a}$ & Water & $\begin{array}{l}\text { On model with } \\
\text { SARS-CoV } \\
\text { 3CLPro }\end{array}$ & $\begin{array}{l}\text { Inhibits } \\
\text { SARS-3CLPro } \\
\text { activity }\end{array}$ & [168-171] \\
\hline $\begin{array}{l}\text { Stephania tetrandra } \\
\text { S Moore } \\
\text { (Roots) } \\
\text { Menispermaceae }\end{array}$ & $\mathrm{n} / \mathrm{a}$ & - & $\begin{array}{l}\text { Tetrandrine } \\
\text { Fangchinoline, } \\
\text { Cepharanthine }\end{array}$ & $\mathrm{n} / \mathrm{a}$ & $\mathrm{n} / \mathrm{a}$ & DMSO & $\begin{array}{l}\text { Human cell line } \\
\text { MRC- }-5 \text { cells }\end{array}$ & $\begin{array}{c}\text { Inhibits the } \\
\text { expression of } \\
\text { HCoV-OC } 43 \text { spike } \\
\text { and nucleocapsid } \\
\text { protein. } \\
\text { Immunomodulation/ }\end{array}$ & {$[129,172]$} \\
\hline $\begin{array}{l}\text { Scutellaria } \\
\text { baicalensis } \\
\text { (Roots) } \\
\text { Lamiaceae }\end{array}$ & Dodecanedioxins & $\begin{array}{l}\text { Scutellarein } \\
\text { Baicalin } \\
\text { Wogonin } \\
\text { Wogonoside }\end{array}$ & $\mathrm{n} / \mathrm{a}$ & $\mathrm{n} / \mathrm{a}$ & $\mathrm{n} / \mathrm{a}$ & DMSO & $\begin{array}{c}\text { Model with } \\
\text { SARS-CoV } \\
\text { helicase, and } \\
\text { nsP13 }\end{array}$ & $\begin{array}{l}\text { Innibits nsP13 by } \\
\text { affecting the ATPase } \\
\text { activity }\end{array}$ & {$[61,173]$} \\
\hline $\begin{array}{l}\text { Allium sativum } \\
\text { (Bulbs) } \\
\text { Alliaceae }\end{array}$ & $\begin{array}{c}\text { Nerolidol Phytol } \\
\text { Squalene } \\
\alpha \text {-pinene } \\
\text { Terpinolene } \\
\text { Limonene } \\
\text { 1,8-cineole } \\
\gamma \text {-terpinene }\end{array}$ & $\begin{array}{l}\text { Catechin } \\
\text { Epicatechin }\end{array}$ & $\begin{array}{c}\text { Allicin } \\
\text { Ajoene } \\
\text { Alliin } \\
\text { Diallyl disulfide } \\
\text { Diallyl trisulfide }\end{array}$ & $\mathrm{n} / \mathrm{a}$ & $\mathrm{n} / \mathrm{a}$ & Aquaporin & Chicken embryos & $\begin{array}{l}\text { Inhibitory effects on } \\
\text { avian coronavirus }\end{array}$ & [174-177] \\
\hline
\end{tabular}


Table 3. Cont.

\begin{tabular}{|c|c|c|c|c|c|c|c|c|c|}
\hline \multirow[b]{2}{*}{$\begin{array}{l}\text { Plant Species and } \\
\text { Plant Part }\end{array}$} & \multicolumn{4}{|c|}{ Active Compounds } & \multirow[b]{2}{*}{ Coumarins } & \multirow[b]{2}{*}{ Extract } & \multirow[b]{2}{*}{ Model Organism } & \multirow[b]{2}{*}{$\begin{array}{c}\text { Mode of } \\
\text { Action/Activity }\end{array}$} & \multirow[b]{2}{*}{ Ref } \\
\hline & $\begin{array}{c}\text { Terpenes } \\
\text { Terpenoids }\end{array}$ & $\begin{array}{l}\text { Flavonoids } \\
\text { Flavones }\end{array}$ & Alkaloids & Stilbenes & & & & & \\
\hline $\begin{array}{l}\text { Artemisia sp. } \\
\text { Artemisia } \\
\text { absentium } \\
\text { (whole plants) } \\
\text { Asteraceae }\end{array}$ & $\begin{array}{l}\text { Absinthin } \\
\text { Artemisin } \\
\text { Scopoletin } \\
\text { Artamarin }\end{array}$ & $\begin{array}{c}\text { Rutin } \\
\text { Glycosides of } \\
\text { quercetin }\end{array}$ & $\begin{array}{l}\text { Artamarin } \\
\text { Artamaridin, } \\
\text { Artamaridinin, } \\
\text { Artamarinin } \\
\text { Quebrachito- } \\
\text { 1Artemitin }\end{array}$ & $\mathrm{n} / \mathrm{a}$ & $\mathrm{n} / \mathrm{a}$ & Water & $\begin{array}{l}\text { Delayed brain } \\
\text { tumor cells }\end{array}$ & $\begin{array}{l}\text { Reduces coronavirus } \\
\text { replication }\end{array}$ & {$[178,179]$} \\
\hline $\begin{array}{c}\text { Juniperus } \\
\text { communis } \\
\text { (Fruits) } \\
\text { Cupressaceae }\end{array}$ & $\begin{array}{c}\text { Sugiol } \\
\alpha \text {-pinene } \\
\beta \text {-pinene }\end{array}$ & $\begin{array}{l}\text { Rutin } \\
\text { Scutellarein } \\
\text { Quercetin-3-o- } \\
\text { rhamnoside } \\
\text { quercitrin }\end{array}$ & $\mathrm{n} / \mathrm{a}$ & $\mathrm{n} / \mathrm{a}$ & Umbelliferone & $\mathrm{n} / \mathrm{a}$ & $\begin{array}{c}\text { Protein-molecular } \\
\text { docking with } \\
\text { network } \\
\text { pharmacology } \\
\text { analysis }\end{array}$ & $\begin{array}{l}\text { Inhibits the } \\
\text { replication, 3CLpro }\end{array}$ & {$[180,181]$} \\
\hline $\begin{array}{c}\text { Ecklonia cava } \\
\text { (whole plant) } \\
\text { Lessoniaceae }\end{array}$ & $\mathrm{n} / \mathrm{a}$ & Quercetin & $\mathrm{n} / \mathrm{a}$ & $\mathrm{n} / \mathrm{a}$ & $\mathrm{n} / \mathrm{a}$ & $\mathrm{n} / \mathrm{a}$ & $\begin{array}{l}\text { protein-molecular } \\
\text { docking with } \\
\text { network } \\
\text { pharmacology } \\
\text { analysis }\end{array}$ & $\mathrm{PL}^{\text {pro }}$ and $3 \mathrm{CL}^{\text {pro }}$ & [182] \\
\hline
\end{tabular}

\subsection{Lectins}

Lectins are a special type of natural proteins (split into seven different classes of evolutionarily- and structurally-related proteins) found in higher plants that bind to the sugar moieties of a wide range of glycoproteins [180]. Plant lectins can inhibit virus replication by preventing the adsorption and fusion of HIV in lymphocyte cell cultures [181-189]. Furthermore, the antiviral effect of agglutinins specific for N-acetylglucosamine and mannose on HIV has been reported. The inhibitory effect of these plant lectins has been shown in vitro on infection with influenza A virus, respiratory syncytial virus, and cytomegalovirus [188-190]. The SARS-CoV spike protein contains 23 putative Nglycosylation sites and is heavily glycosylated. Among the putative N-glycosylation sites, 12 have been defined to be glycosylated [191]. It can be expected that the infectivity of the coronavirus will be suppressed by those lectins that are specific to the glycans present in the spike glycoprotein. The antiviral effect of mannose-specific plant lectins has been reported against coronavirus.

\subsection{Quercetin}

Quercetin is a plant-derived flavonol (pigment) that is commonly found in vegetables and fruits. It is known to possess an antioxidant, antiviral, anti-inflammatory, and anticarcinogenic effects, which may reduce risk of infection and improve physical or mental performance. Moreover, quercetin facilitates the ability to stimulate mitochondrial biogenesis and inhibit capillary permeability, platelet aggregation, and lipid peroxidation [20]. Quercetin is widely found in leaves, flowers, barks, nuts, and seeds of a variety of plants such as tomatoes, tea, shallots, grapes, capers, Brassica vegetables, berries, apples, Sambucus canadensis, Hypericum perforatum, and Ginkgo biloba [192]. The recommended consumption of this plant-derived flavonol has been stated to be not less than $4.37 \mathrm{mg} /$ day. Though the highest concentration of quercetin is reported in capers ( $234 \mathrm{mg}$ of flavonol per 100 $\mathrm{g}$ of edible portion), the main plant source for quercetin glycosides is apples, with $7.4 \%$ $13 \mathrm{mg} / 100 \mathrm{~g}$ fruit. During the digestion of food, quercetin and its conjugated metabolites can be converted into a range of metabolites (phenolic acids) by enteric enzymes and bacteria in intestinal mucosal epithelial cells (IMECs) [191]. Quercetin also inhibits the senescence-associated pro-inflammatory response and suppresses stress-induced senescent cells [193]. Numerous in vitro investigations have confirmed the inhibitory impact of quercetin on interleukin 8 (IL-8) and tumor-necrosis factor (TNF- $\alpha$ ) production in cells. Additionally, several studies have shown the protective function of this flavonol against inflammation in human umbilical vein endothelial cells (HUVECs), as well as mediation via the downregulation of vascular cell adhesion molecule 1 (VCAM-1) and CD80 expression $[20,193]$. Quercetin considerably induces the production of derived interferon (IFN) and T helper type 1 (Th-1), and it consequently downregulates Th-2-derived interleukin 4 (IL-4) by normal peripheral blood mononuclear cells. Quercetin has been found to suppress the infection caused by a wide spectrum of influenza strains including A/Puerto Rico/8/34 (H1N1), A/FM-1/47/1 (H1N1), and A/Aichi/2/68 (H3N2) with half-maximal inhibitory 
concentrations ( $\mathrm{IC}_{50}$ ) of $7.76,6.22$, and $2.74 \mu \mathrm{g} / \mathrm{mL}$, respectively $[20,194,195]$. Investigations into influenza mechanisms have shown the positive interactions between the viral HA2 subunit (a mark for antiviral vaccines) and quercetin. This discovery may determine the antiviral potential of quercetin in the early stages of influenza. Furthermore, this anti-viral compound could prevent H5N1 virus entry into the cell [20,194,196].

\subsection{Sulforaphane}

Sulforaphane is an isothiocyanate (isothiocyanate sulforaphane (SFN)) that has been stated to be an antiviral agent. It has been reported that the osteoblast supporting transcription factor Runx2 is essential for the long-term perseverance of antiviral $\mathrm{CD}^{8+}$ memory $\mathrm{T}$ cells [197,198]. An addition, SFN-rich broccoli homogenate attenuated granzyme B production in NK cells that was induced by influenza virus and granzyme B production in NK cells, and granzyme B levels appeared to have negatively interacted with influenza RNA levels in nasal lavage fluid cells [199]. Nasal influenza infection can induce complex cascades of changes in peripheral blood NK cell activation. SFN increases as a result of virus-induced peripheral blood NK cell granzyme B production, which may enhance antiviral defense mechanisms [20,199].

\subsection{Resveratrol}

Resveratrol is a natural polyphenol found in grapes, mulberry, and peanuts. It is known to have antiviral properties against a variety of viral pathogens in vitro and in vivo [200]. Resveratrol is available in trans- and cis-isomeric forms. The cis-resveratrol isomer is unstable and can be easily transformed into the trans form when it reacts with light. It was demonstrated that resveratrol substantially inhibited MERS-CoV replication in vitro through the inhibition of RNA production, as well as other pleiotropic effects. Studies have shown that indomethacin and resveratrol can act as adjuncts for SARSCoV-2/COVID-19 [201,202]. Medina-Bolivar et al. developed the hairy root lines from Arachis hypogaea (peanut) for the sustained and reproducible production of resveratrol and resveratrol derivatives [201].

\subsection{Baicalin}

Baicalin (baicalein glucuronide) accumulates in the roots of Scutellaria baicalensis [202]. Baicalin has been reported as an antioxidant possessing anti-apoptotic properties, and it has been used for pulmonary arterial hypertension treatment [203]. This flavone glucuronide has been reported to have anti-SARS-CoV inhibitory effects comparable to those of interferon-beta 1a, interferon-alpha, and glycyrrhizin. At the same time, this compound has a low toxicity in human cell lines [204]. Baicalin showed considerable anti-viral properties on lipopolysaccharide-activated cells, while the oral application of baicalin expressively increased the survival rate of influenza A virus-infected mice [57]. The in silico analysis of the inhibitory effect of baicalin showed that this flavone inhibits ACE2 in the case of COVID-19 disease. It has been revealed that baicalin can inhibit 3CL Pro activity of the SARS-Cov2 virus in vitro [205].

\subsection{Glycyrrhizin}

Glycyrrhizin (a triterpene saponin) is one of the most important phytochemical components of the Glycyrrhiza glabra (licorice) root [206]. Glycyrrhizin has anti-inflammatory and antioxidant properties used for treatments of different diseases such as jaundice, bronchitis, and gastritis [204]. Glycyrrhizin could block the SARS-Cov virus attachment to the host cells, especially during the initial stage of the viral life cycle [207]. An in silico analysis of glycyrrhizin behavior showed the inhibitory effect of this compound on SARS-Cov2 [208].

\subsection{Narcissoside}

Narcissoside (synonym: narcissin) is a phytochemical belonging to the group of mono-methoxyflavones. This isorhamnetin-3-O-rutinoside flavonoid is extracted from 
leaves of various folk plants such as Atriplex halimus L., Gynura divaricate, Caragana spinose, and Manihot escylenta. An in silico analysis demonstrated that narcissoside has inhibitory potential for the viral COVID 19 protein 6W63 [209].

\subsection{Curcumin}

Curcumin is diarylheptanoid that possesses inflammatory and antioxidant properties and is mainly extracted from Alpinia galanga, Curcuma longa, and Caesalpinia sappan [210]. This active compound has been applied in the treatment of hyperlipidemia, anxiety, arthritis, and metabolic syndrome [211]. Additionally, curcumin displays antibacterial and antiviral properties against Pseudomonas, Streptococcus, and Staphylococcus strains, as well as HIV, hepatitis $C$, and the influenza virus. Moreover, antiviral properties of this compound have been reported against chikungunya virus (CHIKV), human papillomavirus (HPV), HIV-1 and HIV-2 proteases, emerging arboviruses like the Zika virus (ZIKV), influenza viruses, HIV, HSV-2, and hepatitis viruses [212]. However, due to its rapid elimination, rapid metabolism, and poor absorption, curcumin has poor bioavailability, which reduces its therapeutic effect [213]. It has been reported that the combination of this diarylheptanoid with other chemical compounds like piperine can increase bioavailability (by up to $2000 \%$ ) and provide multiple benefits to human health [214,215]. This compound can diminish various forms of free radicals, such as reactive nitrogen and oxygen species, and modulate the function of SOD [216], catalase, and GSH enzymes in the neutralization of free radicals [217]. Furthermore, curcumin can block ROS-generating enzyme activities such as xanthine oxidase/hydrogenase and cyclooxygenase/lipoxygenase [20]. It has been reported that this plant-derived compound can inhibit the NF- $\mathrm{kB}$ activation caused by numerous inflammatory stimuli such as markers of soluble vascular cell adhesion molecule 1 (sVCAM-1), IL-1 beta, IL-6, and inflammation (soluble CD40 ligand (sCD40L)). The results of studies have shown that curcumin can inhibit SARS-CoV through binding to three different protein receptors: SARS-CoV-2 protease (PDB ID:6LU7), PD-ACE2 (PDB ID: 6VW1), and RBD-S (PDB ID:6LXT) [218].

\subsection{Epigallocatechin Gallate}

Epigallocatechin gallate or epigallocatechin-3-gallate is the ester of gallic acid and epigallocatechin [219]. This compound possesses activity against neurological diseases, premature aging, metabolic diseases, and inflammation [220]. Epigallocatechin gallate has shown anti-inflammatory and antioxidative properties, facilitated DNA repair and stability, ensured the modifications of miRNAs, and modulated the epigenetic methylation of histones $[20,221]$. The antiviral activity of this compound has been reported against a broad spectrum of viruses such as hepatitis B virus (HBV; Hepadnaviridae), human papillomavirus (HPV; Papovaviridae), adenovirus (Adenoviridae), and herpes simplex virus (HSV; Herpesviridae). It has been observed that epigallocatechin gallate can inhibit (+)-RNA viruses such as chikungunya virus (CHIKV; Togaviridae), West Nile viruses (WNV; Flaviviridae), dengue virus (DENV; Flaviviridae), Zika virus (ZIKV; Flaviviridae), and hepatitis $\mathrm{C}$ virus (HCV; Flaviviridae). On the other hand, it can inhibit (-)-RNA viruses such as influenza virus (Orthomyxoviridae), Ebola virus (EBOV; Filoviridae), and HIV (Retroviridae) [13]. Epigallocatechin gallate inhibits the early stage of infections, such as attachment, entry, and membrane fusion, by interfering with viral membrane proteins [222]. The anti-viral mechanism of this compound may be generated from interactions with helicase, ACE-2, and DNMTs [20].

\section{Laboratory Evidence Supporting Application of Medicinal Plants Against Respiratory Disorders}

Some investigations have identified the antiviral properties of medicinal plants against bronchitis. For example, it has been demonstrated that Verbascum thapsus, Justicia adhatoda, and Hyoscyamus niger can reduce infections risks associated with influenza viruses [108]. Polyphenol, extracted from Cistus incanus (a Mediterranean plant), possesses anti-influenza activity in MDCK and A549 cell cultures infected with human influenza strains and differ- 
ent subtypes of the avian virus [223]. Similarly, sambucol, extracted from Sambucus nigra, showed positive activity against influenza by boosting immune responses through the secretion of inflammatory cytokines (IL-1 beta, TNF-alpha, IL-6, and IL-8) [224].

\subsection{Artemisia annua}

Artemisia annua (commonly known as sweet wormwood) is a traditional Chinese medicinal herb. It is a source of the sesquiterpene lactone artemisinin, which is used for the manufacturing of the antimalarial drugs artemether and artesunate [225]. The results of an investigation demonstrated that artemisinin is a reliable source to act as an antiviral compound [226]. Furthermore, sterols extracted from A. annua presented inhibitory potential against viruses [227]. An in vitro investigation on the antiviral properties of $A$. annua against SARS-CoV showed positive feedback by using an ethanolic extract with a $50 \%$ effective concentration $\left(\mathrm{EC}_{50}\right)$ value of $34.5 \pm 2.6 \mu \mathrm{g} / \mathrm{mL}$ and $5 \mathrm{a} 0 \%$ cytotoxic concentration $\left(\mathrm{CC}_{50}\right)$ of $1053 \pm 92.8 \mu \mathrm{g} / \mathrm{mL}$. This result suggested the possibility of applying A. annua against SARS-CoV infectious diseases [16]. An analysis of antiviral activity of methanolic extracts of $A$. annua against herpes simplex virus type 1 showed the antiviral properties of the aerial parts of plant. It has been suggested that high levels of bioactive compounds are the main reasons for antiviral activities, which has led to the use of this plant as a potential candidate against viruses [226]. Pulmonary fibrosis (lungs become scarred) is caused by the infection of SARS-CoV with spiked severity, which mediated by interleukin-1 [227]. It has been shown that the consumption of natural antioxidants like polyphenolic compounds [228] is effective in the treatment of lung fibrosis associated with oxidative stress [229]. The positive effect of artesunate, an artemisinin-based drug, to treat pulmonary fibrosis was confirmed due to it inhibiting pro-fibrotic molecules linked to pulmonary fibrosis [230].

\subsection{Allium сера}

Allium cepa (commonly known as onion) is a common raw material served in salad and is rich in natural resources of organosulfur and flavonoids with antioxidant activity [231]. Reportedly, quercetin and isorhamnetin (two potential therapeutic agents in onion) can reduce blood pressure and prevent angiotensin-II-induced endothelial dysfunction. Furthermore, superoxide production was increased and subsequently and led to a high nitric oxide bioavailability [232]. It has been reported that the chemical compounds of onion-like flavonoids or even prolines possess antiviral properties against respiratory viruses by stimulating proinflammatory cytokines [233].

\subsection{Andrographis paniculata}

Andrographis paniculata (which is commonly known as King of Bitters) is extensively applied in the treatment of several ailments like liver disorders, viral fever, cold, and cough [231]. Andrographis paniculata has shown a strong therapeutic effect against viral respiratory infections [234-237] by suppressing interleukin-1 $\beta$ molecules and increasing NOD-like receptor protein 3 (NLRP3) and caspase-1, which are widely known to play roles in SARS-CoV and likely SARS-CoV-2 pathogenesis [238,239]. Andrographolide (a diterpenoid), is the main bioactive compound extracted from the leaves and stem of this plant and possesses anti-inflammatory capacity. Notably, andrographolide has antiviral potential against different viruses diseases such as chikungunya virus, human immunodeficiency virus, human papillomavirus, Epstein-Barr virus, herpes simplex virus, hepatitis C and B, and influenza A virus (H1N1, H5N1, and H9N2) [125].

\subsection{Aloe vera}

Aloe vera is a kind of medicinal plant that possesses antiviral activity against different viruses including human papillomavirus, cytomegalovirus, poliovirus, influenza virus, human immunodeficiency virus, varicella-zoster virus, herpes simplex virus type 2 , herpes simplex virus type 1 , and hemorrhagic viral rhabdovirus septicemia. Molecular 
investigations have shown the effectiveness of this plant against other viruses by different action mechanisms such as the breakdown of the viral envelope and interactions with virus enzymes. The presence of some minerals like zinc, copper $(\mathrm{Cu})$, iron $(\mathrm{Fe})$, potassium $(\mathrm{K})$, sodium $(\mathrm{Na})$, magnesium $(\mathrm{Mg})$, and calcium $(\mathrm{Ca})$ make Aloe vera a suitable candidate against SARS-CoV-1 [240]. Reports have shown that $\mathrm{Zn}^{2+}$ blocks arterivirus RNA polymerase and SARS-CoV activity and inhibits SARS-CoV replication in cell lines [241] (Figure 3).

\begin{tabular}{|c|c|c|c|c|}
\hline Molecules & & Mode of action & \multicolumn{2}{|c|}{$\begin{array}{c}\text { Genome type of Types of viruses } \\
\text { virus }\end{array}$} \\
\hline Aloin & $\Longrightarrow$ & $\begin{array}{l}\text { Destruction of the phospholipid } \\
\text { double layer by incorporation into } \\
\text { the viral envelope }\end{array}$ & RNA & $\begin{array}{l}\text { Haemorrhagic Viral } \\
\text { Rhobdavirus } \\
\text { Septicaemia (VHS) }\end{array}$ \\
\hline & & $\begin{array}{l}\text { Aloe-emodin inhibits the eleavage of } \\
3 \text { C-like protense, an encyme that } \\
\text { plays an important role in viral } \\
\text { replication by acting on the } \\
\text { proteolytic process at the replicase } \\
\text { level }\end{array}$ & RNA & SARS coronovirus (SARSCoV1) \\
\hline Aloe-emodin & 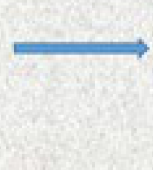 & $\begin{array}{l}\text { Inhibition of nucleic acid biosynthesis } \\
\text { resulting in the termination of } \\
\text { protein synthesis }\end{array}$ & DNA & $\begin{array}{l}\text { Herpes simplex virus type } 1 \\
\text { (HSV-1) } \\
\text { DNA } \\
\text { HSV-2 } \\
\text { Varicella-Zoster virus (VZV) }\end{array}$ \\
\hline Acemannan & $\Rightarrow$ & $\begin{array}{l}\text { Acemannan inhibits glycosylation of } \\
\text { viral proteins and inhibits cell fusion } \\
\text { and suppression of virus release }\end{array}$ & RNA & HIV-1 \\
\hline Chrysophanic acid & $\Longrightarrow$ & $\begin{array}{l}\text { This molecule prevents the } \\
\text { penetration of the virus into the cell, } \\
\text { either the translation of the viral } \\
\text { RNA or the initial cleavage of the } \\
\text { viral protein }\end{array}$ & $\Rightarrow$ & Poliovirus \\
\hline Lectins & $\Longrightarrow$ & $\begin{array}{l}\text { Leptins inhibit CMV proliferation by } \\
\text { interfering with protein synthesis }\end{array}$ & DNA & $\begin{array}{l}\text { Cytomegalovirus (CMV) } \\
\text { Human papillomavirus } \\
\text { (HRHPV) }\end{array}$ \\
\hline
\end{tabular}

Figure 3. Antioxidant properties of Aloe vera.

\subsection{Nigella sativa}

Nigella sativa (black seed) is a kind of medicinal plant used for the treatment of a variety of diseases, disorders, and conditions pertaining to the respiratory system, immune systems and cardiovascular, liver, kidneys, and digestive tract. Recently, the result of studies showed that the oil extract of N. sativa reduced the H9N2 avian influenza virus (which is fundamentally associated to SARS-CoV-2 pathogenicity in chicken), and consequently supported the immune response. The most important active compounds which have been identified in N. sativa are monoterpenes, e.g., t-anethol, 4-terpineol, carvacrol, p-cymene, thymohydroquinone, and thymoquinone or dimers thereof like dithymoquinone [20].

\subsection{Salvia officinalis}

Salvia officinalis (sage) is a medicinal plant with antiviral, antibacterial, antimalarial and antifungal effects. Reportedly, the antiviral and antifungal properties of this plant are most probably facilitated by sageone, safficinolide, and diterpenoids [242]. 


\subsection{Toona sinensis}

The crude oil of the tender leaves of Toona sinensis Roem induced apoptosis in A549 lung cancer cells but also improved the lipolysis of differentiated 3T3-L1 adipocytes [243,244]. Further, the leaf extract of $T$. sinensis Roem was reported to relieve hyperglycemia via modifying adipose glucose transporter 4 [245]. Studies of purified compounds of T. sinensis leaves have shown several compounds include toosendanin, phytol, stigmasterol glucoside, beta-sitosterol-glucoside, stigmasterol, beta-sitosterol, (-)-epicatechin, (+)-catechin, kaempferol-D-glucoside, rutin, quercitrin, quercetin, kaempferol, gallic acid, and methyl gallate [246]. Additionally, it has been reported that, quercetin, one of T. sinensis leaves' compounds, has an antiviral impact against HIV-luc/SARS pseudotyped virus [65].

\subsection{Eckolina cava}

Eckolina cava (Laminariaceae) is a type of brown alga with anti-viral activity against influenza virus neuraminidase and HIV-1 reverse transcriptase 11 phlorotannin chemotype (a diphenyl ether-linked dieckol) extracted from E. cava $\left(\mathrm{IC}_{50 \mathrm{~s}}=2.7\right.$ and $\left.68.1 \mu \mathrm{M}\right)$ that was found to highly block the cleavage of SARS-CoV $3 C^{\text {pro }}$ in a cell-based test with no toxicity [182].

\subsection{Isatis indigotica}

Isatis indigotica (I. indigotica root Radix isatidis) is a Chinese medicinal plant belonging to the family of Cruciferae, with a high phenolic content in the root. The root of this plant was frequently applied during the outbreak of SARS in Taiwan, Hong Kong, and China. Additionally, the antiviral effects of different compounds of this plant such as sinigrin, $\gamma$-sitosterol, indican (indoxyl- $\beta$-D-glucoside), $\beta$-sitosterol, indirubin, and indigo have been reported against Japanese encephalitis, hepatitis A, and influenza [247,248]. Indirubin and indigo were recognized as inhibitors of promiscuous chymotrypsin [249]. Moreover, the antiviral effects of naringenin, quercetin, hesperetin, phenolics, and aloe emodin derived from I. indigotica have been accredited against parainfluenza virus, sindbis virus, herpes simplex virus types 1 and 2, vesicular stomatitis virus, poliovirus, and vaccinia virus [250,251]. It has been well-demonstrated that the 3C-like protease (3CL ${ }^{\text {pro }}$ ) can mediate the proteolytic processing of polypeptides $1 \mathrm{a}$ and $1 \mathrm{ab}$ into functional proteins, which is an ideal target for the development of drugs against SARS-coronavirus. In a cell-based assay, the investigation of seven different phenolic compounds derived from I. indigotica revealed that only two polyphenols, namely hesperetin $(8.3 \mu \mathrm{M})$ and emodin $(366 \mu \mathrm{M})$, could inhibit the cleavage activity of the $3 C^{\text {pro }}$ in a dose-dependent manner [163].

\subsection{Azadirachta indica}

Azadirachta indica (commonly known as neem) is a kind of biological antiviral agent against duck plague virus, herpes simplex virus type-1, bovine herpesvirus type- 1 (BoHV1), poliovirus type 1, group B coxsackieviruses, polio, and dengue virus type-2, as well as infectious bursal diseases like viral infections, Newcastle disease, and highly pathogenic avian influenza virus (H5N1) [252]. It has been shown that different extracts of this neem's explants have potential against common clinical symptoms of Covid-19 [253,254]. In this regard, crude leaf extracts of neem could be effective against malarial and normal fever [246], as well as a gastrointestinal disorders [255]. The leaf extract of this plant possesses strong antioxidant potential by directly scavenging the hydroxyl radical and preventing hydroxyl radical-mediated oxidative damage in the rat model [256].

\subsection{Other Medicinal Herbs}

Studies on some medicinal plants including Evolvulus alsinoides, Pergularia daemi, Clerodendrum inerme Gaertn, Clitoria ternatea, Sphaeranthus indicus, Cassia alata, Leucas aspera, Abutilon indicum, Gymnema sylvestre, Vitex trifolia, and Indigofera tinctoria (AO) have shown anti-mouse coronaviral activity [107]. C. inerme Gaertn was observed as a promising medicinal plant having potential to inactivate the viral ribosome [104]. Additionally, 
anti-inflammatory cytokines are significantly reduced by Sphaeranthus indicus and Vitex trifolia when using the nuclear factor kappa-light-chain-enhancer of activated B (NF-kB) signaling cascade, associated with acute respiratory distress syndrome [152] in SARSCoV $[256,257]$. Furthermore, C. ternatea (Asian pigeonwings) has been reported as an inhibitor of metallopeptidase domain 17 (ADAM17), a metalloproteinase involved in angiotensin being converted for enzyme shredding, and can be targeted with Clitoria ternatea. ACE-2 shredding is associated with the spike formation of viruses [105]. Likewise, Strobilanthes cusia was found to inhibit viral RNA genome synthesis and to induce papain like protease ( $\mathrm{PL}^{\mathrm{pro}}$ ) activity targeting the human coronavirus OC43 [1,113]. Allium sativum and Glycyrrhiza glabra have been identified to inhibit the viral replication of SARS-CoV. Inhibitory effects on the $\mathrm{Ca}^{2+}$ channel were observed when Hyoscyamus niger was applied as a bronchodilator [108]. This plant is able to target the orf3a $\mathrm{Ca}^{2+}$ channels that attack downstream pathways upon viral infection. The inhibitory effect of other medicinal plants including Embelia ribes, Cassia occidentalis, Punica granatum, Coscinium fenestratum, Cynara scolymus, Boerhaavia diffusa, and Coriandrum sativum have been identified against ACE [107]. However, Punica granatum has been shown to exhibit a competitive style of action against virus infection [102,103]. Salacia oblonga was found to exhibit suppressive impacts on angiotensin II, an AT1 signal, which was related to lung damage [109] (Table 4).

Table 4. List of commonly used medicinal herbs involved in treatment of respiratory disorders.

\begin{tabular}{|c|c|c|c|}
\hline Scintific Name & Common Names & Mode of Action & References \\
\hline Tinospora cordifolia & Heart-leaved moonseed & Chronic fever & \\
\hline Andrograhis paniculata & Creat or green chireta & Fever and cold & \\
\hline Cydonia oblonga & Quince & Antioxidant, immune-modulatory, anti-allergic, smooth & \\
\hline Zizyphus jujube & Jujube & muscle relaxant, and anti-influenza activity & \\
\hline Agastya haritaki & $\begin{array}{l}\text { Iasura } \\
\text { Agastya Rasayana }\end{array}$ & Upper respiratory infections & \\
\hline Anu Thailam & 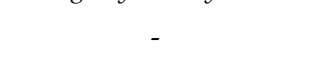 & $\begin{array}{l}\text { Respiratory infections } \\
\text { Fever }\end{array}$ & {$[257,258]$} \\
\hline Adathoda siddha & Malabar nut & Fever & \\
\hline Bryonia alba & White bryony & Reduce lung inflammation & \\
\hline Rhus toxicodendron & Eastern Poison Oak & Viral infections & \\
\hline $\begin{array}{c}\text { Atropa } \\
\text { belladonna }\end{array}$ & Deadly nightshade & Asthma and chronic lung diseases & \\
\hline $\begin{array}{l}\text { Bignonia } \\
\text { sempervirens }\end{array}$ & Yellow jessamine & Asthma & \\
\hline Eupatorium perfoliatum & Agueweed & Respiratory symptoms & \\
\hline Kabasura Kudineer & - & $\begin{array}{c}\text { Fever, cough, sore throat, shortness of } \\
\text { breath }\end{array}$ & \\
\hline Abutilon indicum & Mallow & Immunomodulatory function & {$[107,259]$} \\
\hline Withania somnifera & Ashwagandha & $\begin{array}{l}\text { General tonic and to boost immunity/against herpes } \\
\text { simplex virus }\end{array}$ & [260] \\
\hline Hydrastis canadensis & $\begin{array}{l}\text { Goldenseal } \\
\text { root }\end{array}$ & $\begin{array}{c}\text { Reduces plasma TNF- } \alpha, \text { INF- } \gamma \text {, and } \\
\text { NO levels; inhibits the T helper-type } 2 \\
\text { cytokine profile. }\end{array}$ & [261] \\
\hline Acalypha indica & Indian Acalypha & Anthelmintic & [262] \\
\hline Achyranthes aspera & Prickly chaff flower & Anti-viral activity & [263] \\
\hline Momordica charantia & bitter melon & $\begin{array}{c}\text { Inhibits the release of TNF- } \alpha \text {, } \\
\mathrm{NO} \text { and proliferation of spleen cells } \\
\text { induced by PHA and Con } \mathrm{A} .\end{array}$ & [261] \\
\hline Adhatoda vasica & Adulsa & Anti-asthmatic, anti-allergic and anti-tussive activity & {$[264]$} \\
\hline Nigella sativa & Black cumin & $\begin{array}{c}\text { cell (PDA) synthesis of monocyte } \\
\text { chemoattractant protein-1 (MCP-1), TNF- } \\
\alpha, \text { IL-1 } \beta \text {, and cyclooxygenase (COX)-2, } \\
\text { as well as inhibiting the polymorphonuclear leukocyte } \\
\text { functions. }\end{array}$ & [261] \\
\hline Alangium salvifolium & Sage-leaved alangium & Anti-rheumatoid & [265] \\
\hline Urtica dioica & Common Nettle & $\begin{array}{l}\text { Reduction of TNF- } \alpha \text { and other } \\
\text { inflammatory cytokines }\end{array}$ & {$[261]$} \\
\hline Cassia alata & Candle Bush & Anti-helmintic activity & {$[107,266]$} \\
\hline Cassia fistula & Golden Shower & Antibacterial activity & [267] \\
\hline
\end{tabular}


Table 4. Cont.

\begin{tabular}{|c|c|c|c|}
\hline Scintific Name & Common Names & Mode of Action & References \\
\hline Cayratia pedata & Birdfoot Grape & Anti-inflammatory activity & [268] \\
\hline Chloroxylon swietenia & East Indian satinwood & Anti-helmintic activity & [269] \\
\hline Clitoria ternatea linn. & Asian pigeonwings & Anti-oxidant activity & [270] \\
\hline Eugenia singampattiana & Jungle Guava & Anti-inflammatory activity & {$[107,268]$} \\
\hline Hippophae rhamnoides & Sea-buckthorn & $\begin{array}{c}\text { Eliminating phlegm, stopping coughing, improving } \\
\text { digestion, and treating lung diseases }\end{array}$ & [271] \\
\hline Indigofera tinctoria & True Indigo & Immunomodulatory function & {$[107,272]$} \\
\hline Justicia adhatoda & Malabar Nut & $\begin{array}{l}\text { Anti-oxidant and anti-mutagenic activity; hepatoprotective } \\
\text { activity }\end{array}$ & $\begin{array}{l}{[1,236,273-} \\
275]\end{array}$ \\
\hline Leucas aspera & Thumbai & Hepatoprotective activity, acaricidal properties & {$[107,276,277]$} \\
\hline $\begin{array}{l}\text { Mucuna pruriens } \\
\text { Xanthium strumanium }\end{array}$ & $\begin{array}{l}\text { Monkey Tamarind } \\
\text { Common Cocklebur }\end{array}$ & Antibacterial drugs against pneumonia & [278] \\
\hline Pergularia daemia & Pergularia & Hepatoprotective effect & {$[107,279]$} \\
\hline Piper longum & Long pepper & Anti-pneumonia drug & [280] \\
\hline Salacia reticulata & Meharimula & Anti-inflammatory activity & [268] \\
\hline Santalum album & White Sandalwood & $\begin{array}{c}\text { Anti-inflammation of the lungs, blood, and pus in the } \\
\text { sputum }\end{array}$ & [271] \\
\hline Solanum tornum & Turkey Berry & Anti-pneumonia drug & [281] \\
\hline Solanum suratens & Surattense Nightshade & Anti-viral activity & [263] \\
\hline Solanum xanthocarpum & Yellow-fruit nightshade & Anti-asthmatic & {$[264,271]$} \\
\hline Strychnos minor & Snakewood & Anti-inflammatory activity & [268] \\
\hline Strychnosnux vomica & Strychnine tree & Anti-inflammatory activity & [268] \\
\hline Syzygium aromaticum & Caryophyllus & Hepatoprotective properties & [282] \\
\hline Tinospora cordifolia & Moonseed & Anti-pneumonia drug & [283] \\
\hline Trichopus zeylanicus & Arogyapacha & Anti-oxidant and anti-fatigue activity & [284] \\
\hline Tylophora indica & Indian Ipecac & Anti-asthmatic & [264] \\
\hline Verbascum thapsus & Great mullein & Enhancing peroxidase, phenolics, and antioxidant activity & [1] \\
\hline Vitex altissima & Peacock Chaste Tree & Acts against acute inflammation & [285] \\
\hline Vitex trifolia & Hand-of-Mary & Tracheospasmolytic activity & {$[107,257]$} \\
\hline Wrightia tinctoria & Pala Indigo & Anti-inflammatory activity & [268] \\
\hline Yuthog's Bamboo & Bamboo & $\begin{array}{c}\text { Reduction of pain and anti-inflammation of the lungs and } \\
\text { respiratory tract }\end{array}$ & [271] \\
\hline Zingiber officinale & Canton Ginger & $\begin{array}{l}\text { Modulation of macrophage functions, phagocytic } \\
\text { properties, anti-viral activity, and bronchial infections }\end{array}$ & {$[1,286,287]$} \\
\hline Garcinia Kola & Bitter Kola & Anti-bacterial drug against respiratory pathogens & [288] \\
\hline Cymbopogon citratus & West Indian lemon grass & Anti-viral infections & [289] \\
\hline Camellia sinensis & Tea plant & Anti-infective activity & [290] \\
\hline Achillea mellefolium & Yarrow & Protects upper respiratory tract from viral infections & [291] \\
\hline Apium graveolens & Celery & Anti-bacterial and anti-viral agent & [292] \\
\hline Borassus flabellifer & Palmyra Palm & $\begin{array}{c}\text { Protects from pulmonary infections; anti-bacterial and } \\
\text { anti-viral activity }\end{array}$ & [293] \\
\hline Caesalpinia bonduc & Grey Nicker & Treatment for asthma (anti-bacterial and anti-viral agent) & [294] \\
\hline Calotropis gigantea & Crown flower & Anti-bacterial and anti-viral agent & [293] \\
\hline Crocus sativus & Saffron Crocus & Treatment for asthma and cough & [295] \\
\hline Euphorbia hirta & Asthma-Plant & Anti-bacterial and anti-viral agent & [291] \\
\hline Piper nigrum & Black pepper & Anti-viral agent & [296] \\
\hline Strychnos potatorum & Clearing-Nut Tree & Treatment for bronchitis & [297] \\
\hline Terminalia bellirica Roxb & Beleric Myrobalan & Effective for asthma & [298] \\
\hline Tylophora indica Merrill & Antamul & Treatment for bronchitis and asthma & [299] \\
\hline Tussilago farfara & Coltsfoot & Treatment for cough and asthma & [300] \\
\hline Thymus linearis & Himalayan Wild Thyme & Anti-viral activity & [290] \\
\hline Senecio chrysanthemoides & Senecio & Treatment for lung diseases & [301] \\
\hline Portulaca oleracea & Duckweed & Anti-inflammatory and anti-asthma properties & [294] \\
\hline Papaver somniferum & Opium Poppy & Treatment for respiratory diseases & [293] \\
\hline Morus laevigata Wall. ex Brandis & White Mulberry & Treatment for cough & [302] \\
\hline Ephedra gerardiana Wall. ex Stapf & Gerard's Jointfir & Treatment for cough and asthma & [303] \\
\hline Geranium wallichianum & Sylvia's Surprise & Treatment for cough & [292] \\
\hline Micromeria biflora & Lemon Scented Thyme & Treatment for cough & [295] \\
\hline Picrorhiza kurroa Royle ex. Benth & Kutki & Treatment for asthma and bronchitis & [289] \\
\hline Primula denticulata Sm. & Drumstick Primula & Treatment for cough and bronchitis & [304] \\
\hline
\end{tabular}

\section{In Silico Analysis of Medicinal Plants Role Against SARS-CoV}

The in silico analysis of 18 extracted compounds of 11 Indian herbal plants demonstrated different inhibitory properties against Covid-19. Based on the data achieved through $\log \mathrm{S}$ and $\log \mathrm{P}$, as well as the binding affinity (Table 5), the potential inhibitory effect of plants were in the following order: Nyctanthes arbortristis (harsingar) $>$ Aloe barbadensis 
miller (aloe vera) > Tinospora cordifolia (giloy) > Curcuma longa (turmeric) $>$ Azadirachta indica (neem) $>$ Withania somnifera (ashwagandha) $>$ Allium cepa (red onion) $>$ Ocimum sanctum (tulsi) > Cannabis sativa (cannabis) > Piper nigrum (black pepper). However, the results of this investigation confirmed that harsingar, Aloe vera, and giloy are more reliable natural resources for future investigations [305]. The in silico analysis of compounds with anti-viral, anti-malaria, or other similar activities are presented in Table 5.

Table 5. In silico analysis of phenolic compounds extracted form medicinal plants.

\begin{tabular}{|c|c|c|c|c|}
\hline Plant Parts & Scientific Name & $\begin{array}{l}\text { The Major Phenolic } \\
\text { Compound }\end{array}$ & Formula & $\begin{array}{l}\text { Active Sites/Binding } \\
\text { Residue/H-Bond Length (Å) }\end{array}$ \\
\hline Leaves of harsingar & Nyctanthes arbortristis & $\begin{array}{l}\text { Nictoflorin } \\
\text { Astragalin } \\
\text { Lupeol }\end{array}$ & $\begin{array}{l}\mathrm{C}_{27} \mathrm{H}_{30} \mathrm{O}_{15} \\
\mathrm{C}_{21} \mathrm{H}_{20} \mathrm{O}_{11} \\
\mathrm{C}_{25} \mathrm{H}_{26} \mathrm{O}_{4}\end{array}$ & $\begin{array}{c}\text { N-H-O/GLY-143/2.311 } \\
\text { O-H/PHE-140/2.197 } \\
\text { N-H-O/THR-26/2.027 }\end{array}$ \\
\hline Giloy & Tinospora cordifolia & $\begin{array}{l}\text { Berberine } \\
\text { Sitosterol }\end{array}$ & $\begin{array}{c}\mathrm{C}_{28} \mathrm{H}_{18} \mathrm{NO}_{4} \\
\mathrm{C}_{29} \mathrm{H}_{50} \mathrm{O}\end{array}$ & $\begin{array}{c}\text { N-H-O/GLY-143/2.540 } \\
\text { N-H-O/GLY-143/2.577 } \\
\text { O-H/PHE-166/2.080 }\end{array}$ \\
\hline Aloe vera leaves & Aloe barbadensis & $\begin{array}{l}\text { Aloenin } \\
\text { Aloesin }\end{array}$ & $\begin{array}{l}\mathrm{C}_{19} \mathrm{H}_{22} \mathrm{O}_{10} \\
\mathrm{C}_{19} \mathrm{H}_{22} \mathrm{O}_{9}\end{array}$ & $\begin{array}{c}\mathrm{O}-\mathrm{H} / \mathrm{PHE}-140 / 2.151 \\
\mathrm{~N}-\mathrm{H}-\mathrm{O} / \mathrm{GLY}-143 / 2.016 \\
\mathrm{~N}-\mathrm{H}-\mathrm{O} / \mathrm{GLU}-166 / 2.297\end{array}$ \\
\hline $\begin{array}{l}\text { The dried ground } \\
\text { rhizome of the turmeric }\end{array}$ & Curcuma longa & Curcumin & $\mathrm{C}_{21} \mathrm{H}_{20} \mathrm{O}_{6}$ & N-H-O/GLY-143/2.243 \\
\hline The oil of neem & Azadirachta indica & Nimbin & $\mathrm{C}_{30} \mathrm{H}_{36} \mathrm{O}_{9}$ & N-H-O/GLY-143/2.161 \\
\hline $\begin{array}{l}\text { Steroidal constituents } \\
\text { of ashwagandha }\end{array}$ & & $\begin{array}{l}\text { Withanolide } \\
\text { Withaferin A }\end{array}$ & $\begin{array}{l}\mathrm{C}_{28} \mathrm{H}_{38} \mathrm{O}_{6} \\
\mathrm{C}_{28} \mathrm{H}_{38} \mathrm{O}_{6}\end{array}$ & $\begin{array}{c}\mathrm{O}-\mathrm{H} / \mathrm{GLU}-166 / 1.991 \\
\mathrm{~N}-\mathrm{H}-\mathrm{O} / \mathrm{GLU}-166 / 2.110 \\
\mathrm{~N}-\mathrm{H}-\mathrm{O} / \mathrm{GLY}-143 / 2.577\end{array}$ \\
\hline $\begin{array}{l}\text { Constituents of } \\
\text { pungent ketones, } \\
\text { which result in the } \\
\text { strong aroma of ginger }\end{array}$ & Zingiber officinale & $\begin{array}{l}\text { Gingerol } \\
\text { Shogaol }\end{array}$ & $\begin{array}{l}\mathrm{C}_{17} \mathrm{H}_{26} \mathrm{O}_{4} \\
\mathrm{C}_{17} \mathrm{H}_{24} \mathrm{O}_{3}\end{array}$ & $\begin{array}{c}\mathrm{O}-\mathrm{H} / \mathrm{THR}-190 / 2.026 \\
\mathrm{~N}-\mathrm{H}-\mathrm{O} / \mathrm{GLY}-143 / 2.289 \\
\mathrm{~N}-\mathrm{H}-\mathrm{O} / \mathrm{THR}-26 / 2.398 \\
\mathrm{O}-\mathrm{H} / \mathrm{THR}-24 / 2.345\end{array}$ \\
\hline Red onion & Allium cepa & Quercetin & $\mathrm{C}_{15} \mathrm{H}_{10} \mathrm{O}_{7}$ & O-H/THR-26/1.936 \\
\hline Tulsi leaves & Ocimum sanctum & $\begin{array}{l}\text { Ursolic acid } \\
\text { Apigenin }\end{array}$ & $\begin{array}{l}\mathrm{C}_{30} \mathrm{H}_{48} \mathrm{O}_{3} \\
\mathrm{C}_{15} \mathrm{H}_{10} \mathrm{O}_{5}\end{array}$ & $\begin{array}{c}\text { N-H-O/GLY-143/2.330 } \\
\text { O-H/THR-26/1.994 }\end{array}$ \\
\hline $\begin{array}{l}\text { Cannabis extracts } \\
\text { Isolated from the plants }\end{array}$ & Cannabis sativa & Cannabidiol & $\mathrm{C}_{21} \mathrm{H}_{30} \mathrm{O}_{2}$ & N-H-O/GLY-143/2.325 \\
\hline $\begin{array}{l}\text { of both the black and } \\
\text { white pepper grains }\end{array}$ & Piper nigrum & Piperine & $\mathrm{C}_{17} \mathrm{H}_{19} \mathrm{NO}_{3}$ & N-H-O/THR-26/2.529 \\
\hline
\end{tabular}

On the other hand, an in silico molecular docking study on thirty-six phytochemical compounds showed high binding affinities for betulinic acid $(-10.0 \mathrm{Kcal} / \mathrm{mol})$, silibinin $(-9.13 \mathrm{Kcal} / \mathrm{mol})$, oleanolic acid $(-9.08 \mathrm{Kcal} / \mathrm{mol})$, and epigallocatechin-3-gallate $(-8.51 \mathrm{Kcal} / \mathrm{mol})$. These results suggested that the medicinal plants containing the mentioned compounds are potential candidates against Covid-19 [306].

\section{Biotechnological Production of Vaccines}

At time of writing of this document, no antiviral medicines have been proven to be effective against Covid-19 [307]. As mentioned earlier, remdesivir and hydroxychloroquine have been documented as the most reliable candidates against SARS-CoV [308]. On the other hand, a lot of efforts have been made to develop monoclonal antibodies and to evaluate receptor blockers [309]. Additionally, the use of transfusions by employing the plasma of recovered donor from the SARS-CoV virus infection is under assessment [310]. Over the last few decades, therapeutic vaccines have been revealed as the most effective tool against infectious diseases [311]. Due to the high transmissibility of SARS-CoV, the discovery of novel vaccines is an urgent target to tackle this pathogen [312]. A traditional way to generate vaccine is the method of inactivated vaccines, which can be made with SARS-CoV-2 virions previously inactivated by physical or chemical treatments [313]. Currently, an attenuated vaccine that is generated by reducing the microbial virulence of a 
pathogen is known [314]. Biotechnology is mostly applied to generate vaccines in three ways: the separation of a pure antigen using a specific monoclonal antibody, the synthesis of an antigen with the assistance of a cloned gene, and the synthesis of peptides to be used as vaccines. Furthermore, producing active pharmaceutical chemical compounds in genetically modified organisms is a novel application of biotechnology achieved by molecular pharming or hairy root technologies.

\subsection{Molecular Pharming: A Mature Technology to Produce Plant-Derived Pharmaceutical Products}

Molecular pharming is one of the biotechnology tools that involves the application of various plant species for the production of recombinant proteins, which include enzymes, hormones, vaccines, and antibodies [315] (Figure 4).

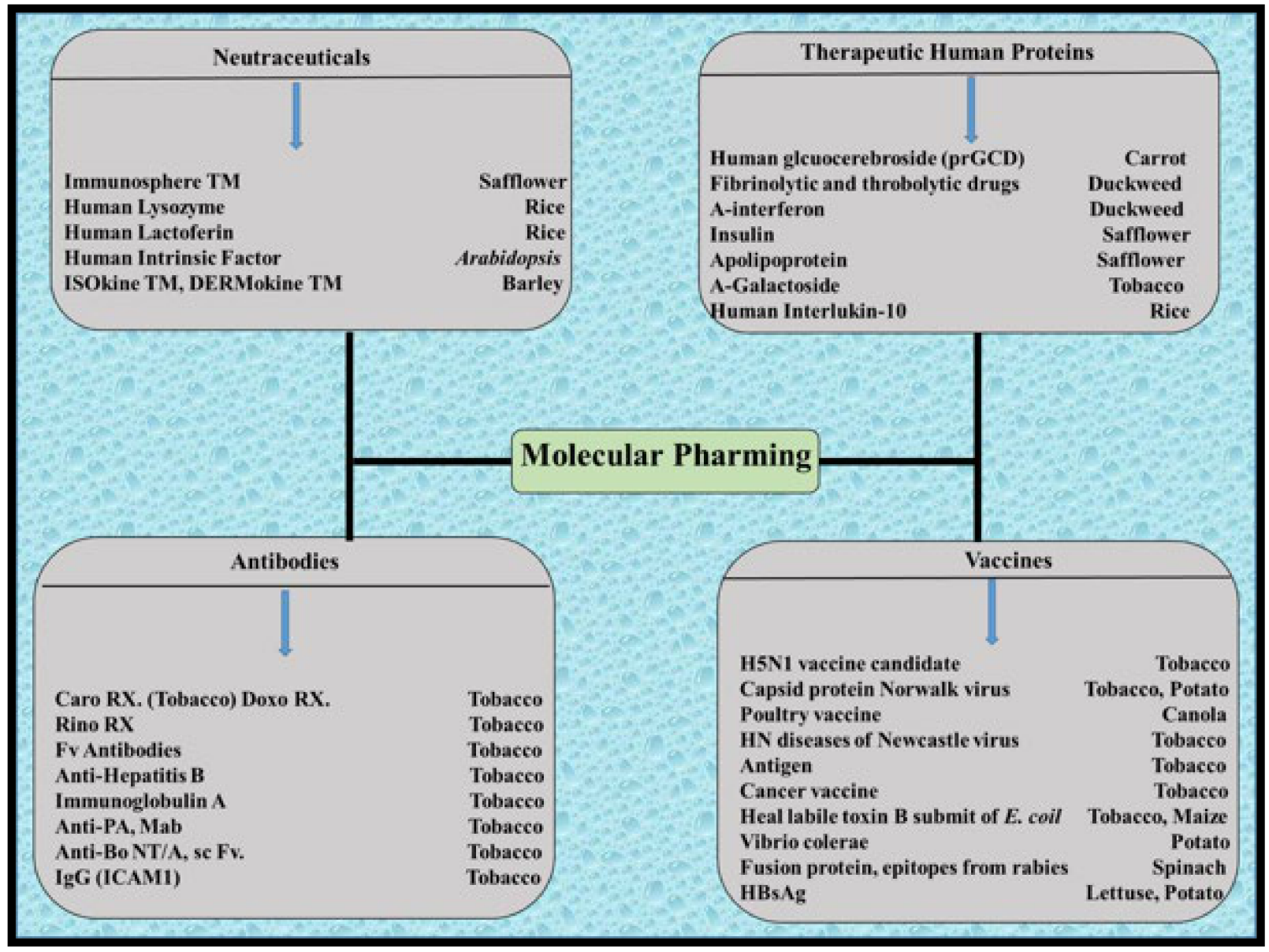

Figure 4. Plant molecular pharming products in different plants.

Over the last few decades, a lot of efforts have been made to produce different bioactive compounds and proteins in high yield through plant genetic engineering approaches [316]. The molecular pharming platform has several advantages over other transgenic systems such as a low overall cost, a high scale-up capacity, safety, high product quality, and the ability of post-translational modifications [317]. In 2005, Pogrebnyak and colleagues [17] tried to develop a recombinant vaccine against SARS by expressing the N-terminal fragment of the SARS-CoV S protein (S1) in tomatoes and low-nicotine tobacco plants. The results of their experiment showed the high expression of recombinant S1 protein in transgenic lines. The production of plant-derived antigens significantly enhanced the levels of SARS-CoV-specific IgA after the oral ingestion of tomato fruits expressing the S1 protein. Sera of mice parenterally primed with tobacco-derived S1 protein revealed the presence of SARS-CoV-specific IgG as observed with Western blot and ELISA anal- 
ysis. Two companies have announced their effort to produce plant-derived antibodies and vaccines against SARS-CoV-2. Soon after reporting the SARS-CoV-2 virus S protein, Medicago Inc. (www.medicago.com/en/pipeline/, the accessed date: 2 December 2020) announced VLP production in a transient gene expression system. Based on estimation, this company should be able to produce an attractive production capacity of VLP based vaccines (10 million doses). This amount of plant-derived vaccine can immunize approximately 10 million US adults who are at severe risk of critical illness or death if infected with SARSCoV-2. Furthermore, developing epitope-based vaccines is reported to reduce disease possibility. Kentucky Bioprocessing (www.kentuckybioprocessing.com, the accessed date: 2 December 2020), protalix (www.protalix.com, the accessed date: 2 December 2020), Greenovation Biopharmaceuticals (www.greenovation.com, the accessed date: 2 December 2020), Ventria (www.ventria.com, the accessed date: 2 December 2020), Nomad www.nomadbioscience.com, the accessed date: 2 December 2020), and iBio Inc. ( www.ibioinc.com/pipeline, the accessed date: 2 December 2020) are other companies that are making efforts to produce a VLP vaccine. On the other hand, academic institutions such as the Infectious Disease Research Centre at Laval University and Medicago have joined hands together to develop plant-derived pipelines. Simultaneously, several institutes and universities from different countries including Thailand, Mexico, South Korea, South Africa, the UK, Germany, and the US are working on the production of plant-derived products through molecular farming technology against the Covid-19. It is believed that producing a stable plant-derived product through molecular farming takes a long time, and a major concern is that these products are not as approachable as expected in response to the pandemic. However, applying transient systems should be a reliable, fast, and efficient tool to overcome these barriers. Due to the high adaptability and potential of the SARS-CoV-2 virus, it seems that oral vaccines like plant molecular farming products are the most reliable weapons against the SARS-CoV-2 virus [318].

\subsection{Hairy Root Culture: A Reliable Method of Producing Pharmaceutical Products}

Hairy roots, which are induced by Rhizobium rhizogenes (syn. Agrobacterium rhizogenes), a Gram-negative bacterium, comprise an important biotechnological system to induce bioactive compounds from plants. Hairy root cultures employ organs instead of undifferentiated cells, thereby providing better yields than cell culture or natural plant roots [318,319]. Other advantages include biochemical and genetic stability, ease of preservation, and rapid growth on hormone-free media. Different Agrobacterium strains, which are divergent in terms of virulence, the growth rate of transformed cells, their morphology, and secondary metabolite production, are generally employed to induce hairy roots from explants in different plant species. It has been recognized that Agrobacterium strains have different abilities to promote the production of bioactive compounds in hairy root cultures [302,320,321]. This is mainly due to the differential expression and integration of T-DNA genes into the plant genome [302,321]. Therefore, the selection of an effective Agrobacterium strain for hairy root induction and secondary compound accumulation is noticeably dependent on plant species and must be empirically figured out [302,322] (Figure 5). 


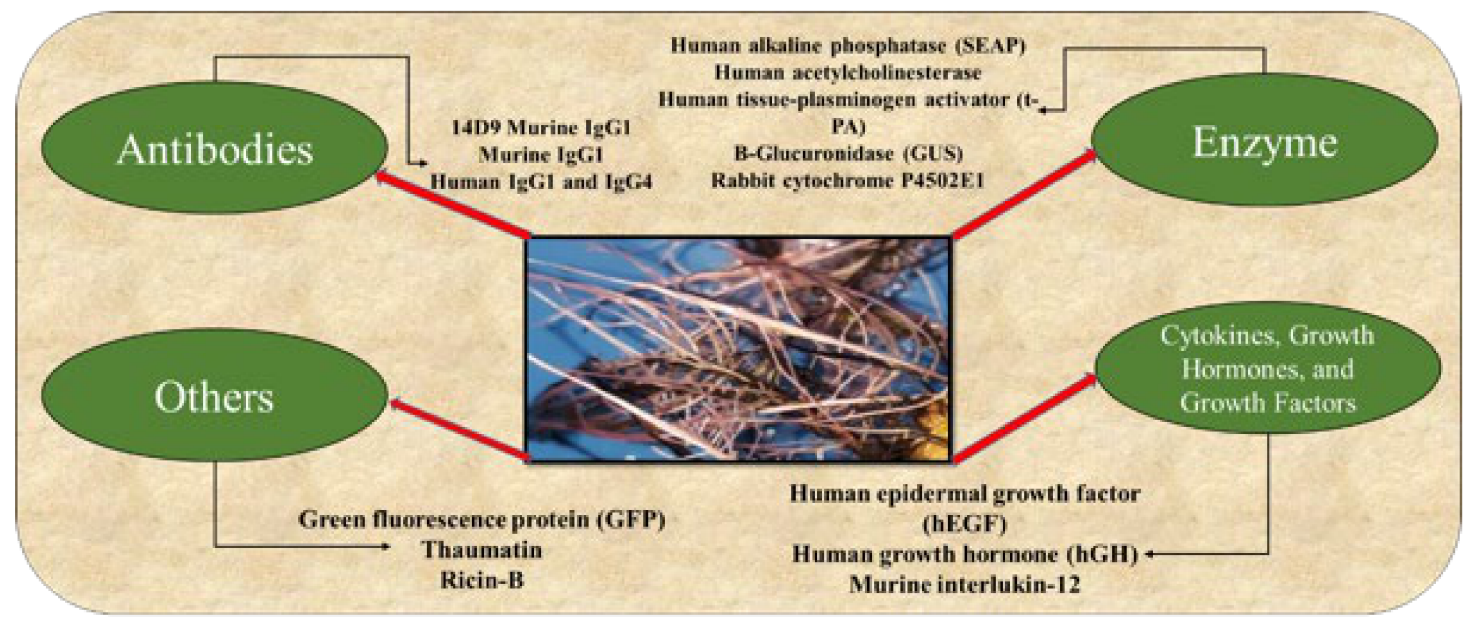

Figure 5. Hairy root cultures used to produce recombinant proteins. The final products of hairy root systems have been used to produce cytokines, vaccines, antibodies, enzymes, and other therapeutic proteins. These systems have various pros and cons, and these points should be considered when attempting to choose the best platforms.

Mentha spicata, commonly known as spearmint or garden mint, is known to possess antiviral properties due to the presence of high amounts of phenolic compounds such as rosmarinic acid, chlorogenic acid, caffeic acid, lithospermic acid B, and cinnamic acid. The production of phenolic acids in $M$. spicata was compared among hairy roots induced from five different $A$. rhizogenes strains: ATCC15834, 9534, A13, A4, and R318. It was found that A. rhizogenes strain 9534 efficiently produced caffeic acid, lithospermic acid B, cinnamic acid, rosmarinic acid, and chlorogenic acid $\left(106.76,60.22,44.02,20.08\right.$, and $13.53 \mu \mathrm{g} \mathrm{g}^{-1}$ DW, respectively), but hairy root induction was effective with A13 and R318 [323-326].

It has been shown in many plant species that transformation by $A$. rhizogenes strains leads to the modification of metabolic pathways. As a result, transformed roots differ in their chemical profiles from normal roots, which shows that Ri T-DNA interferes with the biosynthesis of secondary metabolites [324-326].

The effects of different media (Schenk and Hildebrandt (SH), Woody plant medium (WPM), and Gamborg (B5)) and lighting conditions (light or dark) on biomass accumulation and secondary metabolite production in hairy root line (RC3) were examined in Rhaponticum carthamoides [326]. The WPM supported the highest biomass $\left(93 \mathrm{~g} \mathrm{~L}^{-1}\right.$ of the fresh weight after 35 days) under periodic light. Additionally, the higher production of caffeoylquinic acids and their derivatives was observed in hairy roots grown in the light as compared to untransformed roots. The biosynthesis of flavonoid glycosides such as quercetagetin, quercetin, luteolin, and patuletin hexoside from transformed roots was also found in light conditions [326]. Balasubramanian et al. [327] showed that time, number of co-cultivation days, acetosyringone concentration, media type, media strength, and sucrose concentration affect hairy root production for the improvement of quercetin content in Raphanus sativus (radish). Explants infected with an A. rhizogenes MTCC 2364 suspension for $10 \mathrm{~min}$ and co-cultivated in a 1/2 MS medium containing acetosyringone $(100 \mu \mathrm{M})$ for two days displayed a maximum percentage of hairy root induction (77.6\%). Hairy roots were found to produce higher amounts of quercetin $\left(114.8 \mathrm{mg} \mathrm{g}^{-1}\right)$ compared to the auxin-induced roots of non-transformed radish. Similarly, higher amounts of phenolic compounds including pyrogallol, hesperidin, naringenin, and formononetin were observed in Polygonum multiflorum hairy roots compared to untransformed roots [328].

Because it has been found that both endogenous and exogenous factors affect resveratrol production in the hairy root culture of grapes and increase resveratrol production, this strategy could be useful [329]. Different features like the type of explants, seedling age, concentration of the bacterial inoculum, and inoculation time have been studied to improve the efficiency of hairy root formation and resveratrol production. Hairy roots induced by $A$. rhizogenes strain A4 from internodes of Vitis vinifera subsp. sylvesteris (W16) were found to 
produce the highest amount of resveratrol (31-fold higher than that of control root) [329]. In Scutellaria baicalensis, hairy roots grown in a full-strength MS medium produced a 2.5 -fold higher amount of resveratrol than those grown in a half-strength B5 medium. The addition of auxin (indole acetic acid (IAA)) at $0.1 \mathrm{mg} / \mathrm{L}$ into the medium resulted in the highest accumulation of resveratrol $[323,330]$.

The elicitation of hairy root cultures by biotic/abiotic stressors or chemicals for the exploitation of genetic engineering manipulation can significantly increase the amount of the desired secondary compound [331]. Different elicitors such as UV radiation, methyl jasmonate (MeJA), jasmonic acid, gibberellic acid, sodium acetate, salicylic acid, acetic acid, ammonium nitrate, chitosan, and cyclodextrins have been employed to stimulate the production of secondary metabolites in hairy roots [332]. Chitosan, methyl jasmonate, and yeast extract have been employed to enhance the glycyrrhizin contents in Glycyrrhiza species. Glycyrrhizin, an active component of licorice roots, is known to be effective against several viral diseases including HIV and SARS [104]. It has been reported that glycyrrhizin also inhibits the adsorption and penetration of the virus-early steps of the replicative cycle in addition to the inhibition of virus replication [104]. Elicitation with $100 \mu \mathrm{M}$ MeJA enhanced glycyrrhizin content (5.7 times higher than the control) after five days of treatment in G. inflata hairy roots [333]. MeJA (at $100 \mu \mathrm{M}$ concentration) was found to be the most effective elicitor for increasing glycyrrhizin production up to $108.9 \pm 1.15$ $\mu \mathrm{g} \mathrm{g}^{-1} \mathrm{DW}$ after five days of elicitation [334].

Elicitation with sodium acetate for $24 \mathrm{~h}$ resulted in the 60 -fold induction and secretion of trans-resveratrol into a peanut hairy root culture medium [201]. The authors [335] studied the effect of different concentrations of abiotic elicitors including MeJA, sodium acetate, acetic acid, and ammonium nitrate. Their results showed that treatment of hairy roots with $3 \mathrm{mM}$ acetic acid or $50 \mu \mathrm{M}$ methyl jasmonate resulted in the highest or lowest amounts of hairy root biomass and resveratrol content, respectively.

\section{Conclusions}

The current review provides an overview of employing ethnomedicinal herbs to treat respiratory diseases. It has been shown that plant biodiversity can be a source of bioactive compounds of different natures, such as terpenes, stilbenes, coumarins, flavone glycosides, and alkaloids. The most common of these are lectins, quercetin, resveratrol, glycyrrhizin, and curcumin. It has been found that qualitative and quantitative biochemical specification can vary between representatives of the same family. Such a literature analysis could be used to choose an appropriate plant model for a specific region with specific needs. With the intervention of biotechnological tools such as hairy root transformation, it is possible to obtain compounds of interest in a higher amount. Plant-based production systems comprise another alternative for molecular farming technology. This review not only provides a reference point for the screening of plants against viral diseases but can also be useful for practical implications and applications.

\section{Future Directions}

The present review describes the potential of plant or plant-based compounds for treating antiviral diseases, especially emphasizing SARS-CoV. The urgency of this work is that new viruses may appear in the near future. There is a gap between information regarding the complete understanding of the mechanism of action of plant-based compounds and their execution as treatments of viral diseases. Both empirical and rational approaches are required to gain insight into the phytochemical evaluation and validation of plant-based compounds. Critical knowledge of genetic, molecular, and biochemical processes under in situ conditions could be helpful to better control the accumulation of natural products. Future studies may be targeted at understanding the mechanisms of action of complex plant extracts and isolated plant-derived compounds from different biosynthetic pathways. Molecular docking studies and in silico analyses of extracted compounds from different herbal plants including aloe vera and giloy could be beneficial for further investigations. 
By employing biotechnological tools like hairy root cultures and molecular pharming, it is quite possible to enhance the production of the compounds of interest. No doubt, careful preclinical and clinical procedures need to be followed before coming to the validation of plant-based drugs or vaccines against these viral diseases. This would help to pave the way and take important steps to combat this life-threatening and deadly disease.

Author Contributions: Conceptualization, R.A. (Rambod Abiri), and S.M.; methodology, R.A. (Rambod Abiri), O.S. and R.A. (Ramin Abiri); investigation, S.M., R.A. (Rambod Abiri), H.A.-H., S.M. and R.A. (Ramin Abiri); resources, H.A.-H.; writing-original draft preparation, R.A. (Rambod Abiri), O.S., S.M., R.A. (Ramin Abiri), E.B.d.A.J., S.K.S. and R.R.J.A.; writing-review and editing, E.B.d.A.J.; S.K.S., V.P.B. and S.M.; visualization, R.A. (Ramin Abiri), S.M. and V.P.B.; supervision, H.A.-H., V.P.B. and S.M. All authors have read and agreed to the published version of the manuscript.

Funding: This review paper received no external funding.

Institutional Review Board Statement: Not applicable.

Informed Consent Statement: Not applicable.

Data Availability Statement: Not applicable.

Acknowledgments: We thank Universiti Putra Malaysia (UPM) and Federal University of Maranhão for supporting the present study.

Conflicts of Interest: The authors report no declarations of interest.

\section{References}

1. Amber, R.; Adnan, M.; Tariq, A.; Mussarat, S. A review on antiviral activity of the Himalayan medicinal plants traditionally used to treat bronchitis and related symptoms. J. Pharm. Pharmacol. 2017, 69, 109-122. [CrossRef] [PubMed]

2. Zhu, N.; Zhang, D.; Wang, W.; Li, X.; Yang, B.; Song, J.; Zhao, X.; Huang, B.; Shi, W.; Lu, R.; et al. A Novel Coronavirus from Patients with Pneumonia in China, 2019. N. Engl. J. Med. 2020, 382, 727-733. [CrossRef] [PubMed]

3. Peeri, N.C.; Shrestha, N.; Rahman, S.; Zaki, R.; Tan, Z.; Bibi, S.; Baghbanzadeh, M.; Aghamohammadi, N.; Zhang, W.; Haque, U. The SARS, MERS and novel coronavirus (COVID-19) epidemics, the newest and biggest global health threats: What lessons have we learned? Int. J. Epidemiol. 2020, 49, 717-726. [CrossRef] [PubMed]

4. Li, J.; Liu, W. Puzzle of highly pathogenic human coronaviruses (2019-nCoV). Protein Cell 2020, 11, 235-238. [CrossRef] [PubMed]

5. Sathya, B.; Velpandian, V.; Ramani, M.; Kumar, M.P. A primitive approach on review of Siddha herbs, herbo-mineral formulation exhibiting antiviral activity. Int. J. Pharm. Bio. Sci. 2014, 5, 138-147.

6. Forman, R.; Shah, S.; Jeurissen, P.; Jit, M.; Mossialos, E. COVID-19 vaccine challenges: What have we learned so far and what remains to be done? Health Policy 2021, 125, 553-567. [CrossRef] [PubMed]

7. Khan, A.; Khan, M.; Saleem, S.; Babar, Z.; Ali, A.; Khan, A.A.; Sardar, Z.; Hamayun, F.; Ali, S.S.; Wei, D.-Q. Phylogenetic Analysis and Structural Perspectives of RNA-Dependent RNA-Polymerase Inhibition from SARs-CoV-2 with Natural Products. Interdiscip. Sci. Comput. Life Sci. 2020, 12, 335-348. [CrossRef]

8. Khan, A.; Tahir Khan, M.; Saleem, S.; Junaid, M.; Ali, A.; Shujait Ali, S.; Khan, M.; Wei, D.Q. Structural insights into the mechanism of RNA recognition by the N-terminal RNA-binding domain of the SARS-CoV-2 nucleocapsid phosphoprotein. Comput. Struct. Biotechnol. J. 2020, 18, 2174-2184. [CrossRef]

9. Alrasheid, A.A.; Babiker, M.Y.; Awad, T.A. Evaluation of certain medicinal plants compounds as new potential inhibitors of novel corona virus (COVID-19) using molecular docking analysis. Silico Pharmacol. 2021, 9, 10. [CrossRef]

10. Khan, M.T.; Zeb, M.T.; Ahsan, H.; Ahmed, A.; Ali, A.; Akhtar, K.; Malik, S.I.; Cui, Z.; Ali, S.; Khan, A.S.; et al. SARS-CoV-2 nucleocapsid and Nsp3 binding: An in silico study. Arch. Microbiol. 2021, 203, 59-66. [CrossRef]

11. Khan, M.T.; Ali, A.; Wang, Q.; Irfan, M.; Khan, A.; Zeb, M.T.; Zhang, Y.-J.; Chinnasamy, S.; Wei, D.-Q. Marine natural compounds as potents inhibitors against the main protease of SARS-CoV-2-A molecular dynamic study. J. Biomol. Struct. Dyn. 2020, 1-11. [CrossRef]

12. Wang, X.; Liu, Z. Prevention and treatment of viral respiratory infections by traditional Chinese herbs. Chin. Med. J. 2014, 127, 1344-1350.

13. Remali, J.; Aizat, W.M. A Review on Plant Bioactive Compounds and Their Modes of Action Against Coronavirus Infection. Front. Pharmacol. 2021, 11, 589044. [CrossRef]

14. Chojnacka, K.; Witek-Krowiak, A.; Skrzypczak, D.; Mikula, K.; Młynarz, P. Phytochemicals containing biologically active polyphenols as an effective agent against Covid-19-inducing coronavirus. J. Funct. Foods 2020, 73, 104146. [CrossRef]

15. Siddiqui, M.H.; Alamri, S.; Al-Whaibi, M.H.; Hussain, Z.; Ali, H.M.; El-Zaidy, M.E. A mini-review of anti-hepatitis B virus activity of medicinal plants. Biotechnol. Biotechnol. Equip. 2016, 31, 9-15. [CrossRef] 
16. Li, S.-Y.; Chen, C.; Zhang, H.-Q.; Guo, H.-Y.; Wang, H.; Wang, L.; Zhang, X.; Hua, S.-N.; Yu, J.; Xiao, P.-G. Identification of natural compounds with antiviral activities against SARS-associated coronavirus. Antivir. Res. 2005, 67, 18-23. [CrossRef]

17. Pogrebnyak, N.; Golovkin, M.; Andrianov, V.; Spitsin, S.; Smirnov, Y.; Egolf, R.; Koprowski, H. Severe acute respiratory syndrome (SARS) S protein production in plants: Development of recombinant vaccine. Proc. Natl. Acad. Sci. USA 2005, 102, 9062-9067. [CrossRef]

18. Li, H.-Y.; Ramalingam, S.; Chye, M.-L. Accumulation of recombinant SARS-CoV spike protein in plant cytosol and chloroplasts indicate potential for development of plant-derived oral vaccines. Exp. Biol. Med. 2006, 231, 1346-1352. [CrossRef]

19. Vignuzzi, M.; López, C.B. Defective viral genomes are key drivers of the virus-host interaction. Nat. Microbiol. 2019, 4, 1075-1087. [CrossRef]

20. Haslberger, A.; Jacob, U.; Hippe, B.; Karlic, H. Mechanisms of selected functional foods against viral infections with a view on COVID-19: Mini review. Funct. Foods Heal. Dis. 2020, 10, 195. [CrossRef]

21. Leung, A.K.; Hon, K.; Leong, K.; Sergi, C. Measles: A disease often forgotten but not gone. Hong Kong Med. J. 2018, 24, 512-520. [CrossRef]

22. Roy, P. Bluetongue Virus Proteins and Particles and Their Role In Virus Entry, Assembly, And Release. Int. Rev. Cytol. 2005, 64, 69-123. [CrossRef]

23. Li, T.; Peng, T. Traditional Chinese herbal medicine as a source of molecules with antiviral activity. Antivir. Res. 2013, 97, 1-9. [CrossRef]

24. Xu, Z.; Peng, C.; Shi, Y.; Zhu, Z.; Mu, K.; Wang, X.; Zhu, W. Nelfinavir was predicted to be a potential inhibitor of 2019-nCov main protease by an integrative approach combining homology modelling, molecular docking and binding free energy calculation. bioRxiv 2020. [CrossRef]

25. Rodríguez-Morales, A.J.; MacGregor, K.; Kanagarajah, S.; Patel, D.; Schlagenhauf, P. Going global-Travel and the 2019 novel coronavirus. Travel Med. Infect. Dis. 2020, 33, 101578. [CrossRef]

26. Gould Maule, G. Investigation of Host Factors Required for Lymphocytic Choriomeningitis Virus Entry. Master's Thesis, University of Ottawa, Ottawa, ON, Canada, 2019. [CrossRef]

27. Coutard, B.; Valle, C.; De Lamballerie, X.; Canard, B.; Seidah, N.; Decroly, E. The spike glycoprotein of the new coronavirus 2019-nCoV contains a furin-like cleavage site absent in CoV of the same clade. Antivir. Res. 2020, 176, 104742. [CrossRef]

28. Vankadari, N.; Wilce, J.A. Emerging COVID-19 coronavirus: Glycan shield and structure prediction of spike glycoprotein and its interaction with human CD26. Emerg. Microbes Infect. 2020, 9, 601-604. [CrossRef] [PubMed]

29. Sargiacomo, C.; Sotgia, F.; Lisanti, M.P. COVID-19 and chronological aging: Senolytics and other anti-aging drugs for the treatment or prevention of corona virus infection? Aging 2020, 12, 6511-6517. [CrossRef] [PubMed]

30. Ortiz-Prado, E.; Simbaña-Rivera, K.; Gómez-Barreno, L.; Rubio-Neira, M.; Guaman, L.P.; Kyriakidis, N.C.; López-Cortés, A. Clinical, molecular and epidemiological characterization of the SARS-CoV2 virus and the Coronavirus disease 2019 (COVID-19), a comprehensive literature review. Diagn. Microbiol. Infect. Dis. 2020, 98, 115094. [CrossRef] [PubMed]

31. Liu, X.; Wang, X.-J. Potential inhibitors against 2019-nCoV coronavirus M protease from clinically approved medicines. J. Genet. Genom. 2020, 47, 119-121. [CrossRef]

32. Chang, K.-O.; Kim, Y.; Lovell, S.; Rathnayake, A.D.; Groutas, W.C. Antiviral Drug Discovery: Norovirus Proteases and Development of Inhibitors. Viruses 2019, 11, 197. [CrossRef]

33. Li, J.-Y.; You, Z.; Wang, Q.; Zhou, Z.-J.; Qiu, Y.; Luo, R.; Ge, X.-Y. The epidemic of 2019-novel-coronavirus (2019-nCoV) pneumonia and insights for emerging infectious diseases in the future. Microbes Infect. 2020, 22, 80-85. [CrossRef]

34. Wang, Z.; Chen, X.; Lu, Y.; Chen, F.; Zhang, W. Clinical characteristics and therapeutic procedure for four cases with 2019 novel coronavirus pneumonia receiving combined Chinese and Western medicine treatment. Biosci. Trends 2020, 14, 64-68. [CrossRef]

35. Loizzo, M.R.; Saab, A.M.; Tundis, R.; Statti, G.A.; Menichini, F.; Lampronti, I.; Gambari, R.; Cinatl, J.; Doerr, H.W. Phytochemical Analysis andin vitro Antiviral Activities of the Essential Oils of Seven Lebanon Species. Chem. Biodivers. 2008, 5, 461-470. [CrossRef]

36. Khaerunnisa, S.; Kurniawan, H.; Awaluddin, R.; Suhartati, S.; Soetjipto, S. Potential inhibitor of COVID-19 main protease (Mpro) from several medicinal plant compounds by molecular docking study. Preprints 2020. [CrossRef]

37. Zimmerman, A.E.; Howard-Varona, C.; Needham, D.M.; John, S.G.; Worden, A.Z.; Sullivan, M.B.; Waldbauer, J.R.; Coleman, M.L. Metabolic and biogeochemical consequences of viral infection in aquatic ecosystems. Nat. Rev. Genet. 2020, 18, 21-34. [CrossRef]

38. Feng, Y.; Gao, G.F. Towards our understanding of SARS-CoV, an emerging and devastating but quickly conquered virus. Comp. Immunol. Microbiol. Infect. Dis. 2007, 30, 309-327. [CrossRef]

39. Kpewou, D.E. Antioxidant Micronutrients Intake in People Living with HIV: Implications on Serum Levels and Liver Function. Master's Thesis, Kwame Nkrumah University of Science and Technology, Kumasi, Ghana, October 2017.

40. Chantrill, B.H.; Coulthard, C.E.; Dickinson, L.; Inkley, G.W.; Morris, W.; Pyle, A.H. The Action of Plant Extracts on a Bacteriophage of Pseudomonas pyocyanea and on Influenza A Virus. J. Gen. Microbiol. 1952, 6, 74-84. [CrossRef]

41. Debiaggi, M.; Pagani, L.; Cereda, P.M.; Landini, P.; Romero, E. Antiviral activity of Chamaecyparis lawsoniana extract: Study with herpes simplex virus type 2. Microbiology 1988, 11, 55-61.

42. Vermani, K.; Garg, S. Herbal medicines for sexually transmitted diseases and AIDS. J. Ethnopharmacol. 2002, 80, 49-66. [CrossRef]

43. Asres, K.; Bucar, F. Anti-HIV activity against immunodeficiency virus type 1 (HIV-I) and type II (HIV-II) of compounds isolated from the stem bark of Combretum molle. Ethiop. Med. J. 2005, 43, 15-20. [PubMed] 
44. Kotwal, G.J.; Kaczmarek, J.N.; Leivers, S.; Ghebremariam, Y.T.; Kulkarni, A.P.; Bauer, G.; De Beer, C.; Preiser, W.; Mohamed, A.R. Anti-HIV, Anti-Poxvirus, and Anti-SARS Activity of a Nontoxic, Acidic Plant Extract from the Trifollium Species SecometV/anti-Vac Suggests That It Contains a Novel Broad-Spectrum Antiviral. Ann. N. Y. Acad. Sci. 2005, 1056, 293-302. [CrossRef] [PubMed]

45. Kwon, D.H.; Kwon, H.Y.; Kim, H.J.; Chang, E.J.; Kim, M.B.; Yoon, S.K.; Song, E.Y.; Yoon, D.Y.; Lee, Y.H.; Choi, I.S.; et al. Inhibition of hepatitis B virus by an aqueous extract of Agrimonia eupatoria L. Phytotherapy Res. 2005, 19, 355-358. [CrossRef] [PubMed]

46. Huang, K.-L.; Lai, Y.-K.; Lin, C.-C.; Chang, J.-M. Inhibition of hepatitis B virus production byBoehmeria nivearoot extract in HepG2 2.2.15 cells. World J. Gastroenterol. 2006, 12, 5721-5725. [CrossRef]

47. Webster, D.; Taschereau, P.; Lee, T.D.; Jurgens, T. Immunostimulant properties of Heracleum maximum Bartr. J. Ethnopharmacol. 2006, 106, 360-363. [CrossRef]

48. Shanti, B.M. Perspective of Potential Plants for Medicine from Rajasthan, India. Int. J. Pharm. Res. 2016, 7, 1-6.

49. Otake, T.; Mori, H.; Morimoto, M.; Ueba, N.; Sutardjo, S.; Kusumoto, I.T.; Hattori, M.; Namba, T. Screening of Indonesian plant extracts for anti-human immunodeficiency virus-Type 1 (HIV-1) activity. Phytotherapy Res. 1995, 9, 6-10. [CrossRef]

50. Rege, A.; Chowdhary, A.S. Evaluation of Ocimum sanctum and Tinospora cordifolia as probable HIV protease inhibitors. Int. J. of Pharm. Sci. Rev. Res. 2014, 25, 315-318.

51. Thayil Seema, M.; Thyagarajan, S. Methanol and aqueous extracts of Ocimum kilimandscharicum (Karpuratulasi) inhibits HIV-1 reverse transcriptase in vitro. Int. J. Pharmacogn. Phytochem. Res. 2016, 8, 1099-1103.

52. Yu, Y.-B. The extracts of Solanum nigrum L. for inhibitory effects on HIV-1 and its essential enzymes. Korean J. Orient Med. Prescr. 2004, 10, 119-126.

53. Nair, R. HIV-1 reverse transcriptase inhibition by Vitex negundo L. leaf extract and quantification of flavonoids in relation to anti-HIV activity. J. Cell. Mol. Biol. 2012, 10, 53-59.

54. Castro, F.; Cardoso, A.; Gonçalves, R.M.; Serre, K.; Oliveira, M.J. Interferon-Gamma at the Crossroads of Tumor Immune Surveillance or Evasion. Front. Immunol. 2018, 9, 847. [CrossRef]

55. Ryu, Y.B.; Jeong, H.J.; Kim, J.H.; Kim, Y.M.; Park, J.-Y.; Kim, D.; Naguyen, T.T.H.; Park, S.-J.; Chang, J.S.; Park, K.H. Biflavonoids from Torreya nucifera displaying SARS-CoV 3CLpro inhibition. Bioorg. Med. Chem. 2010, 18, 7940-7947. [CrossRef]

56. Park, J.-Y.; Ko, J.-A.; Kim, D.W.; Kim, Y.M.; Kwon, H.-J.; Jeong, H.J.; Kim, C.Y.; Park, K.H.; Lee, W.S.; Ryu, Y.B. Chalcones isolated fromAngelica keiskeiinhibit cysteine proteases of SARS-CoV. J. Enzym. Inhib. Med. Chem. 2016, 31, 23-30. [CrossRef]

57. Chen, Z.; Ye, S.-Y.; Yang, Y.; Li, Z.-Y. A review on charred traditional Chinese herbs: Carbonization to yield a haemostatic effect. Pharm. Biol. 2019, 57, 498-506. [CrossRef]

58. Wen, C.-C.; Shyur, L.-F.; Jan, J.-T.; Liang, P.-H.; Kuo, C.-J.; Arulselvan, P.; Wu, J.-B.; Kuo, S.-C.; Yang, N.-S. Traditional Chinese medicine herbal extracts of Cibotium barometz, Gentiana scabra, Dioscorea batatas, Cassia tora, and Taxillus chinensis inhibit SARS-CoV replication. J. Tradit. Complement. Med. 2011, 1, 41-50. [CrossRef]

59. Kim, D.W.; Seo, K.H.; Curtis-Long, M.J.; Oh, K.Y.; Oh, J.-W.; Cho, J.K.; Lee, K.H.; Park, K.H. Phenolic phytochemical displaying SARS-CoV papain-like protease inhibition from the seeds of Psoralea corylifolia. J. Enzym. Inhib. Med. Chem. 2013, $29,59-63$. [CrossRef]

60. Zhen, H.; Fang, F.; Ye, D.-Y.; Shu, S.-N.; Zhou, Y.-F.; Dong, Y.-S.; Nie, X.-C.; Li, G. Experimental study on the action of allitridin against human cytomegalovirus in vitro: Inhibitory effects on immediate-early genes. Antivir. Res. 2006, 72, 68-74. [CrossRef]

61. Yu, M.-S.; Lee, J.; Lee, J.M.; Kim, Y.; Chin, Y.-W.; Jee, J.-G.; Keum, Y.-S.; Jeong, Y.-J. Identification of myricetin and scutellarein as novel chemical inhibitors of the SARS coronavirus helicase, nsP13. Bioorg. Med. Chem. Lett. 2012, 22, 4049-4054. [CrossRef]

62. Zhu, Q.-C.; Wang, Y.; Liu, Y.-P.; Zhang, R.-Q.; Li, X.; Su, W.-H.; Long, F.; Luo, X.-D.; Peng, T. Inhibition of enterovirus 71 replication by chrysosplenetin and penduletin. Eur. J. Pharm. Sci. 2011, 44, 392-398. [CrossRef]

63. Wen, C.-C.; Kuo, Y.-H.; Jan, J.-T.; Liang, P.-H.; Wang, S.-Y.; Liu, H.-G.; Lee, C.-K.; Chang, S.-T.; Kuo, C.-J.; Lee, S.-S.; et al. Specific Plant Terpenoids and Lignoids Possess Potent Antiviral Activities against Severe Acute Respiratory Syndrome Coronavirus. J. Med. Chem. 2007, 50, 4087-4095. [CrossRef]

64. Gao, Y.; Dong, X.; Kang, T.G. Activity of in vitro anti-influenza virus of arctigenin. Chin. Tradit. Herb. Drugs 2002, 33, 724-725.

65. Yi, L.; Li, Z.; Yuan, K.; Qu, X.; Chen, J.; Wang, G.; Zhang, H.; Luo, H.; Zhu, L.; Jiang, P.; et al. Small Molecules Blocking the Entry of Severe Acute Respiratory Syndrome Coronavirus into Host Cells. J. Virol. 2004, 78, 11334-11339. [CrossRef]

66. Zuo, G.-Y.; Li, Z.-Q.; Chen, L.-R.; Xu, X.-J. In Vitro Anti-HCV Activities of Saxifraga Melanocentra and its Related Polyphenolic Compounds. Antivir. Chem. Chemother. 2005, 16, 393-398. [CrossRef]

67. Zuo, G.; Li, Z.; Chen, L.; Xu, X. Activity of compounds from Chinese herbal medicine Rhodiola kirilowii (Regel) Maxim against HCV NS3 serine protease. Antivir. Res. 2007, 76, 86-92. [CrossRef]

68. Guo, Q.; Zhao, L.; You, Q.; Yang, Y.; Gu, H.; Song, G.; Lu, N.; Xin, J. Anti-hepatitis B virus activity of wogonin in vitro and in vivo. Antivir. Res. 2007, 74, 16-24. [CrossRef]

69. Zhou, Z.; Zhang, Y.; Ding, X.-R.; Chen, S.-H.; Yang, J.; Wang, X.-J.; Jia, G.-L.; Chen, H.-S.; Bo, X.-C.; Wang, S.-Q. Protocatechuic aldehyde inhibits hepatitis B virus replication both in vitro and in vivo. Antivir. Res. 2007, 74, 59-64. [CrossRef] [PubMed]

70. Wang, Y.-P.; Zhao, W.; Xue, R.; Zhou, Z.-X.; Liu, F.; Han, Y.-X.; Ren, G.; Peng, Z.-G.; Cen, S.; Chen, H.-S.; et al. Oxymatrine inhibits hepatitis B infection with an advantage of overcoming drug-resistance. Antivir. Res. 2011, 89, 227-231. [CrossRef] [PubMed]

71. Zhuang, M.; Jiang, H.; Suzuki, Y.; Li, X.; Xiao, P.; Tanaka, T.; Ling, H.; Yang, B.; Saitoh, H.; Zhang, L.; et al. Procyanidins and butanol extract of Cinnamomi Cortex inhibit SARS-CoV infection. Antivir. Res. 2009, 82, 73-81. [CrossRef] [PubMed] 
72. Park, J.-Y.; Jeong, H.J.; Kim, J.H.; Kim, Y.M.; Park, S.-J.; Kim, D.; Park, K.H.; Lee, W.S.; Ryu, Y.B. Diarylheptanoids from Alnus japonica Inhibit Papain-Like Protease of Severe Acute Respiratory Syndrome Coronavirus. Biol. Pharm. Bull. 2012, 35, $2036-2042$. [CrossRef]

73. Chin, L.W.; Cheng, Y.-W.; Lin, S.-S.; Lai, Y.-Y.; Lin, L.-Y.; Chou, M.-Y.; Yang, C.-C.; Chou, M.-C. Anti-herpes simplex virus effects of berberine from Coptidis rhizoma, a major component of a Chinese herbal medicine, Ching-Wei-San. Arch. Virol. 2010, 155, 1933-1941. [CrossRef]

74. Lee, J.S.; Kim, H.J.; Lee, Y.S. A new Anti-HIV Flavonoid Glucuronide fromChrysanthemum morifolium. Planta Medica 2003, 69, 859-861. [CrossRef]

75. Zhang, H.; Tan, G.T.; Hoang, V.D.; Van Hung, N.; Cuong, N.M.; Soejarto, D.D.; Pezzuto, J.M.; Fong, H.H.S. Natural Anti-HIV Agents. Part IV. Anti-HIV Constituents fromVaticacinerea1. J. Nat. Prod. 2003, 66, 263-268. [CrossRef]

76. Yang, X.-W.; Zhao, J.; Cui, Y.-X.; Liu, X.-H.; Ma, C.-M.; Hattori, M.; Zhang, L.-H. Anti-HIV-1 Protease Triterpenoid Saponins from the Seeds of Aesculuschinensis. J. Nat. Prod. 1999, 62, 1510-1513. [CrossRef]

77. Kuo, Y.H.; Li, S.Y.; Huang, R.L.; Wu, M.D.; Huang, H.C.; Lee, K.H. Schizarin B, C, D, and E, Four New Lignans from Kadsuram atsudai and Their Antihepatitis Activities. J. Nat. Prod. 2001, 64, 487-490. [CrossRef]

78. Kuo, Y.-C.; Kuo, Y.-H.; Lin, Y.-L.; Tsai, W.-J. Yatein from Chamaecyparis obtusa suppresses herpes simplex virus type 1 replication in HeLa cells by interruption the immediate-early gene expression. Antivir. Res. 2006, 70, 112-120. [CrossRef]

79. Cheng, H.-Y.; Lin, T.-C.; Yang, C.-M.; Wang, K.-C.; Lin, L.-T.; Lin, C.-C. Putranjivain A from Euphorbia jolkini inhibits both virus entry and late stage replication of herpes simplex virus type 2 in vitro. J. Antimicrob. Chemother. 2004, 53, 577-583. [CrossRef]

80. Kuo, Y.-C.; Lin, L.-C.; Tsai, W.-J.; Chou, C.-J.; Kung, S.-H.; Ho, Y.-H. Samarangenin B from Limonium sinense Suppresses Herpes Simplex Virus Type 1 Replication in Vero Cells by Regulation of Viral Macromolecular Synthesis. Antimicrob. Agents Chemother. 2002, 46, 2854-2864. [CrossRef]

81. Lin, L.-C.; Kuo, Y.-C.; Chou, C.-J. Anti-Herpes Simplex Virus Type-1 Flavonoids and a New Flavanone from the Root of Limonium sinense. Planta Medica 2000, 66, 333-336. [CrossRef]

82. Parida, M.; Upadhyay, C.; Pandya, G.; Jana, A. Inhibitory potential of neem (Azadirachta indica Juss) leaves on Dengue virus type-2 replication. J. Ethnopharmacol. 2002, 79, 273-278. [CrossRef]

83. Eze, D.C.; Okwor, E.C.; Ehirim, C.H.; Ibu, J.O.; Shoyinka, S.V.O. Comparative evaluation of Moringa oleifera and vacci-boost immuno-modulators in chickens experimentally infected with Newcastle Disease Virus (Kudu 113 Strain). South Asian J. Exp. Biol. 2014, 4, 42-47.

84. Murakami, A.; Kitazono, Y.; Jiwajinda, S.; Koshimizu, K.; Ohigashi, H. Niaziminin, a thiocarbamate from the leaves of Moringa oleifera, holds a strict structural requirement for inhibition of tumor-promotor-induced Epstein-Barr virus activation. Planta Med. 1998, 64, 319-323. [CrossRef] [PubMed]

85. Jayasundar, R.; Ghatak, S.; Makhdoomi, M.A.; Luthra, K.; Singh, A.; Velpandian, T. Challenges in integrating component level technology and system level information from Ayurveda: Insights from NMR phytometabolomics and anti-HIV potential of select Ayurvedic medicinal plants. J. Ayurveda Integr. Med. 2019, 10, 94-101. [CrossRef] [PubMed]

86. Vickers, N.J. Animal Communication: When I'm Calling You, Will You Answer Too? Curr. Biol. 2017, 27, R713-R715. [CrossRef] [PubMed]

87. Beula, J.M.; Gnanadesigan, M.; Rajkumar, P.B.; Ravikumar, S.; Anand, M. Antiviral, antioxidant and toxicological evaluation of mangrove plant from South East coast of India. Asian Pac. J. Trop. Biomed. 2012, 2, S352-S357. [CrossRef]

88. Lau, K.M.; Lee, K.M.; Koon, C.M.; Cheung, C.S.; Lau, C.P.; Ho, H.M.; Lee, M.Y.; Au, S.W.; Cheng, C.H.; Lau, C.B.; et al. Immunomodulatory and anti-SARS activities of Houttuynia cordata. J. Ethnopharmacol. 2008, 118, 79-85. [CrossRef] [PubMed]

89. Tolo, F.M.; Rukunga, G.M.; Muli, F.W.; Njagi, E.N.; Njue, W.; Kumon, K.; Mungai, G.M.; Muthaura, C.N.; Muli, J.M.; Keter, L.K.; et al. Anti-viral activity of the extracts of a Kenyan medicinal plant Carissa edulis against herpes simplex virus. J. Ethnopharmacol. 2006, 104, 92-99. [CrossRef]

90. Demurtas, O.C.; Massa, S.; Illiano, E.; De Martinis, D.; Chan, P.K.; Di Bonito, P.; Franconi, R. Antigen production in plant to tackle infectious diseases flare up: The case of SARS. Front. Plant. Sci. 2016, 7, 54. [CrossRef]

91. Van Der Meer, F.J.U.M.; De Haan, C.A.M.; Schuurman, N.M.P.; Haijema, B.J.; Verheije, M.H.; Bosch, B.J.; Balzarini, J.; Egberink, H.F. The carbohydrate-binding plant lectins and the non-peptidic antibiotic pradimicin A target the glycans of the coronavirus envelope glycoproteins. J. Antimicrob. Chemother. 2007, 60, 741-749. [CrossRef]

92. Notka, F.; Meier, G.; Wagner, R. Concerted inhibitory activities of Phyllanthus amarus on HIV replication in vitro and ex vivo. Antivir. Res. 2004, 64, 93-102. [CrossRef]

93. Das Mahapatra, A.; Bhowmik, P.; Banerjee, A.; Das, A.; Ojha, D.; Chattopadhyay, D. Ethnomedicinal Wisdom. In New Look to Phytomedicine; Elsevier: Amsterdam, The Netherlands, 2019; pp. 35-61.

94. Mukherjee, H.; Ojha, D.; Bag, P.; Chandel, H.S.; Bhattacharyya, S.; Chatterjee, T.K.; Mukherjee, P.K.; Chakraborti, S.; Chattopadhyay, D. Anti-herpes virus activities of Achyranthes aspera: An Indian ethnomedicine, and its triterpene acid. Microbiol. Res. 2013, 168, 238-244. [CrossRef]

95. Chen, C.-N.; Lin, C.P.C.; Huang, K.-K.; Chen, W.-C.; Hsieh, H.-P.; Liang, P.-H.; Hsu, J.T.-A. Inhibition of SARS-CoV 3C-like Protease Activity by Theaflavin-3,3'-digallate (TF3). Evid. Based Complement. Altern. Med. 2005, 2, 209-215. [CrossRef]

96. Arthanari, S.K.; Vanitha, J.; Ganesh, M.; Venkateshwaran, K.; Clercq, D. Evaluation of antiviral and cytotoxic activities of methanolic extract of S. grandiflora (Fabaceae) flowers. Asian Pac. J. Trop. Biomed. 2012, 2, S855-S858. [CrossRef] 
97. Cagno, V.; Civra, A.; Kumar, R.; Pradhan, S.; Donalisio, M.; Sinha, B.N.; Ghosh, M.; Lembo, D. Ficus religiosa L. bark extracts inhibit human rhinovirus and respiratory syncytial virus infection in vitro. J. Ethnopharmacol. 2015, 176, 252-257. [CrossRef]

98. Jain, M.; Ganju, L.; Katiyal, A.; Padwad, Y.; Mishra, K.; Chanda, S.; Karan, D.; Yogendra, K.; Sawhney, R. Effect of Hippophae rhamnoides leaf extract against Dengue virus infection in human blood-derived macrophages. Phytomedicine 2008, 15, 793-799. [CrossRef]

99. Yamai, M.; Tsumura, K.; Kimura, M.; Fukuda, S.; Murakami, T.; Kimura, Y. Antiviral Activity of a Hot Water Extract of Black Soybean against a Human Respiratory Illness Virus. Biosci. Biotechnol. Biochem. 2003, 67, 1071-1079. [CrossRef]

100. Mishra, S.; Aeri, V.; Gaur, P.K.; Jachak, S.M. Phytochemical, Therapeutic, and Ethnopharmacological Overview for a Traditionally Important Herb: Boerhavia diffusa Linn. BioMed. Res. Int. 2014, 2014, 808302. [CrossRef]

101. Keyaerts, E.; Vijgen, L.; Pannecouque, C.; Van Damme, E.; Peumans, W.; Egberink, H.; Balzarini, J.; Van Ranst, M. Plant lectins are potent inhibitors of coronaviruses by interfering with two targets in the viral replication cycle. Antivir. Res. 2007, 75, 179-187. [CrossRef]

102. Prathapan, A.; Vineetha, V.P.; Abhilash, P.A.; Raghu, K.G. Boerhaaviadiffusa, L. attenuates angiotensin II-induced hypertrophy in $\mathrm{H} 9 \mathrm{c} 2$ cardiac myoblast cells via modulating oxidative stress and down-regulating NF- $\mathrm{\beta} \beta$ and transforming growth factor $\beta 1$. Br. J. Nutr. 2013, 110, 1201-1210. [CrossRef]

103. Khan, M.Y.; Kumar, V. Mechanism \& inhibition kinetics of bioassay-guided fractions of Indian medicinal plants and foods as ACE inhibitors. J. Tradit. Complement. Med. 2019, 9, 73-84. [CrossRef]

104. Olivieri, F.; Prasad, V.; Valbonesi, P.; Srivastava, S.; Ghosal-Chowdhury, P.; Barbieri, L.; Bolognesi, A.; Stirpe, F. A systemic antiviral resistance-inducing protein isolated fromClerodendrum inermeGaertn. is a polynucleotide:adenosine glycosidase (ribosome-inactivating protein). FEBS Lett. 1996, 396, 132-134. [CrossRef]

105. Mukherjee, P.K.; Maity, N.; Nema, N.K.; Sarkar, B.K. Standardized Clitoria ternatea leaf extract as hyaluronidase, elastase and matrix-metalloproteinase-1 inhibitor. Indian J. Pharmacol. 2012, 44, 584-587. [CrossRef]

106. Bigoniya, P.; Patel, K.K.; Pandey, A.; Raj, V. Pharmacological screening of Coriandrum sativum Linn. for hepatoprotective activity. J. Pharm. Bioallied Sci. 2011, 3, 435-441. [CrossRef]

107. Vimalanathan, S.; Ignacimuthu, S.; Hudson, J.B. Medicinal plants of Tamil Nadu (Southern India) are a rich source of antiviral activities. Pharm. Biol. 2009, 47, 422-429. [CrossRef]

108. Gilani, A.H.; Khan, A.-U.; Raoof, M.; Ghayur, M.N.; Siddiqui, B.; Vohra, W.; Begum, S. Gastrointestinal, selective airways and urinary bladder relaxant effects of Hyoscyamus niger are mediated through dual blockade of muscarinic receptors and Ca2+channels. Fundam. Clin. Pharmacol. 2008, 22, 87-99. [CrossRef]

109. He, L.; Qi, Y.; Rong, X.; Jiang, J.; Yang, Q.; Yamahara, J.; Murray, M.; Li, Y. The Ayurvedic MedicineSalacia oblongaAttenuates Diabetic Renal Fibrosis in Rats: Suppression of Angiotensin II/AT1 Signaling. Evid. Based Complement. Altern. Med. 2011, 2011, 807451. [CrossRef]

110. Ganjhu, R.K.; Mudgal, P.P.; Maity, H.; Dowarha, D.; Devadiga, S.; Nag, S.; Arunkumar, G. Herbal plants and plant preparations as remedial approach for viral diseases. Virus Dis. 2015, 26, 225-236. [CrossRef] [PubMed]

111. Galani, V.J.; Patel, B.G.; Rana, D.G. Sphaeranthus indicus Linn.: A phytopharmacological review. Int. J. Ayurveda Res. 2010, 1, 247-253. [CrossRef] [PubMed]

112. Tiwari, B.K.; Khosa, R.L. Hepatoprotective and antioxidant effect of Sphaeranthus indicus against acetaminophen-induced hepatotoxicity in rats. J. Pharm Sci Res. 2009, 1, 26-30.

113. Tsai, Y.-C.; Lee, C.-L.; Yen, H.-R.; Chang, Y.-S.; Lin, Y.-P.; Huang, S.-H.; Lin, C.-W. Antiviral Action of Tryptanthrin Isolated from Strobilanthes cusia Leaf against Human Coronavirus NL63. Biomolecules 2020, 10, 366. [CrossRef]

114. Kumar, K.P.S.; Bhowmik, D.; Dutta, A.; Yadav, A.P.; Paswan, S.; Srivastava, S.; Deb, L. Recent trends in potential traditional Indian herbs Emblica officinalis and its medicinal importance. J. Pharmacogn. Phytochem. 2012, 1, 18-28.

115. Edai, Z.-C.; Fu, W.; Ewan, L.-Y.; Ecai, H.-H.; Ewang, N.; Qi, S.-S.; Du, D.-L. Different Growth Promoting Effects of Endophytic Bacteria on Invasive and Native Clonal Plants. Front. Plant Sci. 2016, 7, 706. [CrossRef]

116. Puri, A.; Saxena, R.P.; Saxena, K.; Srivastava, V.; Tandon, J. Immunostimulant activity of Nyctanthes arbor-tristis L. J. Ethnopharmacol. 1994, 42, 31-37. [CrossRef]

117. Ejantan, I.; Eahmad, W.; Ebukhari, S.N.A. Plant-derived immunomodulators: An insight on their preclinical evaluation and clinical trials. Front. Plant Sci. 2015, 6, 655. [CrossRef]

118. Mohammadi, S.; Jafari, B.; Asgharian, P.; Martorell, M.; Sharifi-Rad, J. Medicinal plants used in the treatment of Malaria: A key emphasis to Artemisia, Cinchona, Cryptolepis and Tabebuia genera. Phytother. Res. 2020, 34, 1556-1569. [CrossRef]

119. Brattig, N.; Diao, G.-J.; Berg, P. Immunoenhancing effect of flavonoid compounds on lymphocyte proliferation and immunoglobulin synthesis. Int. J. Immunopharmacol. 1984, 6, 205-215. [CrossRef]

120. Yadav, V.S.; Mishra, K.P.; Singh, D.P.; Mehrotra, S.; Singh, V.K. Immunomodulatory Effects of Curcumin. Immunopharmacol. Immunotoxicol. 2005, 27, 485-497. [CrossRef]

121. Fürst, R.; Zündorf, I. Plant-Derived Anti-Inflammatory Compounds: Hopes and Disappointments regarding the Translation of Preclinical Knowledge into Clinical Progress. Mediat. Inflamm. 2014, 2014, 146832. [CrossRef]

122. Ložienė, K.; Švedienè, J.; Paškevičius, A.; Raudonienè, V.; Sytar, O.; Kosyan, A. Influence of plant origin natural $\alpha$-pinene with different enantiomeric composition on bacteria, yeasts and fungi. Fitoterapia 2018, 127, 20-24. [CrossRef] 
123. Lecher, J.C.; Diep, N.; Krug, P.W.; Hilliard, J.K. Genistein Has Antiviral Activity against Herpes B Virus and Acts Synergistically with Antiviral Treatments to Reduce Effective Dose. Viruses 2019, 11, 499. [CrossRef]

124. Malaguarnera, L. Influence of Resveratrol on the Immune Response. Nutrients 2019, 11, 946. [CrossRef]

125. Gupta, S.; Mishra, K.P.; Ganju, L. Broad-spectrum antiviral properties of andrographolide. Arch. Virol. 2017, 162, 611-623. [CrossRef]

126. Perricone, C.; Triggianese, P.; Bartoloni, E.; Cafaro, G.; Bonifacio, A.F.; Bursi, R.; Perricone, R.; Gerli, R. The anti-viral facet of anti-rheumatic drugs: Lessons from COVID-19. J. Autoimmun. 2020, 111, 102468. [CrossRef]

127. Parvez, M.K.; Rehman, T.; Alam, P.; Al-Dosari, M.S.; Alqasoumi, S.I.; Alajmi, M.F. Plant-derived antiviral drugs as novel hepatitis B virus inhibitors: Cell culture and molecular docking study. Saudi Pharm. J. 2019, 27, 389-400. [CrossRef] [PubMed]

128. Khan, F.; Sarker, M.R.; Ming, L.C.; Mohamed, I.N.; Zhao, C.; Sheikh, B.Y.; Tsong, H.F.; Rashid, M.A. Comprehensive Review on Phytochemicals, Pharmacological and Clinical Potentials of Gymnema sylvestre. Front. Pharmacol. 2019, 10, 1223. [CrossRef] [PubMed]

129. Liu, T.; Liu, X.; Li, W. Tetrandrine, a Chinese plant-derived alkaloid, is a potential candidate for cancer chemotherapy. Oncotarget 2016, 7, 40800-40815. [CrossRef] [PubMed]

130. Kim, E.; Kwak, J. Antiviral phenolic compounds from the whole plants of Zostera marina against influenza A virus. Planta Medica 2015, 81, PW_06. [CrossRef]

131. Naser, B.; Bodinet, C.; Tegtmeier, M.; Lindequist, U. Thuja occidentalis(Arbor vitae): A Review of its Pharmaceutical, Pharmacological and Clinical Properties. Evid. Based Complement. Altern. Med. 2005, 2, 69-78. [CrossRef]

132. Dabeek, W.M.; Marra, M.V. Dietary Quercetin and Kaempferol: Bioavailability and Potential Cardiovascular-Related Bioactivity in Humans. Nutrients 2019, 11, 2288. [CrossRef]

133. Andarwulan, N.; Batari, R.; Sandrasari, D.A.; Bolling, B.; Wijaya, H. Flavonoid content and antioxidant activity of vegetables from Indonesia. Food Chem. 2010, 121, 1231-1235. [CrossRef]

134. Lama-Muñoz, A.; Contreras, M.D.M.; Espínola, F.; Moya, M.; Romero, I.; Castro, E. Optimization of Oleuropein and Luteolin-7-OGlucoside Extraction from Olive Leaves by Ultrasound-Assisted Technology. Energies 2019, 12, 2486. [CrossRef]

135. Cahyono, B.; Ariani, J.; Failasufa, H.; Suzery, M.; Susanti, S.; Hadiyanto, H. Extraction of homologous compounds of curcuminoid isolated from temulawak (Curcuma xanthorriza Roxb.) plant. Rasayan J. Chem. 2019, 12, 7-13. [CrossRef]

136. Rosidi, A.; Khomsan, A.; Setiawan, B.I.; Riyadi, H.; Briawan, D. Antioxidant Potential of Temulawak (Curcuma xanthorrhiza roxb). Pak. J. Nutr. 2016, 15, 556-560. [CrossRef]

137. Salehi, B.; Fokou, P.V.T.; Sharifi-Rad, M.; Zucca, P.; Pezzani, R.; Martins, N.; Sharifi-Rad, J. The Therapeutic Potential of Naringenin: A Review of Clinical Trials. Pharmaceuticals 2019, 12, 11. [CrossRef]

138. Meirinhos, J.; Silva, B.M.; Valentão, P.; Seabra, R.M.; Pereira, J.A.; Dias, A.; Andrade, P.B.; Ferreres, F. Analysis and quantification of flavonoidic compounds from Portuguese olive (Olea Europaea L.) leaf cultivars. Nat. Prod. Res. 2005, 19, 189-195. [CrossRef]

139. Nicolì, F.; Negro, C.; Vergine, M.; Aprile, A.; Nutricati, E.; Sabella, E.; Miceli, A.; Luvisi, A.; De Bellis, L. Evaluation of Phytochemical and Antioxidant Properties of 15 Italian Olea europaea L. Cultivar Leaves. Molecules 2019, 24, 1998. [CrossRef]

140. Miean, K.H.; Mohamed, S. Flavonoid (Myricetin, Quercetin, Kaempferol, Luteolin, and Apigenin) Content of Edible Tropical Plants. J. Agric. Food Chem. 2001, 49, 3106-3112. [CrossRef]

141. De Maat, M.; Pijl, H.; Kluft, C.; Princen, H. Consumption of black and green tea has no effect on inflammation, haemostasis and endothelial markers in smoking healthy individuals. Eur. J. Clin. Nutr. 2000, 54, 757-763. [CrossRef]

142. De Oliveira, R.M.M. Quantification of catechins and caffeine from green tea (Camellia sinensis) infusions, extract, and ready-todrink beverages. Food Sci. Technol. 2012, 32, 163-166. [CrossRef]

143. Sanwal, S.K.; Yadav, R.K.; Singh, P.K.; Buragohain, J.; Verma, M.R. Gingerol content of different genotypes of ginger (Zingiber officinale). Indian J. Agric. Sci. 2010, 80, 258.

144. Li, L.-L.; Cui, Y.; Guo, X.-H.; Ma, K.; Tian, P.; Feng, J.; Wang, J.-M. Pharmacokinetics and Tissue Distribution of Gingerols and Shogaols from Ginger (Zingiber officinale Rosc.) in Rats by UPLC-Q-Exactive-HRMS. Molecules 2019, 24, 512. [CrossRef]

145. Lelešius, R.; Karpovaitè, A.; Mickienè, R.; Drevinskas, T.; Tiso, N.; Ragažinskienè, O.; Kubilienè, L.; Maruška, A.; Šalomskas, A. In vitro antiviral activity of fifteen plant extracts against avian infectious bronchitis virus. BMC Vet. Res. 2019, 15, 178. [CrossRef]

146. Dolzhenko, Y.; Bertea, C.M.; Occhipinti, A.; Bossi, S.; Maffei, M. UV-B modulates the interplay between terpenoids and flavonoids in peppermint (Mentha piperita L.). J. Photochem. Photobiol. B Biol. 2010, 100, 67-75. [CrossRef]

147. Fatih, B.; Madani, K.; Chibane, M.; Duez, P.; Brahmi, F.; Khodir, M.; Mohamed, C.; Pierre, D. Chemical Composition and Biological Activities of Mentha Species. In Aromatic and Medicinal Plants-Back to Nature; IntechOpen: London, UK, 2017. [CrossRef]

148. Porte, A.; Godoy, R. Chemical composition of Thymus vulgaris L. (Thyme) essential oil from the Rio de Janeiro state, Brazil. J. Serb. Chem. Soc. 2008, 73, 307-310. [CrossRef]

149. Gedikoğlu, A.; Sökmen, M.; Çivit, A. Evaluation of Thymus vulgaris and Thymbra spicata essential oils and plant extracts for chemical composition, antioxidant, and antimicrobial properties. Food Sci. Nutr. 2019, 7, 1704-1714. [CrossRef] [PubMed]

150. Puodziuniene, G.; Kairyte, V.; Janulis, V.; Razukas, A.; Barsteigiene, Z.; Ragažinskienè, O. Quantitative hplc estimation of flavonoids in showy tick trefoil (Desmodium canadense) herbs. Pharm. Chem. J. 2011, 45, 88-90. [CrossRef]

151. Batyuk, V.S.V.; Vasil'eva, L.N.; Chernobrovaya, N.V.; Komissarenko, N.F. Flavonoids of Desmodium canadense and their analgesic effect. Khim. Farm. Zh. 1987, 21, 63-67. 
152. Taylor, W.G.; Sutherland, D.H.; Richards, K.W. Soyasaponins and Related Glycosides of Desmodium canadense and Desmodium illinoense. Open Nat. Prod. J. 2009, 2, 59-67. [CrossRef]

153. Ma, X.; Zheng, C.; Hu, C.; Rahman, K.; Qin, L. The genus Desmodium (Fabaceae)-traditional uses in Chinese medicine, phytochemistry and pharmacology. J. Ethnopharmacol. 2011, 138, 314-332. [CrossRef]

154. Yang, J.-L.; Ha, T.-K.-Q.; Dhodary, B.; Pyo, E.; Nguyen-Ngoc, H.; Cho, H.; Kim, E.; Oh, W.K. Oleanane Triterpenes from the Flowers ofCamellia japonicaInhibit Porcine Epidemic Diarrhea Virus (PEDV) Replication. J. Med. Chem. 2015, 58, 1268-1280. [CrossRef]

155. Yang, J.-L.; Ha, T.K.Q.; Oh, W.K. Discovery of inhibitory materials against PEDV corona virus from medicinal plants. Jpn. J. Vet. Res. 2016, 64, S53-S63.

156. Azuma, C.M.; Dos Santos, F.C.S.; Lago, J.H.G. Flavonoids and fatty acids of Camellia japonica leaves extract. Rev. Bras. Farm. 2011, 21, 1159-1162. [CrossRef]

157. Itokawa, H.; Nakajima, H.; Ikuta, A.; Iitaka, Y. Two triterpenes from the flowers of Camellia japonica. Phytochemistry 1981, 20, 2539-2542. [CrossRef]

158. Kato, M.; Ashihara, H. Biosynthesis and Catabolism of Purine Alkaloids in Camellia Plants. Nat. Prod. Commun. 2008, 3, 1934578 0800300907. [CrossRef]

159. Karioti, A.; Bilia, A.R.; Skaltsa, H. Quercus ilex L.: A rich source of polyacylated flavonoid glucosides. Food Chem. 2010, 123, 131-142. [CrossRef]

160. Cheng, P.-W.; Huang, L.-T.; Chiang, L.-C.; Lin, C.-C. Antiviral effects of saikosaponins on human coronavirus $229 \mathrm{e}$ in vitro. Clin. Exp. Pharmacol. Physiol. 2006, 33, 612-616. [CrossRef]

161. Yang, F.; Dong, X.; Yin, X.; Wang, W.; You, L.; Ni, J. Radix Bupleuri: A Review of Traditional Uses, Botany, Phytochemistry, Pharmacology, and Toxicology. BioMed. Res. Int. 2017, 2017, 7597596. [CrossRef]

162. Hemalatha, S.; Kumar, M.; Prasad, S. A current update on the phytopharmacological aspects of Houttuynia cordata Thunb. Pharmacogn. Rev. 2014, 8, 22-35. [CrossRef]

163. Lin, C.-W.; Tsai, F.-J.; Tsai, C.-H.; Lai, C.-C.; Wan, L.; Ho, T.-Y.; Hsieh, C.-C.; Chao, P.-D.L. Anti-SARS coronavirus 3C-like protease effects of Isatis indigotica root and plant-derived phenolic compounds. Antivir. Res. 2005, 68, 36-42. [CrossRef]

164. Speranza, J.; Miceli, N.; Taviano, M.F.; Ragusa, S.; Kwiecien, I.; Szopa, A.; Ekiert, H. Isatis tinctoria L. (Woad): A Review of Its Botany, Ethnobotanical Uses, Phytochemistry, Biological Activities, and Biotechnological Studies. Plants 2020, 9, 298. [CrossRef]

165. Wang, L.; Zhang, X.-Q.; Yin, Z.-Q.; Wang, Y.; Ye, W.-C. Two New Amaryllidaceae Alkaloids from the Bulbs of Lycoris radiata. Chem. Pharm. Bull. 2009, 57, 610-611. [CrossRef]

166. Tian, Y.; Zhang, C.; Guo, M. Comparative Analysis of Amaryllidaceae Alkaloids from Three Lycoris Species. Molecules 2015, 20, 21854-21869. [CrossRef]

167. Shi, T.; Yue, Y.; Shi, M.; Chen, M.; Yang, X.; Wang, L. Exploration of Floral Volatile Organic Compounds in Six Typical Lycoris taxa by GC-MS. Plants 2019, 8, 422. [CrossRef]

168. Gong, S.J.; Su, X.J.; Yu, H.P.; Li, J.; Qin, Y.J.; Xu, Q.; Luo, W.-S. A study on anti-SARS-CoV 3CL protein of flavonoids from litchi chinensis sonn core. Chin. Pharmacol. 2008, 24, 699-700.

169. Jo, S.; Kim, S.; Shin, D.H.; Kim, M.-S. Inhibition of SARS-CoV 3CL protease by flavonoids. J. Enzym. Inhib. Med. Chem. 2020, 35, 145-151. [CrossRef] [PubMed]

170. Nimmanpipug, P.; Lee, V.S.; Wolschann, P.; Hannongbua, S. Litchi chinensis-derived terpenoid as anti-HIV-1 protease agent: Structural design from molecular dynamics simulations. Mol. Simul. 2009, 35, 673-680. [CrossRef]

171. Ibrahim, S.R.; Mohamed, G.A. Litchi chinensis: Medicinal uses, phytochemistry, and pharmacology. J. Ethnopharmacol. 2015, 174, 492-513. [CrossRef] [PubMed]

172. Kim, D.E.; Min, J.S.; Jang, M.S.; Lee, J.Y.; Shin, Y.S.; Park, C.M.; Song, J.H.; Kim, H.R.; Kim, S.; Jin, Y.-H.; et al. Natural BisBenzylisoquinoline Alkaloids-Tetrandrine, Fangchinoline, and Cepharanthine, Inhibit Human Coronavirus OC43 Infection of MRC-5 Human Lung Cells. Biomolecules 2019, 9, 696. [CrossRef] [PubMed]

173. Zhao, T.; Tang, H.; Xie, L.; Zheng, Y.; Ma, Z.; Sun, Q.; Li, X. Scutellaria baicalensis Georgi. (Lamiaceae): A review of its traditional uses, botany, phytochemistry, pharmacology and toxicology. J. Pharm. Pharmacol. 2019, 71, 1353-1369. [CrossRef]

174. Shojai, T.M.; Langeroudi, A.G.; Karimi, V.; Barin, A.; Sadri, N. The effect of Allium sativum (Garlic) extract on infectious bronchitis virus in specific pathogen free embryonic egg. Avicenna J. Phytomed. 2016, 6, 458.

175. Weber, N.D.; Andersen, D.O.; North, J.A.; Murray, B.K.; Lawson, L.D.; Hughes, B.G. In VitroVirucidal Effects of Allium sativum (Garlic) Extract and Compounds. Planta Med. 1992, 58, 417-423. [CrossRef]

176. Szychowski, K.A.; Binduga, U.E.; Rybczyńska-Tkaczyk, K.; Leja, M.L.; Gmiński, J. Cytotoxic effects of two extracts from garlic (Allium sativum L.) cultivars on the human squamous carcinoma cell line SCC-15. Saudi J. Biol. Sci. 2018, 25, 1703-1712. [CrossRef]

177. Pontin, M.; Bottini, R.; Burba, J.L.; Piccoli, P. Allium sativum produces terpenes with fungistatic properties in response to infection with Sclerotium cepivorum. Phytochemistry 2015, 115, 152-160. [CrossRef]

178. Shin, S.-W. In vitro Effects of Essential Oils from the Aerial Parts of Artemisia annua L. Against Antibiotic-Susceptible and-Resistant Strains of Salmenella typhimurium. Yakhak Hoeji 2007, 51, 355-360.

179. Nigam, M.; Atanassova, M.; Mishra, A.P.; Pezzani, R.; Devkota, H.P.; Plygun, S.; Salehi, B.; Setzer, W.N.; Sharifi-Rad, J. Bioactive Compounds and Health Benefits of Artemisia Species. Nat. Prod. Commun. 2019, 14, 19850354. [CrossRef] 
180. Li, W.; Moore, M.J.; Vasilieva, N.; Sui, J.; Wong, S.K.; Berne, M.A.; Somasundaran, M.; Sullivan, J.L.; Luzuriaga, K.; Greenough, T.C.; et al. Angiotensin-converting enzyme 2 is a functional receptor for the SARS coronavirus. Nature 2003, 426, 450-454. [CrossRef]

181. Bais, S.; Gill, N.S.; Rana, N.; Shandil, S. A Phytopharmacological Review on a Medicinal Plant: Juniperus communis. Int. Sch. Res. Not. 2014, 2014, 634723. [CrossRef]

182. Park, J.Y.; Kim, J.H.; Kwon, J.M.; Kwon, H.J.; Jeong, H.J.; Kim, Y.M. Dieckol, a SARS-CoV 3CL inhibitor, isolated from the edible brown algae Ecklonia cava. Phytochemistry 2013, 20, 2539-2542.

183. Van Damme, E.J.M.; Peumans, W.J.; Barre, A.; Rougé, P. Plant Lectins: A Composite of Several Distinct Families of Structurally and Evolutionary Related Proteins with Diverse Biological Roles. Crit. Rev. Plant Sci. 1998, 17, 575-692. [CrossRef]

184. Müller, W.E.; Renneisen, K.; Kreuter, M.H.; Schröder, H.C.; Winkler, I. The D-mannose-specific lectin from Gerardia savaglia blocks binding of human immunodeficiency virus type I to $\mathrm{H} 9$ cells and human lymphocytes in vitro. J. Acquir. Immune Defic. Syndr. 1988, 1, 453-458.

185. Hammar, L.; Eriksson, S.; Morein, B. Human Immunodeficiency Virus Glycoproteins: Lectin Binding Properties. AIDS Res. Hum. Retrovir. 1989, 5, 495-506. [CrossRef]

186. Hansen, J.-E.S.; Nielsen, C.; Heegaard, P.; Mathiesen, L.R.; Nielsen, J.O.; Nielsen, C. Correlation between carbohydrate structures on the envelope glycoprotein gp120 of.HIV-1 and HIV-2 and syncytium inhibition with lectins. AIDS 1989, 3, 635-642. [CrossRef]

187. Matsui, T.; Kobayashi, S.; Yoshida, O.; Ishii, S.-I.; Abe, Y.; Yamamoto, N. Effects of succinylated concanavalin A on infectivity and syncytial formation of human immunodeficiency virus. Med. Microbiol. Immunol. 1990, 179, 225-235. [CrossRef]

188. Balzarini, J.; Schols, D.; Neyts, J.; Van Damme, E.; Peumans, W.; De Clercq, E. Alpha-(1-3)- and alpha-(1-6)-D-mannose-specific plant lectins are markedly inhibitory to human immunodeficiency virus and cytomegalovirus infections in vitro. Antimicrob. Agents Chemother. 1991, 35, 410-416. [CrossRef]

189. Balzarini, J.; Neyts, J.; Schols, D.; Hosoya, M.; Van Damme, E.; Peumans, W.; De Clercq, E. The mannose-specific plant lectins from Cymbidium hybrid and Epipactis helleborine and the (N-acetylglucosamine)n-specific plant lectin from Urtica dioica are potent and selective inhibitors of human immunodeficiency virus and cytomegalovirus replication in vitro. Antivir. Res. 1992, 18, 191-207. [CrossRef]

190. Balzarini, J.; Hatse, S.; Vermeire, K.; Princen, K.; Aquaro, S.; Perno, C.-F.; De Clercq, E.; Egberink, H.; Mooter, G.V.; Peumans, W.; et al. Mannose-Specific Plant Lectins from the Amaryllidaceae Family Qualify as Efficient Microbicides for Prevention of Human Immunodeficiency Virus Infection. Antimicrob. Agents Chemother. 2004, 48, 3858-3870. [CrossRef] [PubMed]

191. Krokhin, O.; Li, Y.; Andonov, A.; Feldmann, H.; Flick, R.; Jones, S.; Stroeher, U.; Bastien, N.; Dasuri, K.V.N.; Cheng, K.; et al. Mass Spectrometric Characterization of Proteins from the SARS Virus. Mol. Cell. Proteom. 2003, 2, 346-356. [CrossRef]

192. Salehi, B.; Machin, L.; Monzote, L.; Sharifi-Rad, J.; Ezzat, S.M.; Salem, M.A.; Merghany, R.M.; El Mahdy, N.M.; Kılıç, C.S.; Sytar, O.; et al. Therapeutic Potential of Quercetin: New Insights and Perspectives for Human Health. ACS Omega 2020, 5, 11849-11872. [CrossRef] [PubMed]

193. Coppé, J.-P.; Desprez, P.-Y.; Krtolica, A.; Campisi, J. The Senescence-Associated Secretory Phenotype: The Dark Side of Tumor Suppression. Annu. Rev. Pathol. Mech. Dis. 2010, 5, 99-118. [CrossRef]

194. Guerrero, L.; Castillo, J.; Quiñones, M.; Garcia-Vallvé, S.; Arola, L.; Pujadas, G.; Muguerza, B. Inhibition of Angiotensin-Converting Enzyme Activity by Flavonoids: Structure-Activity Relationship Studies. PLoS ONE 2012, 7, e49493. [CrossRef] [PubMed]

195. Wu, W.; Li, R.; Li, X.; He, J.; Jiang, S.; Liu, S.; Yang, J. Quercetin as an Antiviral Agent Inhibits Influenza A Virus (IAV) Entry. Viruses 2015, 8, 6. [CrossRef]

196. Häckl, L.; Cuttle, G.; Dovichi, S.S.; Lima-Landman, M.; Nicolau, M. Inhibition of Angiotensin-Converting Enzyme by Quercetin Alters the Vascular Response to Bradykinin and Angiotensin I. Pharmacology 2002, 65, 182-186. [CrossRef]

197. Thaler, R.; Maurizi, A.; Roschger, P.; Sturmlechner, I.; Khani, F.; Spitzer, S.; Rumpler, M.; Zwerina, J.; Karlic, H.; Dudakovic, A.; et al. Anabolic and Antiresorptive Modulation of Bone Homeostasis by the Epigenetic Modulator Sulforaphane, a Naturally Occurring Isothiocyanate. J. Biol. Chem. 2016, 291, 6754-6771. [CrossRef]

198. Olesin, E.; Nayar, R.; Saikumar-Lakshmi, P.; Berg, L.J. The Transcription Factor Runx2 Is Required for Long-Term Persistence of Antiviral CD8+ Memory T Cells. ImmunoHorizons 2018, 2, 251-261. [CrossRef]

199. Müller, L.; Meyer, M.; Bauer, R.N.; Zhou, H.; Zhang, H.; Jones, S.; Robinette, C.; Noah, T.L.; Jaspers, I. Effect of Broccoli Sprouts and Live Attenuated Influenza Virus on Peripheral Blood Natural Killer Cells: A Randomized, Double-Blind Study. PLoS ONE 2016, 11, e0147742. [CrossRef]

200. Marinella, M.A. Indomethacin and resveratrol as potential treatment adjuncts for SARS-CoV-2/COVID-19. Int. J. Clin. Pract. 2020, 74, e13535. [CrossRef]

201. Medina-Bolivar, F.; Condori, J.; Rimando, A.M.; Hubstenberger, J.; Shelton, K.; O'Keefe, S.F.; Bennett, S.; Dolan, M.C. Production and secretion of resveratrol in hairy root cultures of peanut. Phytochemistry 2007, 68, 1992-2003. [CrossRef]

202. Zhao, Q.; Chen, X.; Martin, C. Scutellaria baicalensis, the golden herb from the garden of Chinese medicinal plants. Sci. Bull. 2016, 61, 1391-1398. [CrossRef]

203. Sowndhararajan, K.; Deepa, P.; Kim, M.; Park, S.J.; Kim, S. Neuroprotective and Cognitive Enhancement Potentials of Baicalin: A Review. Brain Sci. 2018, 8, 104. [CrossRef]

204. Yonesi, M.; Rezazadeh, A. Plants as a prospective source of natural anti-viral compounds and oral vaccines against COVID-19 coronavirus. Preprints 2020. [CrossRef] 
205. Liu, H.; Ye, F.; Sun, Q.; Liang, H.; Li, C.; Li, S.; Lu, R.; Huang, B.; Tan, W.; Lai, L. Scutellaria baicalensis extract and baicalein inhibit replication of SARS-CoV-2 and its 3C-like protease in vitro. J. Enzym. Inhib. Med. Chem. 2021, 36, 497-503. [CrossRef] [PubMed]

206. Shah, S.L.; Wahid, F.; Khan, N.; Farooq, U.; Shah, A.J.; Tareen, S.; Ahmad, F.; Khan, T. Inhibitory Effects ofGlycyrrhiza glabraand Its Major Constituent Glycyrrhizin on Inflammation-Associated Corneal Neovascularization. Evid. Based Complement. Altern. Med. 2018, 2018, 8438101. [CrossRef] [PubMed]

207. Pilcher, H. Liquorice may tackle SARS. Nature 2003. [CrossRef]

208. Chen, H.; Du, Q. Potential natural compounds for preventing SARS-CoV-2 (2019-nCoV) infection. Preprints 2020. [CrossRef]

209. Dubey, K.; Dubey, R. Computation screening of narcissoside a glycosyloxyflavone for potential novel coronavirus 2019 (COVID-19) inhibitor. Biomed. J. 2020, 43, 363-367. [CrossRef]

210. Akram, M.; Shahab-Uddin, A.A.; Usmanghani, K.; Hannan, A.; Mohiuddin, E.; Asif, M. Curcuma longa and curcumin: A review article. Rom. J. Biol Plant. Biol 2010, 55, 65-70.

211. Hewlings, S.J.; Kalman, D.S. Curcumin: A Review of Its Effects on Human Health. Foods 2017, 6, 92. [CrossRef]

212. Praditya, D.; Kirchhoff, L.; Brüning, J.; Rachmawati, H.; Steinmann, J.; Steinmann, E. Anti-infective Properties of the Golden Spice Curcumin. Front. Microbiol. 2019, 10, 912. [CrossRef]

213. Rein, M.J.; Renouf, M.; Cruz-Hernandez, C.; Actis-Goretta, L.; Thakkar, S.K.; Da Silva Pinto, M. Bioavailability of bioactive food compounds: A challenging journey to bioefficacy. Br. J. Clin. Pharmacol. 2013, 75, 588-602. [CrossRef]

214. Bansal, T.; Awasthi, A.; Jaggi, M.; Khar, R.K.; Talegaonkar, S. Pre-clinical evidence for altered absorption and biliary excretion of irinotecan (CPT-11) in combination with quercetin: Possible contribution of P-glycoprotein. Life Sci. 2008, 83, 250-259. [CrossRef]

215. Shoba, G.; Joy, D.; Joseph, T.; Majeed, M.; Rajendran, R.; Srinivas, P.S.S.R. Influence of Piperine on the Pharmacokinetics of Curcumin in Animals and Human Volunteers. Planta Med. 1998, 64, 353-356. [CrossRef]

216. Basu, P.; Dutta, S.; Begum, R.; Mittal, S.; Das Dutta, P.; Bharti, A.C.; Panda, C.K.; Biswas, J.; Dey, B.; Talwar, G.P.; et al. Clearance of cervical human papillomavirus infection by topical application of curcumin and curcumin containing polyherbal cream: A phase II randomized controlled study. Asian Pac. J. Cancer Prev. 2013, 14, 5753-5759. [CrossRef]

217. Lobo, V.; Patil, A.; Phatak, A.; Chandra, N. Free radicals, antioxidants and functional foods: Impact on human health. Pharmacogn. Rev. 2010, 4, 118-126. [CrossRef]

218. Utomo, R.Y.; Meiyanto, E. Revealing the potency of citrus and galangal constituents to halt SARS-CoV-2 infection. Preprints 2020. [CrossRef]

219. Del Rio, D.; Stewart, A.J.; Mullen, W.; Burns, J.; Lean, M.E.J.; Brighenti, A.F.; Crozier, A. HPLC-MSnAnalysis of Phenolic Compounds and Purine Alkaloids in Green and Black Tea. J. Agric. Food Chem. 2004, 52, 2807-2815. [CrossRef]

220. Lucas, L.; Russell, A.; Keast, R. Molecular Mechanisms of Inflammation. Anti-Inflammatory Benefits of Virgin Olive Oil and the Phenolic Compound Oleocanthal. Curr. Pharm. Des. 2011, 17, 754-768. [CrossRef]

221. Remely, M.; Ferk, F.; Sterneder, S.; Setayesh, T.; Kepcija, T.; Roth, S.; Noorizadeh, R.; Greunz, M.; Rebhan, I.; Wagner, K.-H.; et al. Vitamin E Modifies High-Fat Diet-Induced Increase of DNA Strand Breaks, and Changes in Expression and DNA Methylation of Dnmt1 and MLH1 in C57BL/6J Male Mice. Nutrients 2017, 9, 607. [CrossRef]

222. Kaihatsu, K.; Yamabe, M.; Ebara, Y. Antiviral Mechanism of Action of Epigallocatechin-3-O-gallate and Its Fatty Acid Esters. Molecules 2018, 23, 2475. [CrossRef]

223. Ehrhardt, C.; Hrincius, E.R.; Korte, V.; Mazur, I.; Droebner, K.; Poetter, A.; Dreschers, S.; Schmolke, M.; Planz, O.; Ludwig, S. A polyphenol rich plant extract, CYSTUS052, exerts anti influenza virus activity in cell culture without toxic side effects or the tendency to induce viral resistance. Antivir. Res. 2007, 76, 38-47. [CrossRef]

224. Barak, V.; Halperin, T.; Kalickman, I. The effect of Sambucol, a black elderberry-based, natural product, on the production of human cytokines: I. Inflammatory cytokines. Eur. Cytokine Netw. 2001, 12, 290-296.

225. Efferth, T.; Romero, M.R.; Wolf, D.G.; Stamminger, T.; Marin, J.J.G.; Marschall, M. The Antiviral Activities of Artemisinin and Artesunate. Clin. Infect. Dis. 2008, 47, 804-811. [CrossRef] [PubMed]

226. Karamoddini, M.K.; Emami, S.A.; Ghannad, M.S.; Sani, E.A.; Sahebkar, A. Antiviral activities of aerial subsets of Artemisia species against Herpes Simplex virus type 1 (HSV1) in vitro. Asian Biomed. 2011, 5, 63-68. [CrossRef]

227. Khan, M.A.A.; Jain, D.; Bhakuni, R.; Zaim, M.; Thakur, R. Occurrence of some antiviral sterols in Artemisia annua. Plant Sci. 1991, 75, 161-165. [CrossRef]

228. Ferreira, J.F.; Luthria, D.L.; Sasaki, T.; Heyerick, A. Flavonoids from Artemisia annua L. as Antioxidants and Their Potential Synergism with Artemisinin against Malaria and Cancer. Molecules 2010, 15, 3135-3170. [CrossRef] [PubMed]

229. Day, B.J. Antioxidants as Potential Therapeutics for Lung Fibrosis. Antioxid. Redox Signal. 2008, 10, 355-370. [CrossRef]

230. Wang, C.; Xuan, X.; Yao, W.; Huang, G.; Jin, J. Anti-profibrotic effects of artesunate on bleomycin-induced pulmonary fibrosis in Sprague Dawley rats. Mol. Med. Rep. 2012, 12, 1291-1297. [CrossRef]

231. Roberfroid, M.B. Inulin-Type Fructans: Functional Food Ingredients. J. Nutr. 2007, 137, 2493S-2502S. [CrossRef]

232. Sanchez, M.; Lodi, F.; Vera, R.; Villar, I.C.; Cogolludo, A.; Jimenez, R.; Moreno, L.; Romero, M.; Tamargo, J.; Perez-Vizcaino, F.; et al. Quercetin and Isorhamnetin Prevent Endothelial Dysfunction, Superoxide Production, and Overexpression of p47phox Induced by Angiotensin II in Rat Aorta. J. Nutr. 2007, 137, 910-915. [CrossRef]

233. Chen, L.; Li, J.; Luo, C.; Liu, H.; Xu, W.; Chen, G.; Liew, O.W.; Zhu, W.; Puah, C.M.; Shen, X.; et al. Binding interaction of quercetin-3- $\beta$-galactoside and its synthetic derivatives with SARS-CoV 3CLpro: Structure-activity relationship studies reveal salient pharmacophore features. Bioorg. Med. Chem. 2006, 14, 8295-8306. [CrossRef] 
234. Okhuaroboa, A.; Falodun, J.E.; Erharuyicd, O.; Imiejec, V.; Faloduncde, A.; Langerc, P. Harnessing the medicinal properties of Andrographis paniculata for diseases and beyond: A review of its phytochemistry and pharmacology. Asian Pac. J. Trop. Dis. 2014, 4, 213-222. [CrossRef]

235. Yarnell, E. Herbs for Viral Respiratory Infections. Altern. Complement. Ther. 2018, 24, 35-43. [CrossRef]

236. Arora, R.; Chawla, R.; Marwah, R.; Arora, P.; Sharma, R.K.; Kaushik, V.; Goel, R.; Kaur, A.; Silambarasan, M.; Tripathi, R.P.; et al. Potential of Complementary and Alternative Medicine in Preventive Management of Novel H1N1 Flu (Swine Flu) Pandemic: Thwarting Potential Disasters in the Bud. Evid. Based Complement. Altern. Med. 2010, 2011, 586506. [CrossRef]

237. Coon, J.T.; Ernst, E. Andrographis paniculata in the treatment and prevention of upper respiratory tract infection (URTI): A systematic review of safety and efficacy. Focus Altern. Complement. Ther. 2010, 8, 160-161. [CrossRef]

238. Liu, Y.-T.; Chen, H.-W.; Lii, C.-K.; Jhuang, J.-H.; Huang, C.-S.; Li, M.-L.; Yao, H.-T. A Diterpenoid, 14-Deoxy-11, 12Didehydroandrographolide, in Andrographis paniculata Reduces Steatohepatitis and Liver Injury in Mice Fed a High-Fat and High-Cholesterol Diet. Nutrients 2020, 12, 523. [CrossRef]

239. Liu, Z.; Xiao, X.; Wei, X.; Li, J.; Yang, J.; Tan, H.; Zhu, J.; Zhang, Q.; Wu, J.; Liu, L. Composition and divergence of coronavirus spike proteins and host ACE2 receptors predict potential intermediate hosts of SARS-CoV-2. J. Med Virol. 2020, 92, 595-601. [CrossRef]

240. Mpiana, P.T.; Ngbolua, K.-T.-N.; Tshibangu, D.S.T.; Kilembe, J.T.; Gbolo, B.Z.; Mwanangombo, D.T.; Inkoto, C.L.; Lengbiye, E.M.; Mbadiko, C.M.; Matondo, A.; et al. Aloe vera (L.) Burm. F. as a Potential Anti-COVID-19 Plant: A Mini-review of Its Antiviral Activity. Eur. J. Med. Plants 2020, 86-93. [CrossRef]

241. Velthuis, A.J.W.T.; Worm, S.H.E.V.D.; Sims, A.C.; Baric, R.S.; Snijder, E.J.; Van Hemert, M.J. Zn2+ Inhibits Coronavirus and Arterivirus RNA Polymerase Activity In Vitro and Zinc Ionophores Block the Replication of These Viruses in Cell Culture. PLoS Pathog. 2010, 6, e1001176. [CrossRef]

242. Mohammadi, E.; Golchin, M. High protection of mice against Brucella abortus by oral immunization with recombinant probiotic Lactobacillus casei vector vaccine, expressing the outer membrane protein OMP19 of Brucella species. Comp. Immunol. Microbiol. Infect. Dis. 2020, 70, 101470. [CrossRef]

243. Chang, H.-C.; Hung, W.-C.; Huang, M.-S.; Hsu, H.-K. Extract from the Leaves of Toona sinensis Roemor Exerts Potent Antiproliferative Effect on Human Lung Cancer Cells. Am. J. Chin. Med. 2002, 30, 307-314. [CrossRef]

244. Yang, H.-L.; Chang, W.-H.; Chia, Y.-C.; Huang, C.-J.; Lu, F.-J.; Hsu, H.-K.; Hseu, Y.-C. Toona sinensis extracts induces apoptosis via reactive oxygen species in human premyelocytic leukemia cells. Food Chem. Toxicol. 2006, 44, 1978-1988. [CrossRef]

245. Wang, P.-H.; Tsai, M.-J.; Hsu, C.-Y.; Wang, C.-Y.; Hsu, H.-K.; Weng, C.-F. Toona sinensis Roem (Meliaceae) leaf extract alleviates hyperglycemia via altering adipose glucose transporter 4. Food Chem. Toxicol. 2008, 46, 2554-2560. [CrossRef]

246. Chen, C.-J.; Michaelis, M.; Hsu, H.-K.; Tsai, C.-C.; Yang, K.D.; Wu, Y.-C.; Cinatl, J.; Doerr, H.W. Toona sinensis Roem tender leaf extract inhibits SARS coronavirus replication. J. Ethnopharmacol. 2008, 120, 108-111. [CrossRef]

247. Qin, G.-W.; Xu, R.-S. Recent advances on bioactive natural products from Chinese medicinal plants. Med. Res. Rev. 1998, 18, 375-382. [CrossRef]

248. Wu, X.; Qin, G.; Cheung, K.K.; Cheng, K.F. New alkaloids from Isatis indigotica. Tetrahedron 1997, 53, 13323-13328. [CrossRef]

249. McGovern, S.L.; Shoichet, B.K. Information Decay in Molecular Docking Screens against Holo, Apo, and Modeled Conformations of Enzymes. J. Med. Chem. 2003, 46, 2895-2907. [CrossRef] [PubMed]

250. Andersen, D.O.; Weber, N.D.; Wood, S.G.; Hughes, B.G.; Murray, B.K.; North, J.A. In vitro virucidal activity of selected anthraquinones and anthraquinone derivatives. Antivir. Res. 1991, 16, 185-196. [CrossRef]

251. Mak, N.-K.; Leung, C.-Y.; Wei, X.-Y.; Shen, X.-L.; Wong, R.N.-S.; Leung, K.-N.; Fung, M.-C. Inhibition of RANTES expression by indirubin in influenza virus-infected human bronchial epithelial cells. Biochem. Pharmacol. 2004, 67, 167-174. [CrossRef]

252. Roy, S.; Bhattacharyya, P. Possible role of traditional medicinal plant Neem (Azadirachta indica) for the management of COVID-19 infection. Int. J. Res. Pharm. Sci. 2020, 11, 122-125. [CrossRef]

253. Xu, Z.; Shi, L.; Wang, Y.; Zhang, J.; Huang, L.; Zhang, C.; Liu, S.; Zhao, P.; Liu, H.; Zhu, L.; et al. Pathological findings of COVID-19 associated with acute respiratory distress syndrome. Lancet Respir. Med. 2020, 8, 420-422. [CrossRef]

254. Sujarwo, W.; Keim, A.P.; Caneva, G.; Toniolo, C.; Nicoletti, M. Ethnobotanical uses of neem (Azadirachta indica A. Juss.; Meliaceae) leaves in Bali (Indonesia) and the Indian subcontinent in relation with historical background and phytochemical properties. $J$. Ethnopharmacol. 2016, 189, 186-193. [CrossRef]

255. Thakurta, P.; Bhowmik, P.; Mukherjee, S.; Hajra, T.K.; Patra, A.; Bag, P.K. Antibacterial, antisecretory and antihemorrhagic activity of Azadirachta indica used to treat cholera and diarrhea in India. J. Ethnopharmacol. 2007, 111, 607-612. [CrossRef] [PubMed]

256. Bandyopadhyay, U.; Biswas, K.; Chatterjee, R.; Bandyopadhyay, D.; Chattopadhyay, I.; Ganguly, C.K.; Chakraborty, T.; Bhattacharya, K.; Banerjee, R.K. Gastroprotective effect of Neem (Azadirachta indica) bark extract: Possible involvement of $\mathrm{H}^{+}-\mathrm{K}^{+}-$ ATPase inhibition and scavenging of hydroxyl radical. Life Sci. 2002, 71, 2845-2865. [CrossRef]

257. Alam, G.; Wahyuono, S.; Ganjar, I.G.; Hakim, L.; Timmerman, H.; Verpoorte, R. Tracheospasmolytic Activity of Viteosin-A and Vitexicarpin Isolated fromVitex trifolia. Planta Med. 2002, 68, 1047-1049. [CrossRef] [PubMed]

258. Vellingiri, B.; Jayaramayya, K.; Iyer, M.; Narayanasamy, A.; Govindasamy, V.; Giridharan, B.; Ganesan, S.; Venugopal, A.; Venkatesan, D.; Ganesan, H.; et al. COVID-19: A promising cure for the global panic. Sci. Total. Environ. 2020, $725,138277$. [CrossRef] 
259. Dashputre, N.L.; Naikwade, N.S. Immunomodulatory activity of Abutilon indicum linn on albino mice. Int J. Pharm Sci Res. 2010, $1,178-184$.

260. Grover, A.; Agrawal, V.; Shandilya, A.; Bisaria, V.S.; Sundar, D. Non-nucleosidic inhibition of Herpes simplex virus DNA polymerase: Mechanistic insights into the anti-herpetic mode of action of herbal drug withaferin A. BMC Bioinform. 2011, 12, S22. [CrossRef]

261. Mehta, P.; McAuley, D.F.; Brown, M.; Sanchez, E.; Tattersall, R.S.; Manson, J.J. COVID-19: Consider cytokine storm syndromes and immunosuppression. Lancet 2020, 395, 1033-1034. [CrossRef]

262. Mohan, C.; Dinakar, S.; Anand, T.; Elayaraja, R.; SathiyaPriya, B. Phytochemical, GC-MS analysis and Antibacterial activity of a Medicinal Plant Acalypha indica. Int. J. Pharm. Tech. Res. 2012, 4, 1050-1054.

263. Dhaarani, V.; Sarvalingam, A.; Rajendran, A. Medicinal uses of psammophytic plants in Tranquebar regions of Tamil Nadu, India. J. Herbs Spices Med. Plants 2018, 24, 282-292. [CrossRef]

264. Premila, M.; Conboy, L. Ayurvedic Herbs: A Clinical Guide to the Healing Plants of Traditional Indian Medicine. J. Altern. Complement. Med. 2007, 13, 841-842. [CrossRef]

265. Vaghasiya, Y.; Chanda, S. Screening of some traditionally used Indian plants for antibacterial activity against Klebsiella pneumonia. J. Herb Med. Toxicol. 2009, 3, 161-164.

266. Kundu, S.; Roy, S.; Lyndem, L.M. Cassia alata L.: Potential role as anthelmintic agent against Hymenolepis diminuta. Parasitol. Res. 2012, 111, 1187-1192. [CrossRef]

267. Singh, R.P.; Jain, D.A. Evaluation of antimicrobial activity of alcoholic and aqueous extracts of five plants used in traditional medicine in North India. Int. J. Pharm. Tech. Res. 2011, 3, 376-380.

268. Nayak, V.; Jadhav, V.; Sajjanshetty, M.R. Traditional medicine in the management of Recurrent Tonsillitis-An Ayurvedic Perspective. J. Ayurveda Integr. Med Sci. 2017, 2, 98-106. [CrossRef]

269. Harwansh, R.K.; Pareta, S.K.; Patra, K.C.; Rahman, M.A. Preliminary phytochemical screening and anthelmintic activity of Chloroxylon swietenia root extract. Int. J. Phytomed. 2010, 2, 255-259.

270. Jacob, L.; Latha, M.S. In vitro antioxidant activity of Clitoria ternatea Linn. Int. J. Res. Phytochem. Pharmacol. 2013, 3, 35-39.

271. Dharmananda, S. Tibetan herbal medicine. Int. J. Orient. Med. 2011, 26, 1-13.

272. Boothapandi, M.; Ramanibai, R. Immunomodulatory activity of Indigofera tinctoria leaf extract on in vitro macrophage responses and lymphocyte proliferation. Int. J. Pharm. Pharm. Sci. 2016, 8, 58-63.

273. Afzal, U.; Gulfraz, M.; Hussain, S.; Malik, F.; Maqsood, S.; Shah, I.; Mahmood, S. Hepatoprotective effects of Justicia adhatoda L. against carbon tetrachloride (CCl4) induced liver injury in Swiss albino mice. Afr. J. Pharm. Pharmacol. 2013, 7, 8-14. [CrossRef]

274. John, K.M.; Enkhtaivan, G.; Ayyanar, M.; Jin, K.; Yeon, J.B.; Kim, D.H. Screening of ethnic medicinal plants of South India against influenza (H1N1) and their antioxidant activity. Saudi J. Biol. Sci. 2015, 22, 191-197. [CrossRef]

275. Kaur, A.; Katoch, D.; Singh, B.; Arora, S. Seclusion of vasicine-and quinazoline alkaloid from bioactive fraction of Justicia adhathoda and its antioxidant, antimutagenic and anticancerous activities. J. Glob. Biosci. 2016, 5, 3836-3850.

276. Ravindran, R.; Juliet, S.; Sunil, A.; Kumar, K.A.; Nair, S.N.; Amithamol, K.; Shynu, M.; Rawat, A.K.S.; Ghosh, S. Eclosion blocking effect of ethanolic extract of Leucas aspera (Lamiaceae) on Rhipicephalus (Boophilus) annulatus. Vet. Parasitol. 2011, 179, 287-290. [CrossRef]

277. Thenmozhi, M.; Dhanalakshmi, M.; Devi, K.M.; Sushila, K.; Thenmozhi, S. Evaluation of hepatoprotective activity of Leucas aspera hydroalcoholic leaf extract during exposure to lead acetate in male albino Wistar rats. Asian J. Pharm Clin. Res. 2013, 6, 78-81.

278. Kalita, N.; Kalita, M.C. Ethnomedicinal plants of Assam, India as an alternative source of future medicine for treatment of Pneumonia. Int. Res. J. 2014, 3, 76-82.

279. Sureshkumar, S.; Mishra, S. Hepatoprotective effect of extracts from Pergularia daemia Forsk. J. Ethnopharmacol. 2006, 107, 164-168. [CrossRef] [PubMed]

280. Naika, R.; Prasanna, K.P.; Ganapathy, P.S. Antibacterial activity of piperlongumine an alkaloid isolated from methanolic root extract of Piper Longum, L. Pharmacophore 2010, 1, 141-148.

281. Vadakkan, K.; Hemapriya, J.; Selvaraj, V. Quorum quenching intervened in vivo attenuation and immunological clearance enhancement by Solanum torvum root extract against Pseudomonas aeruginosa instigated pneumonia in Sprague Dawley rats. Clin. Phytosci. 2019, 5, 24. [CrossRef]

282. Abdel-Rahman, M.K.; Abd El-Megeid, A.A. Hepatoprotective effect of soapworts (Saponaria officinalis), pomegranate peel (Punica granatum $\mathrm{L}$ ) and cloves (Syzygium aromaticum linn) on mice with CCl4 hepatic intoxication. World J. Chem. 2006, 1, 41-46.

283. Mishra, A.; Kumar, S.; Pandey, A.K. Scientific Validation of the Medicinal Efficacy of Tinospora cordifolia. Sci. World J. 2013, 2013, 292934. [CrossRef]

284. Tharakan, B.; Dhanasekaran, M.; Manyam, B.V. Antioxidant and DNA protecting properties of anti-fatigue herb Trichopus zeylanicus. Phytotherapy Res. 2005, 19, 669-673. [CrossRef] [PubMed]

285. More, D.; Shetty, V.; Shah, A.; Mungekar, S.; Kamat, S.K.; Rege, N.N. Effects of polyherbal ayurvedic formulations on non-specific immunity: An experimental study. Indian J. Pharmacol. 2008, 40, S160-S171.

286. Koh, E.M.; Kim, H.J.; Kim, S.; Choi, W.H.; Choi, Y.H.; Ryu, S.Y.; Kim, Y.S.; Koh, W.S.; Park, S.-Y. Modulation of Macrophage Functions by Compounds Isolated from Zingiber officinale. Planta Med. 2008, 75, 148-151. [CrossRef] 
287. Chang, J.S.; Wang, K.C.; Yeh, C.F.; Shieh, D.E.; Chiang, L.C. Fresh ginger (Zingiber officinale) has anti-viral activity against human respiratory syncytial virus in human respiratory tract cell lines. J. Ethnopharmacol. 2013, 145, 146-151. [CrossRef]

288. Akoachere, J.-F.T.K.; Ndip, R.N.; Chenwi, E.B.; Ndip, L.M.; Njock, T.E.; Anong, D.N. Antibacterial effect of Zingiber officinale and Garcinia kola on respiratory tract pathogens. East Afr. Med. J. 2002, 79, 588-592. [CrossRef]

289. Ali, T.; Shahbaz, B.; Suleri, A. Analysis of myths and realities of deforestation in Northwest Pakistan: Implications for forestry extension. Int. J. Agric. Biol. 2006, 8, 107-110.

290. Abbasi, A.M.; Iqbal, J.; Khan, M.A.; Shah, M.H. Health risk assessment and multivariate apportionment of trace metals in wild leafy vegetables from Lesser Himalayas, Pakistan. Ecotoxicol. Environ. Saf. 2013, 92, 237-244. [CrossRef]

291. Singh, G.D.; Kaiser, P.; Youssouf, M.S.; Singh, S.; Khajuria, A.; Koul, A.; Bani, S.; Kapahi, B.K.; Satti, N.K.; Suri, K.A.; et al. Inhibition of early and late phase allergic reactions by Euphorbia hirta L. Phytotherapy Res. 2006, 20, 316-321. [CrossRef]

292. Ko, F.-N.; Huang, T.-F.; Teng, C.-M. Vasodilatory action mechanisms of apigenin isolated from Apium graveolens in rat thoracic aorta. Biochim. Biophys. Acta Gen. Subj. 1991, 1115, 69-74. [CrossRef]

293. Khare, C.P. Indian Medicinal Plants: An Illustrated Dictionary; Springer: Berlin/Heidelberg, Germany, 2008.

294. Walter, T.M. Review of Acalypha indica Linn. in Traditional Siddha Medicine. 2007. Available online: https://www.academia. edu/1410079/Review_of_Review_of_Acalypha_indica_Linn_in_Traditional_Siddha_Acalypha_indica_Linn_in_Traditional_ Siddha_Medicine (accessed on 5 March 2021).

295. Hosseinzadeh, H.; Ghenaati, J. Evaluation of the antitussive effect of stigma and petals of saffron (Crocus sativus) and its components, safranal and crocin in guinea pigs. Fitoterapia 2006, 77, 446-448. [CrossRef]

296. Joshi, V.K.; Joshi, A.; Dhiman, K.S. The Ayurvedic Pharmacopoeia of India, development and perspectives. J. Ethnopharmacol. 2017, 197, 32-38. [CrossRef]

297. Hirata, N.; Naruto, S.; Inaba, K.; Itoh, K.; Tokunaga, M.; Iinuma, M.; Matsuda, H. Histamine Release Inhibitory Activity of Piper nigrum Leaf. Biol. Pharm. Bull. 2008, 31, 1973-1976. [CrossRef] [PubMed]

298. Naseri, M.K.; Yahyavi, H. Antispasmodic effect of Piper nigrum fruit hot water extract on rat ileum. Pak. J. Biol. Sci 2008, 11, 1492-1496. [PubMed]

299. Bharali, R.; Azad, M.R.H.; Tabassum, J. Chemopreventive Action of Boerhaavia Diffusa on DMDA-induced Skin Carcinogenesis in Mice. Indian J. Physiol. Pharmacol. 2003, 47, 459-464. [PubMed]

300. Simin, K.; Khaliq-Uz-Zaman, S.M.; Ahmad, V.U. Antimicrobial activity of seed extracts and bondenolide from Caesalpinia bonduc (L.) Roxb. Phytother. Res. 2001, 15, 437-440. [CrossRef]

301. Shinwari, Z.K. Medicinal plants research in Pakistan. J. Med. Plant. Res. 2010, 4, 161-176. [CrossRef]

302. Thwe, A.; Arasu, M.V.; Li, X.; Park, C.H.; Kim, S.J.; Al-Dhabi, N.A.; Park, S.U. Effect of Different Agrobacterium rhizogenes Strains on Hairy Root Induction and Phenylpropanoid Biosynthesis in Tartary Buckwheat (Fagopyrum tataricum Gaertn). Front. Microbiol. 2016, 7, 318. [CrossRef]

303. Shanmugavelu, M. Noikaluku Siddha parikaram. Part I; Indian Medicine-Homeopathy Department, Government of India: New Delhi, India, 2004.

304. Moineddin, R.; Nie, J.X.; Domb, G.; Leong, A.M.; Upshur, R.E.G. Seasonality of primary care utilization for respiratory diseases in Ontario: A time-series analysis. BMC Health Serv. Res. 2008, 8, 160. [CrossRef]

305. Srivastava, A.K.; Kumar, A.; Misra, N. On the Inhibition of COVID-19 Protease by Indian Herbal Plants: An in Silico Investigation. arXiv 2020, arXiv:2004.034112020.

306. Alsaffar, D.F. In Silico Molecular Docking Studies of Medicinal Arabic Plant-Based Bioactive Compounds as a Promising Drug Candidate against COVID-19. Int. J. Innov. Sci. Res. Technol. 2020, 5, 876-896.

307. Gautret, P.; Lagier, J.-C.; Parola, P.; Hoang, V.T.; Meddeb, L.; Sevestre, J.; Mailhe, M.; Doudier, B.; Aubry, C.; Amrane, S.; et al. Clinical and microbiological effect of a combination of hydroxychloroquine and azithromycin in 80 COVID-19 patients with at least a six-day follow up: A pilot observational study. Travel Med. Infect. Dis. 2020, 34, 101663. [CrossRef]

308. Juurlink, D.N. Safety considerations with chloroquine, hydroxychloroquine and azithromycin in the management of SARS-CoV-2 infection. Can. Med. Assoc. J. 2020, 192, E450-E453. [CrossRef]

309. Gurwitz, D. Angiotensin receptor blockers as tentative SARS-CoV-2 therapeutics. Drug Dev. Res. 2020, 81, 537-540. [CrossRef]

310. Shen, C.; Wang, Z.; Zhao, F.; Yang, Y.; Li, J.; Yuan, J.; Wang, F.; Li, D.; Yang, M.; Xing, L.; et al. Treatment of 5 Critically Ill Patients With COVID-19 With Convalescent Plasma. JAMA 2020, 323, 1582. [CrossRef]

311. Dhama, K.; Sharun, K.; Tiwari, R.; Dadar, M.; Malik, Y.S.; Singh, K.P.; Chaicumpa, W. COVID-19, an emerging coronavirus infection: Advances and prospects in designing and developing vaccines, immunotherapeutics, and therapeutics. Hum. Vaccines Immunother. 2020, 16, 1232-1238. [CrossRef]

312. Uddin, M.; Mustafa, F.; Rizvi, T.A.; Loney, T.; Al Suwaidi, H.; Al-Marzouqi, A.H.H.; Eldin, A.K.; Alsabeeha, N.; Adrian, T.E.; Stefanini, C.; et al. SARS-CoV-2/COVID-19: Viral Genomics, Epidemiology, Vaccines, and Therapeutic Interventions. Viruses 2020, 12, 526. [CrossRef]

313. Sanders, J.M.; Monogue, M.L.; Jodlowski, T.Z.; Cutrell, J.B. Pharmacologic Treatments for Coronavirus Disease 2019 (COVID-19). JAMA 2020, 323, 1824-1836. [CrossRef]

314. Menachery, V.D.; Gralinski, L.E.; Mitchell, H.D.; Dinnon, K.H.; Leist, S.R.; Yount, B.L.; McAnarney, E.T.; Graham, R.L.; Waters, K.M.; Baric, R.S. Combination Attenuation Offers Strategy for Live Attenuated Coronavirus Vaccines. J. Virol. 2018, 92. [CrossRef]

315. Fischer, R.; Buyel, J. Molecular farming-The slope of enlightenment. Biotechnol. Adv. 2020, 40, 107519. [CrossRef] 
316. Gleba, Y.; Klimyuk, V.; Marillonnet, S. Magnifection?a new platform for expressing recombinant vaccines in plants. Vaccine 2005, 23, 2042-2048. [CrossRef]

317. A Critical Review of the Concept of Transgenic Plants: Insights into Pharmaceutical Biotechnology and Molecular Farming. Curr. Issues Mol. Biol. 2016, 18, 21-42. [CrossRef]

318. Rosales-Mendoza, S. Will plant-made biopharmaceuticals play a role in the fight against COVID-19? Expert Opin. Biol. Ther. 2020, 20, 545-548. [CrossRef]

319. Malik, S. Production of Plant Derived Natural Compounds through Hairy Root Culture; Springer: Berlin/Heidelberg, Germany, 2017.

320. Grzegorczyk, I.; Królicka, A.; Wysokińska, H. Establishment of Salvia officinalis L. hairy root cultures for the production of rosmarinic acid. Z. Naturforschung C 2006, 61, 351-356. [CrossRef]

321. Tavassoli, P.; Afshar, A.S. Influence of different Agrobacterium rhizogenes strains on hairy root induction and analysis of phenolic and flavonoid compounds in marshmallow (Althaea officinalis L.). 3 Biotech 2018, 8, 351. [CrossRef]

322. Park, C.H.; Zhao, S.; Yeo, H.J.; Park, Y.E.; Baska, T.B.; Arasu, M.V.; Al-Dhabi, N.A.; Park, S.U. Comparison of Different Strains of Agrobacterium rhizogenes for Hairy Root Induction and Betulin and Betulinic Acid Production in Morus alba. Nat. Prod. Commun. 2017, 12, 1934578X1701200403. [CrossRef]

323. Yousefian, S.; Lohrasebi, T.; Farhadpour, M.; Haghbeen, K. Production of phenolic acids in hairy root cultures of medicinal plant Mentha spicata L. in response to elicitors. Mol. Biol. Res. Commun. 2020, 9, 23-34.

324. Gabr, A.; Sytar, O.; Ahmed, A.R.; Smetanska, I. Production of phenolic acid and antioxidant activity in transformed hairy root cultures of common buckwheat (Fagopyrum Esculentum M.). Aust. J. Basic Appl. Sci. 2012, 6, 577-586.

325. Zhou, Y.; Hirotani, M.; Yoshikawa, T.; Furuya, T. Flavonoids and phenylethanoids from hairy root cultures of Scutellaria baicalensis. Phytochemistry 1997, 44, 83-87. [CrossRef]

326. Skala, E.K.A.; Olszewska, M.A.; Kiss, A.K.; WysokiNska, H. Establishment of Hairy Root Cultures of Rhaponticum carthamoides (Willd.) Iljin for the Production of Biomass and Caffeic Acid Derivatives. BioMed Res. Int. 2015. [CrossRef]

327. Balasubramanian, M.; Anbumegala, M.; Surendran, R.; Arun, M.; Shanmugam, G. Elite hairy roots of Raphanus sativus (L.) as a source of antioxidants and flavonoids. 3 Biotech 2018, 8, 128. [CrossRef]

328. Thiruvengadam, M.; Praveen, N.; Kim, E.-H.; Kim, S.-H.; Chung, I.-M. Production of anthraquinones, phenolic compounds and biological activities from hairy root cultures of Polygonum multiflorum Thunb. Protoplasma 2014, 251, 555-566. [CrossRef]

329. Hosseini, S.M.; Bahramnejad, B.; Baneh, H.D.; Emamifar, A.; Goodwin, P.H. Hairy root culture optimization and resveratrol production from Vitis vinifera subsp. sylvesteris. World J. Microbiol. Biotechnol. 2017, 33, 67. [CrossRef] [PubMed]

330. Lee, S.-W.; Kim, Y.S.; Uddin, R.; Kwon, D.Y.; Kim, Y.B.; Lee, M.Y.; Kim, S.-J.; Park, S.U. Resveratrol Production from Hairy Root Cultures of Scutellaria baicalensis. Nat. Prod. Commun. 2013, 8, 1934578x1300800517. [CrossRef]

331. Ludwig-Müller, J.; Jahn, L.; Lippert, A.; Püschel, J.; Walter, A. Improvement of hairy root cultures and plants by changing biosynthetic pathways leading to pharmaceutical metabolites: Strategies and applications. Biotechnol. Adv. 2014, 32, 1168-1179. [CrossRef]

332. Halder, M.; Sarkar, S.; Jha, S. Elicitation: A biotechnological tool for enhanced production of secondary metabolites in hairy root cultures. Eng. Life Sci. 2019, 19, 880-895. [CrossRef]

333. Vasconsuelo, A.; Boland, R. Molecular aspects of the early stages of elicitation of secondary metabolites in plants. Plant Sci. 2007, 172, 861-875. [CrossRef]

334. Putalun, $\mathrm{W}$. Technology of compact MAb and its application for medicinal plant breeding named as missile type molecular breeding. Curr. Drug Discov. Technol. 2011, 8, 24-31. [CrossRef]

335. Hoseinpanahi, B.; Bahramnejad, B.; Majdi, M.; Dastan, D.; Ashengroph, M. The effect of different elicitors on hairy root biomass and resveratrol production in wild Vitis vinifera. Appl. Biotechnol. Rep. 2020, 7, 25-31. [CrossRef] 